\title{
Minimum Critical Values Study
}

\section{July 2005}

\author{
Prepared by \\ P. B. Fox \\ L. M. Petrie \\ C. M. Hopper
}

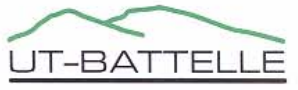

ORNL-27 (4-00) 


\section{DOCUMENT AVAILABILITY}

Reports produced after January 1, 1996, are generally available free via the U.S. Department of Energy (DOE) Information Bridge:

Web site: http://www.osti.gov/bridge

Reports produced before January 1, 1996, may be purchased by members of the public from the following source:

National Technical Information Service

5285 Port Royal Road

Springfield, VA 22161

Telephone: 703-605-6000 (1-800-553-6847)

TDD: 703-487-4639

Fax: 703-605-6900

E-mail: info@ntis.fedworld.gov

Web site: http://www.ntis.gov/support/ordernowabout.htm

Reports are available to DOE employees, DOE contractors, Energy Technology Data Exchange (ETDE) representatives, and International Nuclear Information System (INIS) representatives from the following source:

Office of Scientific and Technical Information

P.O. Box 62

Oak Ridge, TN 37831

Telephone: 865-576-8401

Fax: 865-576-5728

E-mail: reports@adonis.osti.gov

Web site: http://www.osti.gov/contact.html

This report was prepared as an account of work sponsored by an agency of the United States Government. Neither the United States government nor any agency thereof, nor any of their employees, makes any warranty, express or implied, or assumes any legal liability or responsibility for the accuracy, completeness, or usefulness of any information, apparatus, product, or process disclosed, or represents that its use would not infringe privately owned rights. Reference herein to any specific commercial product, process, or service by trade name, trademark, manufacturer, or otherwise, does not necessarily constitute or imply its endorsement, recommendation, or favoring by the United States Government or any agency thereof. The views and opinions of authors expressed herein do not necessarily state or reflect those of the United States Government or any agency thereof. 
Nuclear Science and Technology Division (94)

\title{
MINIMUM CRITICAL VALUES STUDY
}

P. B. Fox, L. M. Petrie, Jr., and C M. Hopper

Date Published-July 2005

\author{
Prepared by \\ OAK RIDGE NATIONAL LABORATORY \\ P.O. Box 2008 \\ Oak Ridge, Tennessee 37831-6283 \\ managed by \\ UT-BATTELLE, LLC \\ for the \\ U.S. DEPARTMENT OF ENERGY \\ under contract DE-AC05-00OR22725
}





\section{CONTENTS}

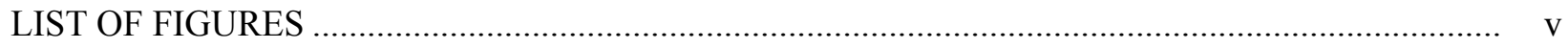

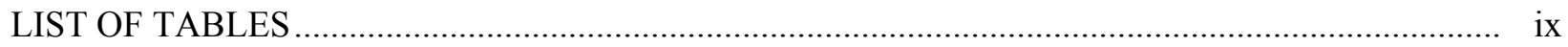

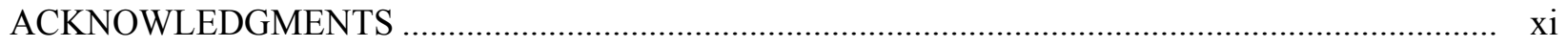

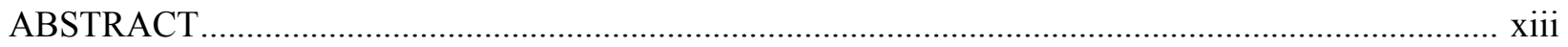

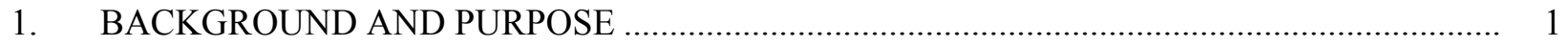

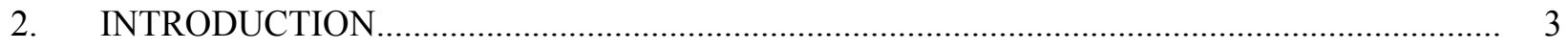

3. DESCRIPTION OF THE CODE PACKAGE …............................................................ 5

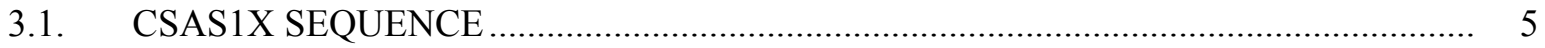

3.2. 238-GROUP NEUTRON CROSS-SECTION LIBRARY ….................................... 5

3.3. CALCULATION METHODS …................................................................... 5

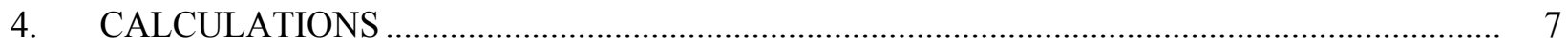

4.1. URANIUM OXIDE-WATER MIXTURES ............................................................. 7

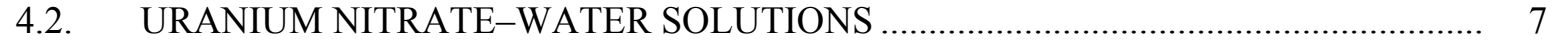

4.3. PLUTONIUM OXIDE-WATER MIXTURES ..................................................... 12

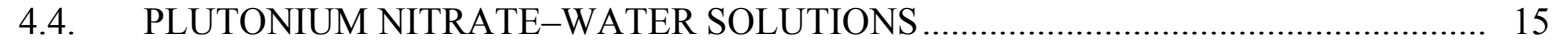

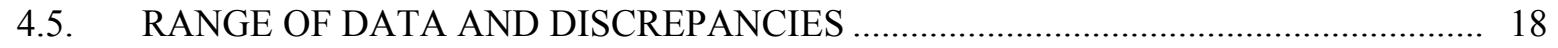

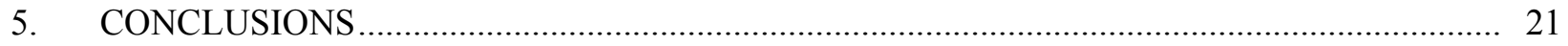

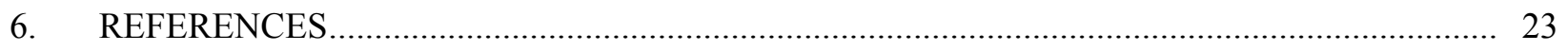

APPENDIX A. GRAPHS OF $\mathrm{UO}_{2}-\mathrm{H}_{2} \mathrm{O}$, WATER REFLECTED $(30 \mathrm{~cm})$ :

CRITICAL PARAMETERS vs FUEL VOLUME FRACTIONS ..................................................... 25

APPENDIX B. GRAPHS OF UNH- $\mathrm{H}_{2} \mathrm{O}$, WATER REFLECTED $(30 \mathrm{~cm})$ :

CRITICAL PARAMETERS vS URANIUM DENSITY

APPENDIX C. GRAPHS OF $\mathrm{PuO}_{2}-\mathrm{H}_{2} \mathrm{O}$, WATER REFLECTED $(30 \mathrm{~cm})$ :

CRITICAL PARAMETERS vs FUEL VOLUME FRACTIONS .

APPENDIX D. GRAPHS OF PuNH- $\mathrm{H}_{2} \mathrm{O}$, WATER REFLECTED $(30 \mathrm{~cm})$ : 



\section{LIST OF FIGURES}

Figure

Page

A.1 Radius vs volume fraction for $3 \%$ enriched $\mathrm{UO}_{2}-\mathrm{H}_{2} \mathrm{O}$ spheres.........................................27

A.2 Radius vs volume fraction for $4 \%$ enriched $\mathrm{UO}_{2}-\mathrm{H}_{2} \mathrm{O}$ spheres.........................................27

A.3 Radius vs volume fraction for $5 \%$ enriched $\mathrm{UO}_{2}-\mathrm{H}_{2} \mathrm{O}$ spheres..........................................28

A.4 Radius vs volume fraction for $20 \%$ enriched $\mathrm{UO}_{2}-\mathrm{H}_{2} \mathrm{O}$ spheres........................................28

A.5 Radius vs volume fraction for $100 \%$ enriched $\mathrm{UO}_{2}-\mathrm{H}_{2} \mathrm{O}$ spheres.....................................29

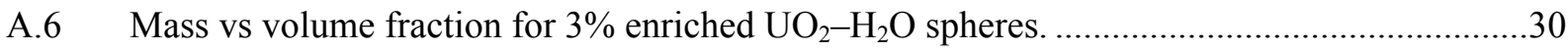

A.7 Mass vs volume fraction for $4 \%$ enriched $\mathrm{UO}_{2}-\mathrm{H}_{2} \mathrm{O}$ spheres. ...........................................30

A.8 Mass vs volume fraction for 5\% enriched $\mathrm{UO}_{2}-\mathrm{H}_{2} \mathrm{O}$ spheres...........................................

A.9 Mass vs volume fraction for $20 \%$ enriched $\mathrm{UO}_{2}-\mathrm{H}_{2} \mathrm{O}$ spheres. ......................................31

A.10 Mass vs volume fraction for $100 \%$ enriched $\mathrm{UO}_{2}-\mathrm{H}_{2} \mathrm{O}$ spheres. ........................................32

A.11 One-half thickness vs volume fraction for $3 \%$ enriched $\mathrm{UO}_{2}-\mathrm{H}_{2} \mathrm{O}$ slabs..............................33

A.12 One-half thickness vs volume fraction for $4 \%$ enriched $\mathrm{UO}_{2}-\mathrm{H}_{2} \mathrm{O}$ slabs..............................33

A.13 One-half thickness vs volume fraction for 5\% enriched $\mathrm{UO}_{2}-\mathrm{H}_{2} \mathrm{O}$ slabs..............................34

A.14 One-half thickness vs volume fraction for $20 \%$ enriched $\mathrm{UO}_{2}-\mathrm{H}_{2} \mathrm{O}$ slabs...........................34

A.15 One-half thickness vs volume fraction for $100 \%$ enriched $\mathrm{UO}_{2}-\mathrm{H}_{2} \mathrm{O}$ slabs..........................35

A.16 Radius vs volume fraction for $3 \%$ enriched $\mathrm{UO}_{2}-\mathrm{H}_{2} \mathrm{O}$ cylinders.......................................36

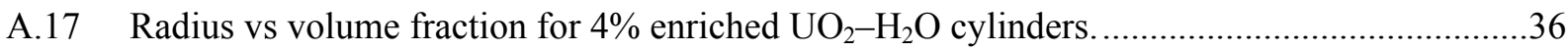

A.18 Radius vs volume fraction for $5 \%$ enriched $\mathrm{UO}_{2}-\mathrm{H}_{2} \mathrm{O}$ cylinders........................................37

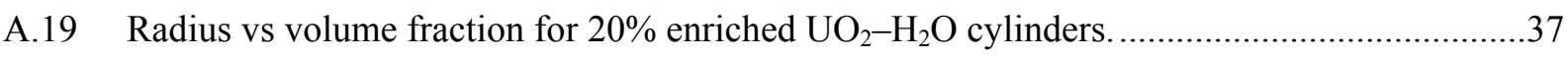

A.20 Radius vs volume fraction for $100 \%$ enriched $\mathrm{UO}_{2}-\mathrm{H}_{2} \mathrm{O}$ cylinders......................................38

B.1 Radius vs density and volume fraction for $3 \%$ enriched $\mathrm{UNH}-\mathrm{H}_{2} \mathrm{O}$ spheres. .......................41

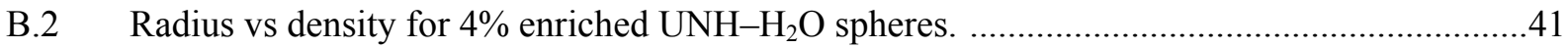

B.3 Radius vs density for $5 \%$ enriched $\mathrm{UNH}-\mathrm{H}_{2} \mathrm{O}$ spheres.....................................................42

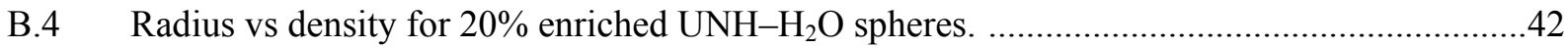




\section{LIST OF FIGURES (continued)}

Figure

Page

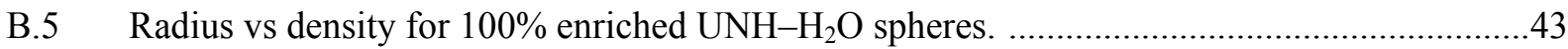

B.6 Mass vs density for $3 \%$ enriched $\mathrm{UNH}-\mathrm{H}_{2} \mathrm{O}$ spheres. ........................................................4

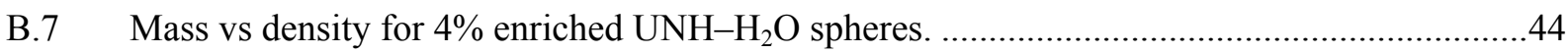

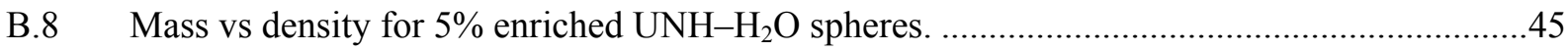

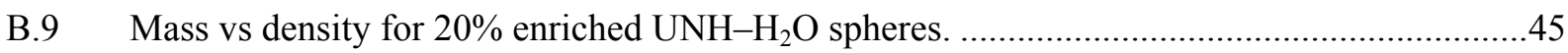

B.10 Mass vs density for $100 \%$ enriched $\mathrm{UNH}-\mathrm{H}_{2} \mathrm{O}$ spheres. ....................................................46

B.11 Radius vs density and volume fraction for $3 \%$ enriched $\mathrm{UNH}-\mathrm{H}_{2} \mathrm{O}$ slabs...........................47

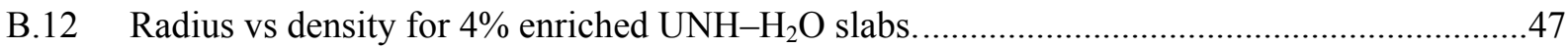

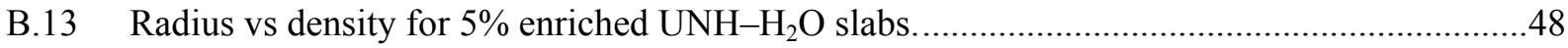

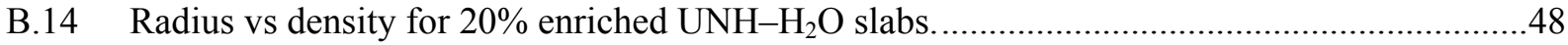

B.15 Radius vs density for $100 \%$ enriched $\mathrm{UNH}-\mathrm{H}_{2} \mathrm{O}$ slabs...................................................

B.16 Radius vs density and volume fraction for $3 \%$ enriched $\mathrm{UNH}-\mathrm{H}_{2} \mathrm{O}$ cylinders......................50

B.17 Radius vs density for $4 \%$ enriched $\mathrm{UNH}-\mathrm{H}_{2} \mathrm{O}$ cylinders. ...............................................50

B.18 Radius vs density for $5 \%$ enriched $\mathrm{UNH}-\mathrm{H}_{2} \mathrm{O}$ cylinders. .................................................

B.19 Radius vs density for $20 \%$ enriched $\mathrm{UNH}-\mathrm{H}_{2} \mathrm{O}$ cylinders. ..............................................51

B.20 Radius vs density for $100 \%$ enriched $\mathrm{UNH}-\mathrm{H}_{2} \mathrm{O}$ cylinders. .........................................52

C.1 Radius vs volume fraction for $100 \%$ enriched $\mathrm{PuO}_{2}-\mathrm{H}_{2} \mathrm{O}$ spheres. ...................................55

C.2 Radius vs volume fraction for $95 \%$ enriched $\mathrm{PuO}_{2}-\mathrm{H}_{2} \mathrm{O}$ spheres. ......................................55

C.3 Radius vs volume fraction for $90 \%$ enriched $\mathrm{PuO}_{2}-\mathrm{H}_{2} \mathrm{O}$ spheres. .....................................56

C.4 Radius vs volume fraction for $80 \%$ enriched $\mathrm{PuO}_{2}-\mathrm{H}_{2} \mathrm{O}$ spheres. .....................................56

C.5 Radius vs volume fraction for $71 \%$ enriched $\mathrm{PuO}_{2}-\mathrm{H}_{2} \mathrm{O}$ spheres. .....................................57

C.6 Mass vs volume fraction for $100 \%$ enriched $\mathrm{PuO}_{2}-\mathrm{H}_{2} \mathrm{O}$ spheres......................................58

C.7 Mass vs volume fraction for $95 \%$ enriched $\mathrm{PuO}_{2}-\mathrm{H}_{2} \mathrm{O}$ spheres..........................................58

C.8 Mass vs volume fraction for $90 \%$ enriched $\mathrm{PuO}_{2}-\mathrm{H}_{2} \mathrm{O}$ spheres.........................................59 


\section{LIST OF FIGURES (continued)}

Figure

$\underline{\text { Page }}$

C.9 Mass vs volume fraction for $80 \%$ enriched $\mathrm{PuO}_{2}-\mathrm{H}_{2} \mathrm{O}$ spheres.........................................59

C.10 Mass vs volume fraction for $71 \%$ enriched $\mathrm{PuO}_{2}-\mathrm{H}_{2} \mathrm{O}$ spheres..........................................60

C.11 Radius vs volume fraction for $100 \%$ enriched $\mathrm{PuO}_{2}-\mathrm{H}_{2} \mathrm{O}$ slabs. ..........................................61

C.12 Radius vs volume fraction for $95 \%$ enriched $\mathrm{PuO}_{2}-\mathrm{H}_{2} \mathrm{O}$ slabs. ........................................61

C.13 Radius vs volume fraction for $90 \%$ enriched $\mathrm{PuO}_{2}-\mathrm{H}_{2} \mathrm{O}$ slabs. ..........................................62

C.14 Radius vs volume fraction for $80 \%$ enriched $\mathrm{PuO}_{2}-\mathrm{H}_{2} \mathrm{O}$ slabs. .........................................62

C.15 Radius vs volume fraction for $71 \%$ enriched $\mathrm{PuO}_{2}-\mathrm{H}_{2} \mathrm{O}$ slabs. ..........................................63

C.16 Radius vs volume fraction for $100 \%$ enriched $\mathrm{PuO}_{2}-\mathrm{H}_{2} \mathrm{O}$ cylinders...................................64

C.17 Radius vs volume fraction for $95 \%$ enriched $\mathrm{PuO}_{2}-\mathrm{H}_{2} \mathrm{O}$ cylinders.....................................64

C.18 Radius vs volume fraction for $90 \%$ enriched $\mathrm{PuO}_{2}-\mathrm{H}_{2} \mathrm{O}$ cylinders.....................................65

C.19 Radius vs volume fraction for $80 \%$ enriched $\mathrm{PuO}_{2}-\mathrm{H}_{2} \mathrm{O}$ cylinders...................................65

C.20 Radius vs volume fraction for $71 \%$ enriched $\mathrm{PuO}_{2}-\mathrm{H}_{2} \mathrm{O}$ cylinders.....................................66

D.1 Radius vs density for $100 \%$ enriched $\mathrm{PuNH}-\mathrm{H}_{2} \mathrm{O}$ spheres. .................................................69

D.2 Radius vs density for $95 \%$ enriched $\mathrm{PuNH}-\mathrm{H}_{2} \mathrm{O}$ spheres. .................................................69

D.3 Radius vs density for $90 \%$ enriched $\mathrm{PuNH}-\mathrm{H}_{2} \mathrm{O}$ spheres. .................................................70

D.4 Radius vs density for $80 \%$ enriched $\mathrm{PuNH}-\mathrm{H}_{2} \mathrm{O}$ spheres. .................................................70

D.5 Radius vs density for $71 \%$ enriched $\mathrm{PuNH}-\mathrm{H}_{2} \mathrm{O}$ spheres. ................................................

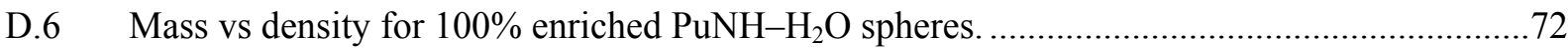

D.7 Mass vs density for $95 \%$ enriched $\mathrm{PuNH}-\mathrm{H}_{2} \mathrm{O}$ spheres. ....................................................

D.8 Mass vs density for $90 \%$ enriched $\mathrm{PuNH}-\mathrm{H}_{2} \mathrm{O}$ spheres. .................................................73

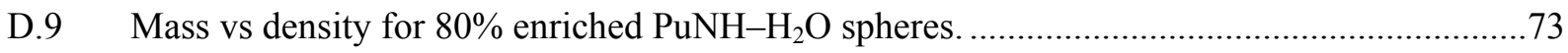

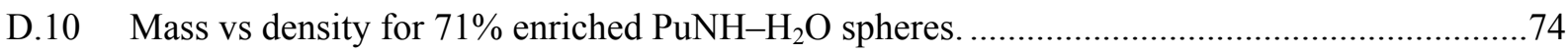

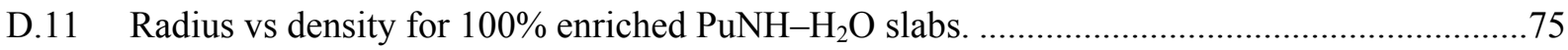

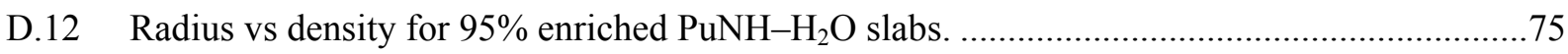




\section{LIST OF FIGURES (continued)}

Figure

Page

D.13 Radius vs density for $90 \%$ enriched $\mathrm{PuNH}-\mathrm{H}_{2} \mathrm{O}$ slabs. ....................................................76

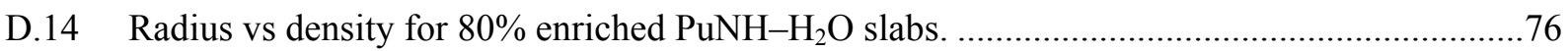

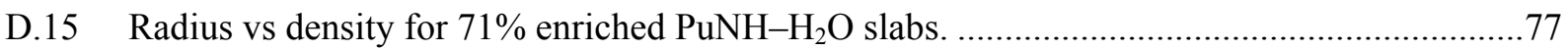

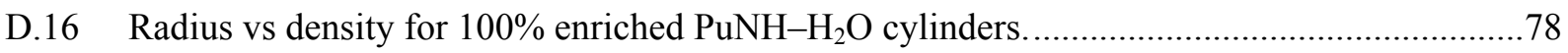

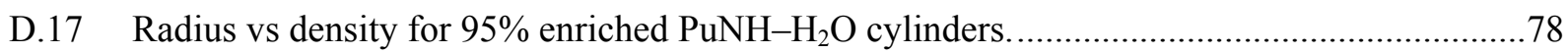

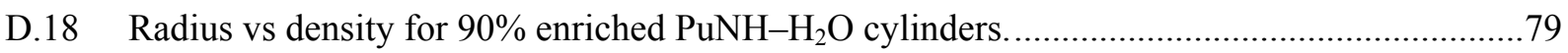

D.19 Radius vs density for $80 \%$ enriched $\mathrm{PuNH}-\mathrm{H}_{2} \mathrm{O}$ cylinders. ...................................................79

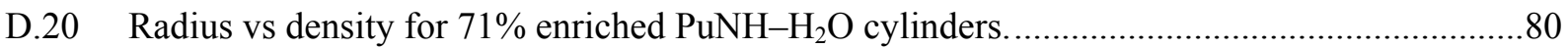




\section{LIST OF TABLES}

$\underline{\text { Table }}$

$\underline{\text { Page }}$

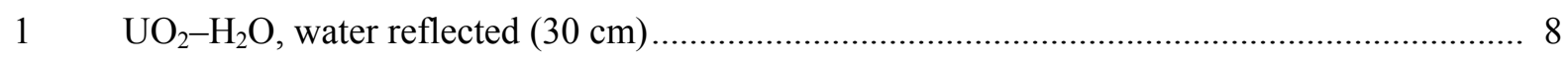

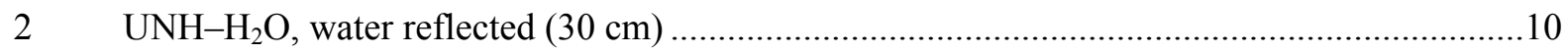

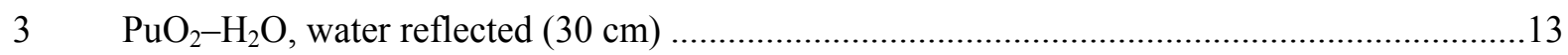

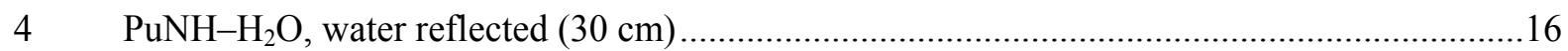

$5 \quad$ Spheres: largest and smallest minimum critical values and differences $\left(\Delta_{\text {all }}\right)$

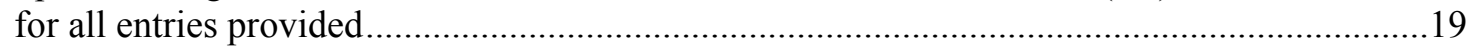

$6 \quad$ Cylinders and slabs: largest and smallest minimum critical values and differences

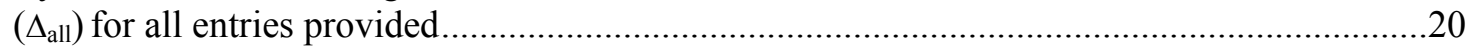





\section{ACKNOWLEDGMENTS}

This work was sponsored by the U.S. Department of Energy's Nuclear Criticality Safety Program under the project title "Applicable Ranges of Bounding Curves and Data" (AROBCAD). The authors are grateful for the technical reviews and comments provided by S. Goluoglu and R. M. Westfall. A special acknowledgment is extended to Willena C. Carter, Marsha Savage, Sarah Parker, and Debbie Weaver for their patient assistance in preparing this report. 



\begin{abstract}
This report provides minimum critical values for various 30-cm water-reflected uranium and plutonium oxide and nitrate aqueous mixtures as calculated by the SCALE CSAS1X sequence using the 238-group ENDF/B-V neutron cross-section library. The minimum values were determined through parametric searches in one-dimensional geometry.

The calculations have been performed to obtain the minimum values: critical volume and mass for spheres, critical radius for cylinders, critical thickness for slabs, and minimum critical concentration (infinite geometry) for the following homogenous mixtures:
\end{abstract}
1. $\mathrm{UO}_{2}-\mathrm{H}_{2} \mathrm{O}$ for $3,4,5,20$, and $100 \mathrm{wt} \%{ }^{235} \mathrm{U}$;
2. UNH for $3,4,5,20$, and $100 \mathrm{wt} \%{ }^{235} \mathrm{U}$;
3. $\mathrm{PuO}_{2}-\mathrm{H}_{2} \mathrm{O}$ for $100 / 0 / 0,95 / 5 / 0,90 / 5 / 5,80 / 10 / 10$, and $71 / 17 / 11 / 1$ wt $\%$ of ${ }^{239} \mathrm{Pu} /{ }^{240} \mathrm{Pu} /{ }^{241} \mathrm{Pu}\left(/^{242} \mathrm{Pu}\right)$; and
4. PuNH for $100 / 0 / 0,95 / 5 / 0,90 / 5 / 5,80 / 10 / 10$, and $71 / 17 / 11 / 1$ wt $\%$ of ${ }^{239} \mathrm{Pu} /{ }^{240} \mathrm{Pu} /{ }^{241} \mathrm{Pu}\left(/{ }^{242} \mathrm{Pu}\right)$.

All bounding surfaces were fully reflected by $30 \mathrm{~cm}$ of $\mathrm{H}_{2} \mathrm{O}$. 



\section{BACKGROUND AND PURPOSE}

For several decades, and on a national and international basis, minimum critical values of fissionable systems characteristic of those found in fuel cycle operations have been used in consensus standards as technical guidance for establishing safe operational limits. In the mid-1990s, the international criticality safety community recognized that it would be highly desirable to develop an international consensus on minimum critical values for a variety of simple systems fueled with uranium and plutonium. An effort was initiated through the Organization for Economic Cooperation and Development (OECD) Nuclear Science Committee to address the problem of developing this consensus. Six countries have participated in this effort, and the results contained in this document detail the contribution from the United States.

The current status of the international effort was reported at the Seventh International Conference on Nuclear Criticality, ICNC2003 (ref. 1). The material described below was excerpted from this report.

An OECD/NEA expert group has compiled international data on existing minimum critical values for $\mathrm{UO}_{2}, \mathrm{PuO}_{2}, \mathrm{UNH}$ and $\mathrm{PuNH}$ systems to identify significant discrepancies in the data and to propose explanations. Minimum critical values given by criticality handbooks and other sources are known to show discrepancies that are sometimes considerable. Being unique like physical constants, minimum critical values should be the same, nevertheless. This is important with regard to licensing, though minimum critical values are used primarily in connection with safety factors. These discrepancies were brought to the attention of the OECD/NEA Working Party for Nuclear Criticality Safety (WPNCS) who appointed an expert group to investigate the issue.

The expert group confined the investigation to homogeneous systems. The work started with the compilation of a quite large number of chemical compositions of U-235, U-233, and plutonium, all with different reflectors. With over 900 data entries, the analytical effort was too high. The group thus focused on aqueous systems of $\mathrm{UO}_{2}, \mathrm{PuO}_{2}$, uraniumnitrate and plutonium-nitrate, with five enrichments of uranium and six $\mathrm{Pu}$ vectors, respectively.

With this scope of investigation, the objectives of the expert group became to

- collect data from different countries, including a short description of the methods used to derive the data;

- identify discrepancies and propose explanations;

- address effects of engineering data, density formulae, and reflector material;

- provide technical input to the international community; and

- supply a general reference for criticality safety analyses that use/include minimum critical values.

The minimum system parameters established for the critical systems include the spherical mass ( $\mathrm{kg}$ of $\mathrm{U}$ or $\mathrm{Pu}$ ), the spherical volume (liters), and the diameter $(\mathrm{cm})$ and thickness $(\mathrm{cm})$ of the axially infinite cylinder and the infinite slab, as well as the minimum concentrations ( $\mathrm{g} U$ or Pu per liter) for fully infinite systems. Generally, the results submitted within the past 4 years agree to within $17 \%$ (spherical volume) for the nitrate-moderated systems. The $\mathrm{PuO}_{2}$ systems generally agree to within $10 \%$ (spherical mass). The low-enriched $\mathrm{UO}_{2}$ systems agree to within $19 \%$, but the agreement is worse for the more highly enriched systems [20\% enriched-33\% (spherical mass), 100\% enriched-36\% (spherical volume)]. The complete summary of these results is given in Table 5 of this report.

The work reported in this document was performed as a subtask of the Applicable Ranges of Bounding Curves and Data (AROBCAD) work element of the U.S. Department of Energy (DOE) 
Nuclear Criticality Safety Program. Again, it constitutes the contribution from the United States to this international comparison of minimum critical values. 


\section{INTRODUCTION}

The OECD/Nuclear Energy Agency (OECD/NEA) Nuclear Science Committee Working Party on Nuclear Criticality Safety formed the Expert Group on Minimum Critical Values. The goal of the first task was to prepare a database of minimum critical values (mass, volume, radius, slab thickness, concentration, enrichment) that are often used as a basis for criticality safety considerations. Calculations reported in this document were performed with the CSAS1X sequence in SCALE $^{2}$ (Standardized Computer Analyses for Licensing Evaluation) using the 238-group ENDF/B-V cross-section library ${ }^{3}$ to obtain the minimum critical values for the following homogenous mixtures:

$$
\begin{aligned}
& \text { 1. } \mathrm{UO}_{2}-\mathrm{H}_{2} \mathrm{O} \text { for } 3,4,5,20 \text {, and } 100 \mathrm{wt} \%{ }^{235} \mathrm{U} \text {; } \\
& \text { 2. } \mathrm{UNH} \text { [i.e., } \mathrm{UO}_{2}\left(\mathrm{NO}_{3}\right)_{2}+x \mathrm{H}_{2} \mathrm{O} \text { ] for } 3,4,5,20 \text {, and } 100 \mathrm{wt} \%{ }^{235} \mathrm{U} \text {; } \\
& \text { 3. } \mathrm{PuO}_{2}-\mathrm{H}_{2} \mathrm{O} \text { for } 100 / 0 / 0,95 / 5 / 0,90 / 5 / 5,80 / 10 / 10 \text {, and } \\
& 71 / 17 / 11 / 1 \text { wt } \% \text { of }{ }^{239} \mathrm{Pu} /{ }^{240} \mathrm{Pu} /{ }^{241} \mathrm{Pu}\left(/^{242} \mathrm{Pu}\right) \text {; and } \\
& \text { 4. } \mathrm{PuNH} \text { [i.e., } \mathrm{Pu}\left(\mathrm{NO}_{3}\right)_{4}+x \mathrm{H}_{2} \mathrm{O} \text { for } 100 / 0 / 0,95 / 5 / 0,90 / 5 / 5,80 / 10 / 10 \text {, and } \\
& 71 / 17 / 11 / 1 \text { wt } \% \text { of }{ }^{239} \mathrm{Pu} /{ }^{240} \mathrm{Pu} /{ }^{241} \mathrm{Pu}\left({ }^{242} \mathrm{Pu}\right) \text {. }
\end{aligned}
$$

All bounding surfaces were fully reflected by $30 \mathrm{~cm}$ of $\mathrm{H}_{2} \mathrm{O}$.

The computational biases for the computed critical systems reported herein were not determined. However, the reader is directed to Experience with the Scale Criticality Safety Cross-Section Libraries. ${ }^{4}$ The latter report provides insights into computational biases that have been observed with the use of the computational methods utilized for the development of the information in the present report. Relative to the determination of the nearly unique minimum critical values when nearly optimally moderated with light water, computational biases are well characterized. For nearly optimally moderated systems, the computed values of $\mathrm{k}_{\text {eff }}$ for critical systems are approximately $1.00 \pm 0.02,1.005 \pm 0.015,1.015 \pm 0.02$ for high-enriched, low-enriched, and plutonium systems, respectively. 



\section{DESCRIPTION OF THE CODE PACKAGE}

\subsection{CSAS1X SEQUENCE}

CSAS1X creates a microscopic cell-weighted library in the AMPX working library format. This control module sequentially activates the functional modules BONAMI and NITAWL-II to process the necessary cross sections and calculates the k-effective of the one-dimensional (1-D) problem using the discrete-ordinates code XSDRNPM. CSAS1X can perform a 1-D geometry search for these critical values: radius of sphere and cylinder, and slab thickness.

\subsection{8-GROUP NEUTRON CROSS-SECTION LIBRARY}

The 238-group ENDF/B-V library is a general-purpose criticality analysis library and is the most complete library available in SCALE. This library is also known as the LAW (Library to Analyze

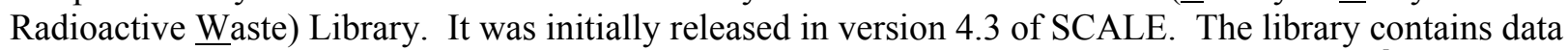
for all nuclides (more than 300) available in ENDF/B-V processed by the AMPX-77 system. ${ }^{5}$ It also contains data for ENDF/B-VI evaluations of ${ }^{14} \mathrm{~N},{ }^{15} \mathrm{~N},{ }^{16} \mathrm{O},{ }^{154} \mathrm{Eu}$, and ${ }^{155} \mathrm{Eu}$. The library has 148 fast groups and 90 thermal groups (below $3 \mathrm{eV}$ ).

Most resonance nuclides in the 238-group ENDF/B-V library have resonance data (to be processed by NITAWL-II) in the resolved-resonance range and Bondarenko factors (to be processed by BONAMI) for the unresolved range. This library contains resolved-resonance data for $s$-wave, $p$-wave, and $d$-wave resonances $(1=0,1=1$, and $1=2$, respectively). These data can have a significant effect on results for undermoderated, thermal, and intermediate-energy problems. Resonance structures in several light to intermediate-mass ENDF nuclides (i.e., ${ }^{7} \mathrm{Li},{ }^{19} \mathrm{~F},{ }^{27} \mathrm{Al},{ }^{28} \mathrm{Si}$ ) are accounted for using Bondarenko shielding factors. These structures can also be important in intermediate-energy problems. The ${ }^{235} \mathrm{U}$ ENDF/B-V data result in slightly too much fission, while the ${ }^{238} \mathrm{U}$ data result in slightly too much capture. Although better than the ENDF/B-IV data, the thermal-plutonium data still appear to have problems.

All nuclides in the 238-group LAW Library use the same weighting spectrum, consisting of

1. Maxwellian spectrum (peak at $300 \mathrm{~K}$ ) from $10^{-5}$ to $0.125 \mathrm{eV}$,

2. a $1 /$ E spectrum from $0.125 \mathrm{eV}$ to $67.4 \mathrm{keV}$,

3. a fission spectrum (effective temperature at $1.273 \mathrm{MeV}$ ) from $67.4 \mathrm{keV}$ to $10 \mathrm{MeV}$, and

4. a $1 / \mathrm{E}$ spectrum from 10 to $20 \mathrm{MeV}$.

The use of these spectra [as opposed to the $1 /\left(E \sigma_{t}\right)$ spectrum used to generate the 218-group library] makes it difficult to collapse a general-purpose broad-group library that is valid over a wide range of problems.

All nuclides use a $\mathrm{P}_{5}$ Legendre expansion to fit the elastic and discrete-level inelastic scattering processes in the fast range, thereby making the library suitable for both reactor and shielding applications. $\mathrm{A}_{3}$ fit was used for thermal scattering. Thermal scattering kernels are provided at temperatures $(\mathrm{K})$ as presented in Table M4.2.7 of the SCALE manual. All other scattering processes use $\mathrm{P}_{0}$ fits.

\subsection{CALCULATION METHODS}

The 238-group cross-section library and the CSAS1X sequences in SCALE were used to determine critical data for spheres, cylinders, and slabs. The discrete-ordinates code XSDRNPM was used to 
generate the calculated values. The XSDRNPM overall point convergence is $1.0 \mathrm{E}-06$, while the meshing is generated by SCALE. Cross sections were calculated with a temperature of $293 \mathrm{~K}$.

Default values in SCALE have been used whenever considered appropriate or when no other information is known. If SCALE generates a warning or error message suggesting changes to default parameters, the default values may be changed.

The compositions of the homogeneous uranium oxide-water mixture and the plutonium oxide-water mixture were calculated using available options in CSAS1X. The default density of $10.96 \mathrm{~g} / \mathrm{cm}^{3}$ was used for $\mathrm{UO}_{2}$, and $11.86 \mathrm{~g} / \mathrm{cm}^{3}$ was used for $\mathrm{PuO}_{2}$. The density of $\mathrm{H}_{2} \mathrm{O}$ was $0.9982 \mathrm{~g} / \mathrm{cm}^{3}$ for both mixtures.

The homogeneous uranium nitrate-water mixture and plutonium nitrate-water mixture were calculated using the built-in SCALE atomic number density equations for uranyl nitrate $\left[\mathrm{UO}_{2}\left(\mathrm{NO}_{3}\right)_{2}\right]$ solution and for plutonium nitrate $\left[\left(\mathrm{Pu}\left(\mathrm{NO}_{3}\right)_{4}\right]\right.$ solution per ARH-600 (ref. 6).

The equations for $\mathrm{UO}_{2}\left(\mathrm{NO}_{3}\right)_{2}$ solution are as follows:

$$
\begin{aligned}
& \rho_{\mathrm{UO}_{2}\left(\mathrm{NO}_{3}\right)_{2}}=\rho_{U}\left(A_{U}+8 A_{O}+2 A_{N}\right) / A_{U}, \\
& \rho_{\mathrm{HNO}_{3}}=M_{\mathrm{HNO}_{3}}\left(A_{H}+A_{N}+3 A_{O}\right) / 1000,
\end{aligned}
$$

and

$$
\begin{aligned}
\rho_{\text {soln }}= & {\left[\begin{array}{l}
1.0012+317.7 * \rho_{U} / A_{N U}+0.03096 * M_{\mathrm{HNO}_{3}}
\end{array}\right] } \\
& \left(1-5 \times 10^{-4} \Delta T\right)+1.45 \times 10^{-4} \Delta T .
\end{aligned}
$$

The equations for $\left(\mathrm{Pu}\left(\mathrm{NO}_{3}\right)_{4}\right.$ solution are as follows:

$$
\begin{gathered}
\rho_{\text {soln }}=0.9982 * \rho_{P_{U}} / A_{N_{P}}\left(1-0.3619 * \rho_{P_{U}}-0.0246 * M_{\mathrm{HNO}_{3}}\right) \\
+\rho_{P_{U}\left(\mathrm{NO}_{3}\right)_{4}}+\rho_{\mathrm{HNO}_{3}}, \\
\rho_{P_{U}\left(\mathrm{NO}_{3}\right)_{4}}=\rho_{P_{U}}\left(A_{P_{U}}+12 A_{O}+4 A_{N}\right) / A_{P_{U}},
\end{gathered}
$$

and

$$
\rho_{\mathrm{HNO}_{3}}=M_{\mathrm{HNO}_{3}}\left(A_{H}+A_{N}+3 A_{O}\right) / 1000 .
$$

In both sets of equations, the parameter definitions are as follows:

$$
\begin{aligned}
\rho_{i} & =\text { density of nuclide }\left(\mathrm{g} / \mathrm{cm}^{3}\right), \\
M_{\mathrm{HNO}_{3}} & =\text { molarity }(\mathrm{mol} / \mathrm{L}), \\
\mathrm{A}_{\mathrm{i}} & =\text { isotopic mass }(\mathrm{g} / \mathrm{mol}), \\
\Delta \mathrm{T} & =\left(\mathrm{T}^{\circ} \mathrm{C}-22.5\right) .
\end{aligned}
$$




\section{CALCULATIONS}

\subsection{URANIUM OXIDE-WATER MIXTURES}

The uranium isotopic compositions involve only ${ }^{235} \mathrm{U}$ and ${ }^{238} \mathrm{U}$. The following uranium oxide enrichments have been considered in this study: $U(3), U(4), U(5), U(20)$, and $U(100) w t \%{ }^{235} U$.

In all calculations the composition of the homogeneous uranium oxide-water mixture was calculated using available options in CSAS1X. The default density value of $10.96 \mathrm{~g} / \mathrm{cm}^{3}$ was used for $\mathrm{UO}_{2}$, and $0.9982 \mathrm{~g} / \mathrm{cm}^{3}$ was used for the density of $\mathrm{H}_{2} \mathrm{O}$. Cross sections were calculated with a temperature of $293 \mathrm{~K}$.

A series of CSAS1X calculations of the critical parameters (dimensions, masses, and concentrations) with varying volume fractions of $\mathrm{UO}_{2}$ and $\mathrm{H}_{2} \mathrm{O}$ were performed for spheres, cylinders, slabs, and infinite media. Plots of these calculations are shown in Figs. A.1-A.20 (Appendix A). For each sphere radius, mass was calculated as density times volume, where density was calculated as $\mathrm{N}_{235} * 235.0441$ / 0.60221368 (ref. 7) and the volume is from the output of the calculation. Total grams of uranium as shown in Table 1 are grams of ${ }^{235} \mathrm{U}$ divided by weight fraction of ${ }^{235} \mathrm{U}$.

Concentration was calculated as $10.96 \mathrm{~g} \mathrm{UO}_{2} / \mathrm{cm}^{3} * \mathrm{VF} *\left(\mathrm{U} / \mathrm{UO}_{2}\right) * 1000$, where $\mathrm{VF}$ is the volume fraction of the CSAS1X case where k-infinity equals 1 . The value of $\mathrm{U} / \mathrm{UO}_{2}$ was calculated as $\left({ }^{235} \mathrm{U}\right.$ wt $\%$ $* 235.0441+{ }^{238} \mathrm{U}$ wt \% * 238.0510) / $\left({ }^{235} \mathrm{U}\right.$ wt \% * 235.0441 + ${ }^{238} \mathrm{U}$ wt \% *238.0510 + $\left.2 * 15.9906\right)$. Atomic weights are from the SCALE Standard Composition Library (Sect. M8) based on ENDF/B-V data.

\subsection{URANIUM NITRATE-WATER SOLUTIONS}

The uranium isotopic compositions involve only ${ }^{235} \mathrm{U}$ and ${ }^{238} \mathrm{U}$. The following uranium nitrate enrichments have been considered in this study: $\mathrm{U}(3), \mathrm{U}(4), \mathrm{U}(5), \mathrm{U}(20)$, and $\mathrm{U}(100) \mathrm{wt} \% \mathrm{U}$.

The composition of the homogeneous uranium nitrate-water material was calculated using the builtin SCALE atomic number density equations for uranyl nitrate $\left(\mathrm{UO}_{2}\left(\mathrm{NO}_{3}\right)_{2}\right)$ solution per ARH-600 (ref. 6). The uranium density of a hydrated uranyl nitrate crystal is about $1296 \mathrm{~g} / \mathrm{L}$, which is about the density of the $3 \%$ minimum volume. Cross sections were calculated with a temperature of $293 \mathrm{~K}$.

A series of CSAS1X calculations of the critical parameters (dimensions, masses, and concentrations) with varying uranium density were performed for spheres, cylinders, slabs, and infinite media. Plots of these calculations are shown in Figs. B.1-B.20 (Appendix B). SCALE warns the user when the uranium density is higher than what a real solution would support. If the input uranium density is higher than the theoretical density for a hydrated uranyl crystal, an error is given by SCALE and the calculations are stopped. The maximum uranium density is about $1296 \mathrm{~g} / \mathrm{L}$ for $3 \%$ enriched uranium. The uranium density is dependent on the enrichment. Values calculated and reported above $1296 \mathrm{~g} / \mathrm{L}$ are higher than those for a pure solution. Values above $1296 \mathrm{~g} / \mathrm{L}$ were calculated using volume fractions in the CSAS1X calculations. The volume fraction for uranyl nitrate $\left(\mathrm{UO}_{2}\left(\mathrm{NO}_{3}\right)_{2}\right)$ was determined as the selected $\mathrm{UO}_{2}\left(\mathrm{NO}_{3}\right)_{2}$ density divided by the theoretical density of $\mathrm{UO}_{2}\left(\mathrm{NO}_{3}\right)_{2}$. The volume fraction for the water was determined as 1.5644 minus the volume fraction of $\mathrm{UO}_{2}\left(\mathrm{NO}_{3}\right)_{2}$, where 1.5644 is the sum of the density multipliers at the point where the solution reaches the fully hydrated salt [i.e., $\mathrm{UO}_{2}\left(\mathrm{NO}_{3}\right)_{2} \cdot 6 \mathrm{H}_{2} \mathrm{O}$ ]. It was assumed that this sum remained constant for some range of uranium density above this point; therefore, adding uranium reduced the amount of hydration.

The minimum critical mass was calculated as volume times density (in grams per liter). Infinite geometry CSAS1X cases with varying uranium density for the uranyl nitrate $\left[\mathrm{UO}_{2}\left(\mathrm{NO}_{3}\right)_{2}\right]$ solution were performed to obtain k-infinity. Concentration (in grams per liter) is the density resulting in k-infinity equal to 1. Minimum values for uranium nitrate-water systems are shown in Table 2. 
Table 1. $\mathrm{UO}_{2}-\mathrm{H}_{2} \mathrm{O}$, water reflected $(30 \mathrm{~cm})$

\begin{tabular}{|c|c|c|c|c|c|c|c|c|}
\hline \multicolumn{9}{|c|}{ Enrichment 3 wt $\%{ }^{235} \mathrm{U}$} \\
\hline \multicolumn{3}{|c|}{ Sphere } & \multicolumn{2}{|c|}{ Cylinder } & \multicolumn{2}{|c|}{ Slab } & \multicolumn{2}{|c|}{ Concentration } \\
\hline & $\begin{array}{l}\text { Min. } \\
\text { mass }\end{array}$ & $\begin{array}{l}\text { Min. } \\
\text { vol. }\end{array}$ & & $\begin{array}{c}\text { Min. } \\
\text { values }\end{array}$ & & $\begin{array}{l}\text { Min. } \\
\text { values }\end{array}$ & $(\mathrm{g} \mathrm{U} / \mathrm{L})$ & $(\mathrm{H} / \mathrm{U})$ \\
\hline $\begin{array}{l}\text { Radius } \\
(\mathrm{cm})\end{array}$ & 26.85 & 23.43 & $\begin{array}{l}\text { Diameter } \\
(\mathrm{cm})\end{array}$ & 32.7 & $\begin{array}{l}\text { Thickness } \\
(\mathrm{cm})\end{array}$ & 16.7 & 521 & 47.9 \\
\hline $\begin{array}{l}\text { Density } \\
\text { (g U/L) }\end{array}$ & 1256 & 2319 & $\begin{array}{l}\text { Density } \\
\text { (g U/L) }\end{array}$ & 2415 & $\begin{array}{l}\text { Density } \\
(\mathrm{g} \text { U/L) }\end{array}$ & 2512 & & \\
\hline $\begin{array}{l}\text { Volume } \\
\text { (L) }\end{array}$ & 81.06 & 53.9 & $\begin{array}{l}\text { Linear density }{ }^{a} \\
(\mathrm{~kg} \mathrm{U} / \mathrm{m})\end{array}$ & 202.816 & $\begin{array}{l}\text { Areal density } \\
\left(\mathrm{kg} \mathrm{U} / \mathrm{m}^{2}\right)\end{array}$ & 419.504 & & \\
\hline $\begin{array}{l}\text { Mass } \\
(\mathrm{kg} \mathrm{U})\end{array}$ & 101.8 & 125.0 & & & & & & \\
\hline \multicolumn{9}{|c|}{ Enrichment 4 wt \% ${ }^{235} \mathrm{U}$} \\
\hline \multicolumn{3}{|c|}{ Sphere } & \multicolumn{2}{|c|}{ Cylinder } & \multicolumn{2}{|l|}{ Slab } & \multicolumn{2}{|c|}{ Concentration } \\
\hline & $\begin{array}{l}\text { Min. } \\
\text { mass }\end{array}$ & $\begin{array}{l}\text { Min. } \\
\text { vol. }\end{array}$ & & $\begin{array}{l}\text { Min. } \\
\text { values }\end{array}$ & & $\begin{array}{l}\text { Min. } \\
\text { values }\end{array}$ & $(\mathrm{g} \mathrm{U} / \mathrm{L})$ & $(\mathrm{H} / \mathrm{U})$ \\
\hline $\begin{array}{l}\text { Radius } \\
(\mathrm{cm})\end{array}$ & 22.43 & 20.47 & $\begin{array}{l}\text { Diameter } \\
(\mathrm{cm})\end{array}$ & 28.2 & $\begin{array}{l}\text { Thickness } \\
\text { (cm) }\end{array}$ & 13.8 & 369.4 & 68.7 \\
\hline $\begin{array}{l}\text { Density } \\
\text { (g U/L) }\end{array}$ & 1159 & 2029 & $\begin{array}{l}\text { Density } \\
(\mathrm{g} \mathrm{U} / \mathrm{L})\end{array}$ & 2125 & $\begin{array}{l}\text { Density } \\
(\mathrm{g} \text { U/L) }\end{array}$ & 2319 & & \\
\hline $\begin{array}{l}\text { Volume } \\
\text { (L) }\end{array}$ & 47.3 & 35.9 & $\begin{array}{l}\text { Linear density } \\
(\mathrm{kg} \mathrm{U} / \mathrm{m})\end{array}$ & 132.723 & $\begin{array}{l}\text { Areal density } \\
\left(\mathrm{kg} \mathrm{U} / \mathrm{m}^{2}\right)\end{array}$ & 320.022 & & \\
\hline $\begin{array}{l}\text { Mass } \\
(\mathrm{kg} \mathrm{U})\end{array}$ & 54.8 & 72.8 & & & & & & \\
\hline \multicolumn{9}{|c|}{ Enrichment 5 wt \% ${ }^{235} \mathrm{U}$} \\
\hline \multicolumn{3}{|c|}{ Sphere } & \multicolumn{2}{|c|}{ Cylinder } & \multicolumn{2}{|l|}{ Slab } & \multicolumn{2}{|c|}{ Concentration } \\
\hline & $\begin{array}{l}\text { Min. } \\
\text { mass }\end{array}$ & $\begin{array}{l}\text { Min. } \\
\text { vol. }\end{array}$ & & $\begin{array}{l}\text { Min. } \\
\text { values }\end{array}$ & & $\begin{array}{l}\text { Min. } \\
\text { values }\end{array}$ & $(\mathrm{g} \mathrm{U} / \mathrm{L})$ & $(\mathrm{H} / \mathrm{U})$ \\
\hline $\begin{array}{l}\text { Radius } \\
(\mathrm{cm})\end{array}$ & 20.86 & 18.81 & $\begin{array}{l}\text { Diameter } \\
(\mathrm{cm})\end{array}$ & 25.7 & $\begin{array}{l}\text { Thickness } \\
(\mathrm{cm})\end{array}$ & 12.2 & 286.6 & 89.5 \\
\hline $\begin{array}{l}\text { Density } \\
\text { (g U/L) }\end{array}$ & 966 & 1932 & $\begin{array}{l}\text { Density } \\
(\mathrm{g} \mathrm{U} / \mathrm{L})\end{array}$ & 1932 & $\begin{array}{l}\text { Density } \\
(\mathrm{g} \text { U/L) }\end{array}$ & 2125 & & \\
\hline $\begin{array}{l}\text { Volume } \\
\text { (L) }\end{array}$ & 38.02 & 27.9 & $\begin{array}{l}\text { Linear density } \\
(\mathrm{kg} \mathrm{U} / \mathrm{m})\end{array}$ & 100.222 & $\begin{array}{l}\text { Areal density } \\
\left(\mathrm{kg} \mathrm{U} / \mathrm{m}^{2}\right)\end{array}$ & 259.250 & & \\
\hline $\begin{array}{l}\text { Mass } \\
(\mathrm{kg} \mathrm{U})\end{array}$ & 36.7 & 53.9 & & & & & & \\
\hline
\end{tabular}


Table 1 (continued)

\begin{tabular}{|c|c|c|c|c|c|c|c|c|}
\hline \multicolumn{9}{|c|}{ Enrichment 20 wt $\%{ }^{235} \mathrm{U}$} \\
\hline \multicolumn{3}{|c|}{ Sphere } & \multicolumn{2}{|c|}{ Cylinder } & \multicolumn{2}{|l|}{ Slab } & \multicolumn{2}{|c|}{ Concentration } \\
\hline & $\begin{array}{l}\text { Min. } \\
\text { mass }\end{array}$ & $\begin{array}{l}\text { Min. } \\
\text { vol. }\end{array}$ & & $\begin{array}{c}\text { Min. } \\
\text { values }\end{array}$ & & $\begin{array}{l}\text { Min. } \\
\text { values }\end{array}$ & $(\mathrm{g} \mathrm{U} / \mathrm{L})$ & $(\mathrm{H} / \mathrm{U})$ \\
\hline $\begin{array}{l}\text { Radius } \\
(\mathrm{cm})\end{array}$ & 16.24 & 13.68 & $\begin{array}{l}\text { Diameter } \\
(\mathrm{cm})\end{array}$ & 17.9 & $\begin{array}{l}\text { Thickness } \\
\text { (cm) }\end{array}$ & 7.2 & 64.7 & 411.5 \\
\hline $\begin{array}{l}\text { Density } \\
\text { (g U/L) }\end{array}$ & 290 & 1062 & $\begin{array}{l}\text { Density } \\
\text { (g U/L) }\end{array}$ & 1159 & $\begin{array}{l}\text { Density } \\
(\mathrm{g} \mathrm{U} / \mathrm{L})\end{array}$ & 1449 & & \\
\hline $\begin{array}{l}\text { Volume } \\
\text { (L) }\end{array}$ & 17.9 & 10.7 & $\begin{array}{l}\text { Linear density } \\
(\mathrm{kg} \mathrm{U} / \mathrm{m})\end{array}$ & 29.166 & $\begin{array}{l}\text { Areal density } \\
\left(\mathrm{kg} \mathrm{U} / \mathrm{m}^{2}\right)\end{array}$ & 104.328 & & \\
\hline $\begin{array}{l}\text { Mass } \\
(\mathrm{kg} \mathrm{U})\end{array}$ & 5.2 & 11.4 & & & & & & \\
\hline \multicolumn{9}{|c|}{ Enrichment 100 wt $\%{ }^{235} U$} \\
\hline \multicolumn{3}{|c|}{ Sphere } & \multicolumn{2}{|c|}{ Cylinder } & \multicolumn{2}{|l|}{ Slab } & \multicolumn{2}{|c|}{ Concentration } \\
\hline & $\begin{array}{l}\text { Min. } \\
\text { mass }\end{array}$ & $\begin{array}{l}\text { Min. } \\
\text { vol. }\end{array}$ & & $\begin{array}{c}\text { Min. } \\
\text { values }\end{array}$ & & $\begin{array}{l}\text { Min. } \\
\text { values }\end{array}$ & $(\mathrm{g} \mathrm{U} / \mathrm{L})$ & $(\mathrm{H} / \mathrm{U})$ \\
\hline $\begin{array}{l}\text { Radius } \\
(\mathrm{cm})\end{array}$ & 14.82 & 10.08 & $\begin{array}{l}\text { Diameter } \\
(\mathrm{cm})\end{array}$ & 12.4 & $\begin{array}{l}\text { Thickness } \\
(\mathrm{cm})\end{array}$ & 3.4 & 12.17 & 2141.2 \\
\hline $\begin{array}{l}\text { Density } \\
\text { (g U/L) }\end{array}$ & 58 & 9647 & $\begin{array}{l}\text { Density } \\
(\mathrm{g} \mathrm{U} / \mathrm{L})\end{array}$ & 10574 & $\begin{array}{l}\text { Density } \\
\text { (g U/L) }\end{array}$ & 9647 & & \\
\hline $\begin{array}{l}\text { Volume } \\
\text { (L) }\end{array}$ & 13.6 & 4.3 & $\begin{array}{l}\text { Linear density }{ }^{a} \\
(\mathrm{~kg} \mathrm{U} / \mathrm{m})\end{array}$ & 127.694 & $\begin{array}{l}\text { Areal density } \\
\left(\mathrm{kg} \mathrm{U} / \mathrm{m}^{2}\right)\end{array}$ & 327.998 & & \\
\hline $\begin{array}{l}\text { Mass } \\
(\mathrm{kg} \mathrm{U})\end{array}$ & 0.79 & 41.5 & & & & & & \\
\hline
\end{tabular}

${ }^{a}$ Linear density (cylinders): density $(\mathrm{g} \mathrm{U} / \mathrm{L}) *(\pi / 4)\left(\mathrm{d}^{2}\right) * 10^{-4}=\mathrm{kg} \mathrm{U} / \mathrm{m}, \mathrm{d}=$ diameter.

${ }^{b}$ Areal density (slab): density $(\mathrm{g} \mathrm{U} / \mathrm{L}) * \mathrm{t} * 10^{-2}=\mathrm{kg} \mathrm{U} / \mathrm{m}^{2}, \mathrm{t}=$ thickness. 
Table 2. UNH- $\mathrm{H}_{2} \mathrm{O}$, water reflected $(30 \mathrm{~cm})$

\begin{tabular}{|c|c|c|c|c|c|c|c|c|}
\hline \multicolumn{9}{|c|}{ Enrichment 3 wt $\%{ }^{235} \mathrm{U}$} \\
\hline \multicolumn{3}{|c|}{ Sphere } & \multicolumn{2}{|c|}{ Cylinder } & \multicolumn{2}{|l|}{ Slab } & \multicolumn{2}{|c|}{ Concentration } \\
\hline & $\begin{array}{l}\text { Min. } \\
\text { mass }\end{array}$ & $\begin{array}{l}\text { Min. } \\
\text { vol. }\end{array}$ & & $\begin{array}{c}\text { Min. } \\
\text { values }\end{array}$ & & $\begin{array}{c}\text { Min. } \\
\text { values }\end{array}$ & $(\mathrm{g} \mathrm{U} / \mathrm{L})$ & $(\mathrm{H} / \mathrm{U})$ \\
\hline $\begin{array}{l}\text { Radius } \\
(\mathrm{cm})\end{array}$ & 46.86 & 45.9 & $\begin{array}{l}\text { Diameter } \\
(\mathrm{cm})\end{array}$ & 66.96 & $\begin{array}{l}\text { Thickness } \\
(\mathrm{cm})\end{array}$ & 38.72 & 624.6 & 34.0 \\
\hline $\begin{array}{l}\text { Density } \\
\text { (g U/L) }\end{array}$ & 1140 & 1295 & $\begin{array}{l}\text { Density } \\
(\mathrm{g} U / \mathrm{L})\end{array}$ & 1297 & $\begin{array}{l}\text { Density } \\
(\mathrm{g} \text { U/L) }\end{array}$ & 1300 & & \\
\hline $\begin{array}{l}\text { Volume } \\
\text { (L) }\end{array}$ & 431.1 & 405 & $\begin{array}{l}\text { Linear density } \\
(\mathrm{kg} \mathrm{U} / \mathrm{m})\end{array}$ & 456.731 & $\begin{array}{l}\text { Areal density } \\
\left(\mathrm{kg} \mathrm{U} / \mathrm{m}^{2}\right)\end{array}$ & 503.360 & & \\
\hline $\begin{array}{l}\text { Mass } \\
(\mathrm{kg} \mathrm{U})\end{array}$ & 491 & 524 & & & & & & \\
\hline \multicolumn{9}{|c|}{ Enrichment 4 wt \% ${ }^{235} \mathrm{U}$} \\
\hline \multicolumn{3}{|c|}{ Sphere } & \multicolumn{2}{|c|}{ Cylinder } & \multicolumn{2}{|l|}{ Slab } & \multicolumn{2}{|c|}{ Concentration } \\
\hline & $\begin{array}{l}\text { Min. } \\
\text { mass }\end{array}$ & $\begin{array}{l}\text { Min. } \\
\text { vol. }\end{array}$ & & $\begin{array}{c}\text { Min. } \\
\text { values }\end{array}$ & & $\begin{array}{c}\text { Min. } \\
\text { values }\end{array}$ & (g U/L) & $(\mathrm{H} / \mathrm{U})$ \\
\hline $\begin{array}{l}\text { Radius } \\
(\mathrm{cm})\end{array}$ & 33.95 & 32.69 & $\begin{array}{l}\text { Diameter } \\
(\mathrm{cm})\end{array}$ & 46.89 & $\begin{array}{l}\text { Thickness } \\
(\mathrm{cm})\end{array}$ & 25.77 & 415.5 & 55.3 \\
\hline $\begin{array}{l}\text { Density } \\
(\mathrm{g} \mathrm{U} / \mathrm{L})\end{array}$ & 910 & 1145 & $\begin{array}{l}\text { Density } \\
(\mathrm{g} \mathrm{U} / \mathrm{L})\end{array}$ & 1155 & $\begin{array}{l}\text { Density } \\
\text { (g U/L) }\end{array}$ & 1180 & & \\
\hline $\begin{array}{l}\text { Volume } \\
\text { (L) }\end{array}$ & 163.95 & 146.3 & $\begin{array}{l}\text { Linear density } \\
(\mathrm{kg} \mathrm{U} / \mathrm{m})\end{array}$ & 199.449 & $\begin{array}{l}\text { Areal density } \\
\left(\mathrm{kg} \mathrm{U} / \mathrm{m}^{2}\right)\end{array}$ & 304.086 & & \\
\hline $\begin{array}{l}\text { Mass } \\
(\mathrm{kg} \mathrm{U})\end{array}$ & 149.1 & 167.5 & & & & & & \\
\hline \multicolumn{9}{|c|}{ Enrichment 5 wt \% ${ }^{235} \mathrm{U}$} \\
\hline \multicolumn{3}{|c|}{ Sphere } & \multicolumn{2}{|c|}{ Cylinder } & \multicolumn{2}{|l|}{ Slab } & \multicolumn{2}{|c|}{ Concentration } \\
\hline & $\begin{array}{l}\text { Min. } \\
\text { mass }\end{array}$ & $\begin{array}{l}\text { Min. } \\
\text { vol. }\end{array}$ & & $\begin{array}{l}\text { Min. } \\
\text { values }\end{array}$ & & $\begin{array}{c}\text { Min. } \\
\text { values }\end{array}$ & (g U/L) & $(\mathrm{H} / \mathrm{U})$ \\
\hline $\begin{array}{l}\text { Radius } \\
(\mathrm{cm})\end{array}$ & 28.84 & 27.39 & $\begin{array}{l}\text { Diameter } \\
\text { (cm) }\end{array}$ & 38.79 & $\begin{array}{l}\text { Thickness } \\
\text { (cm) }\end{array}$ & 20.57 & 311.5 & 76.6 \\
\hline $\begin{array}{l}\text { Density } \\
\text { (g U/L) }\end{array}$ & 765 & 1050 & $\begin{array}{l}\text { Density } \\
(\mathrm{g} \mathrm{U} / \mathrm{L})\end{array}$ & 1055 & $\begin{array}{l}\text { Density } \\
(\mathrm{g} \mathrm{U} / \mathrm{L})\end{array}$ & 1090 & & \\
\hline $\begin{array}{l}\text { Volume } \\
\text { (L) }\end{array}$ & 100.433 & 86.1 & $\begin{array}{l}\text { Linear density }{ }^{a} \\
(\mathrm{~kg} \mathrm{U} / \mathrm{m})\end{array}$ & 124.676 & $\begin{array}{l}\text { Areal density } \\
\left(\mathrm{kg} \mathrm{U} / \mathrm{m}^{2}\right)\end{array}$ & 224.213 & & \\
\hline $\begin{array}{l}\text { Mass } \\
(\mathrm{kg} \mathrm{U})\end{array}$ & 76.8 & 90.4 & & & & & & \\
\hline
\end{tabular}


Table 2 (continued)

\begin{tabular}{|c|c|c|c|c|c|c|c|c|}
\hline \multicolumn{9}{|c|}{ Enrichment 20 wt $\%{ }^{235} \mathrm{U}$} \\
\hline \multicolumn{3}{|c|}{ Sphere } & \multicolumn{2}{|c|}{ Cylinder } & \multicolumn{2}{|l|}{ Slab } & \multicolumn{2}{|c|}{ Concentration } \\
\hline & $\begin{array}{l}\text { Min. } \\
\text { mass }\end{array}$ & $\begin{array}{l}\text { Min. } \\
\text { vol. }\end{array}$ & & $\begin{array}{c}\text { Min. } \\
\text { values }\end{array}$ & & $\begin{array}{c}\text { Min. } \\
\text { values }\end{array}$ & $(\mathrm{g} \mathrm{U} / \mathrm{L})$ & $(\mathrm{H} / \mathrm{U})$ \\
\hline $\begin{array}{l}\text { Radius } \\
(\mathrm{cm})\end{array}$ & 18.57 & 15.72 & $\begin{array}{l}\text { Diameter } \\
(\mathrm{cm})\end{array}$ & 21.04 & $\begin{array}{l}\text { Thickness } \\
(\mathrm{cm})\end{array}$ & 9.24 & 65.0 & 398.2 \\
\hline $\begin{array}{l}\text { Density } \\
(\mathrm{g} \mathrm{U} / \mathrm{L})\end{array}$ & 225 & 600 & $\begin{array}{l}\text { Density } \\
(\mathrm{g} \mathrm{U} / \mathrm{L})\end{array}$ & 620 & $\begin{array}{l}\text { Density } \\
(\mathrm{g} \mathrm{U} / \mathrm{L})\end{array}$ & 710 & & \\
\hline $\begin{array}{l}\text { Volume } \\
\text { (L) }\end{array}$ & 26.816 & 16.3 & $\begin{array}{l}\text { Linear density }^{a} \\
(\mathrm{~kg} \mathrm{U} / \mathrm{m})\end{array}$ & 21.556 & $\begin{array}{l}\text { Areal density } \\
\left(\mathrm{kg} \mathrm{U} / \mathrm{m}^{2}\right)\end{array}$ & 65.604 & & \\
\hline $\begin{array}{l}\text { Mass } \\
(\mathrm{kg} \mathrm{U})\end{array}$ & 6.0 & 9.8 & & & & & & \\
\hline \multicolumn{9}{|c|}{ Enrichment 100 wt $\%{ }^{235} \mathrm{U}$} \\
\hline \multicolumn{3}{|c|}{ Sphere } & \multicolumn{2}{|c|}{ Cylinder } & \multirow[t]{2}{*}{ Slab } & & \multicolumn{2}{|c|}{ Concentration } \\
\hline & $\begin{array}{l}\text { Min. } \\
\text { mass }\end{array}$ & $\begin{array}{l}\text { Min. } \\
\text { vol. }\end{array}$ & & $\begin{array}{c}\text { Min. } \\
\text { values }\end{array}$ & & $\begin{array}{c}\text { Min. } \\
\text { values }\end{array}$ & $(\mathrm{g} \mathrm{U} / \mathrm{L})$ & $(\mathrm{H} / \mathrm{U})$ \\
\hline $\begin{array}{l}\text { Radius } \\
(\mathrm{cm})\end{array}$ & 15.20 & 11.74 & $\begin{array}{l}\text { Diameter } \\
(\mathrm{cm})\end{array}$ & 15.04 & $\begin{array}{l}\text { Thickness } \\
(\mathrm{cm})\end{array}$ & 5.44 & 12.25 & $2,127.2$ \\
\hline $\begin{array}{l}\text { Density } \\
(\mathrm{g} \mathrm{U} / \mathrm{L})\end{array}$ & 55 & 350 & $\begin{array}{l}\text { Density } \\
(\mathrm{g} \mathrm{U} / \mathrm{L})\end{array}$ & 375 & $\begin{array}{l}\text { Density } \\
(\mathrm{g} \mathrm{U} / \mathrm{L})\end{array}$ & 500 & & \\
\hline $\begin{array}{l}\text { Volume } \\
\text { (L) }\end{array}$ & 14.698 & 6.8 & $\begin{array}{l}\text { Linear density }^{a} \\
(\mathrm{~kg} \mathrm{U} / \mathrm{m})\end{array}$ & 6.662 & $\begin{array}{l}\text { Areal density } \\
\left(\mathrm{kg} \mathrm{U} / \mathrm{m}^{2}\right)\end{array}$ & 27.200 & & \\
\hline $\begin{array}{l}\text { Mass } \\
(\mathrm{kg} \mathrm{U})\end{array}$ & 0.808 & 2.4 & & & & & & \\
\hline
\end{tabular}

${ }^{a}$ Linear density (cylinders): density $(\mathrm{g} \mathrm{U} / \mathrm{L}) *(\pi / 4)\left(\mathrm{d}^{2}\right) * 10^{-4}=\mathrm{kg} \mathrm{U} / \mathrm{m}, \mathrm{d}=$ diameter.

${ }^{b}$ Areal density (slab): density (g U/L)* $\mathrm{t} * 10^{-2}=\mathrm{kg} \mathrm{U} / \mathrm{m}^{2}, \mathrm{t}=$ thickness. 


\subsection{PLUTONIUM OXIDE-WATER MIXTURES}

The plutonium isotopic compositions include ${ }^{239} \mathrm{Pu},{ }^{240} \mathrm{Pu},{ }^{241} \mathrm{Pu}$, and ${ }^{242} \mathrm{Pu}$. The following plutonium isotopic weight percent compositions have been considered in this study: $\mathrm{Pu}(100 / 0 / 0 / 0), \mathrm{Pu}(95 / 5 / 0 / 0)$, $\mathrm{Pu}(90 / 5 / 5 / 0)$, and $\mathrm{Pu}(80 / 10 / 10 / 0)$, plus the more realistic vector $\mathrm{Pu}(71 / 17 / 11 / 1)$.

In all calculations the composition of the homogeneous plutonium oxide-water mixture was calculated using available options in CSAS1X. The default density value of $11.86 \mathrm{~g} / \mathrm{cm}^{3}$ was used for $\mathrm{PuO}_{2}$, and $0.9982 \mathrm{~g} / \mathrm{cm}^{3}$ was used for the density of $\mathrm{H}_{2} \mathrm{O}$. Cross sections were calculated with a temperature of $293 \mathrm{~K}$.

A series of CSAS1X calculations of the critical parameters (dimensions, masses, and concentrations) with varying volume fractions of $\mathrm{PuO}_{2}$ and $\mathrm{H}_{2} \mathrm{O}$ were performed for spheres, cylinders, slabs, and infinite media. Plots of these calculations are shown in Figs. C.1-C.20 (Appendix C), where "enrichment" refers to the ${ }^{239} \mathrm{Pu}$ weight percent of the plutonium. The minimum critical mass is calculated as density times volume, where density is calculated as $\left[\left(\mathrm{N}_{239} * 239.0526\right)+\left(\mathrm{N}_{240} * 240.0542\right)+\left(\mathrm{N}_{241} * 241.0487\right)+\left(\mathrm{N}_{242}\right.\right.$ $* 242.0584)$ ] / 0.60221368. Atomic weights are from the SCALE Standard Composition Library based on ENDF/B-V data.

Infinite geometry CSAS1X cases with varying volume fractions for the $\mathrm{PuO}_{2}$ and $\mathrm{H}_{2} \mathrm{O}$ were run to obtain k-infinity. Concentrations can be calculated from this data. The minimum critical concentration was calculated as $\mathrm{Pu} / \mathrm{PuO}_{2} * \mathrm{VF}$, where VF is the $\mathrm{PuO}_{2}$ volume fraction of the CSAS1X case where kinfinity equals 1 . The value of $\mathrm{Pu} / \mathrm{PuO}_{2}$ is calculated as $\left[\left(\mathrm{N}_{239} * 239.0526\right)+\left(\mathrm{N}_{240} * 240.0542\right)+\left(\mathrm{N}_{241}\right.\right.$ * $\left.241.0487)+\left(\mathrm{N}_{242} * 242.0584\right)\right] /\left[\left(\mathrm{N}_{239} * 239.0526\right)+\left(\mathrm{N}_{240} * 240.0542\right)+\left(\mathrm{N}_{241} * 241.0487\right)+\left(\mathrm{N}_{242} *\right.\right.$ $242.0584)+31.9812]$. Minimum values for plutonium oxide-water systems are shown in Table 3. 
Table 3. $\mathrm{PuO}_{2}-\mathrm{H}_{2} \mathrm{O}$, water reflected $(30 \mathrm{~cm})$

\begin{tabular}{|c|c|c|c|c|c|c|c|c|}
\hline \multicolumn{9}{|c|}{$\mathrm{Pu}(100,0,0,0) \mathrm{O}_{2}$} \\
\hline \multicolumn{3}{|c|}{ Sphere } & \multicolumn{2}{|c|}{ Cylinder } & \multicolumn{2}{|l|}{ Slab } & \multicolumn{2}{|c|}{ Concentration } \\
\hline & $\begin{array}{l}\text { Min. } \\
\text { mass }\end{array}$ & $\begin{array}{l}\text { Min. } \\
\text { vol. }\end{array}$ & & $\begin{array}{l}\text { Min. } \\
\text { values }\end{array}$ & & $\begin{array}{c}\text { Min. } \\
\text { values }\end{array}$ & $(\mathrm{g} \mathrm{Pu} / \mathrm{L})$ & $(\mathrm{H} / \mathrm{Pu})$ \\
\hline $\begin{array}{l}\text { Radius } \\
(\mathrm{cm})\end{array}$ & 15.76 & 6.49 & $\begin{array}{l}\text { Diameter } \\
(\mathrm{cm})\end{array}$ & 7.667 & $\begin{array}{l}\text { Thickness } \\
\text { (cm) }\end{array}$ & 1.723 & 7.091 & 3691 \\
\hline $\begin{array}{l}\text { Density } \\
(\mathrm{g} \mathrm{Pu} / \mathrm{L})\end{array}$ & 30.32 & 10107 & $\begin{array}{l}\text { Density } \\
(\mathrm{g} \mathrm{Pu} / \mathrm{L})\end{array}$ & 10107 & $\begin{array}{l}\text { Density } \\
(\mathrm{g} \mathrm{Pu} / \mathrm{L})\end{array}$ & 10107 & & \\
\hline $\begin{array}{l}\text { Volume } \\
\text { (L) }\end{array}$ & 16.389 & 1.144 & $\begin{array}{l}\text { Linear density }{ }^{a} \\
(\mathrm{~kg} \mathrm{Pu} / \mathrm{m})\end{array}$ & 46.661 & $\begin{array}{l}\text { Areal density } \\
\left(\mathrm{kg} \mathrm{Pu} / \mathrm{m}^{2}\right)\end{array}$ & 174.143 & & \\
\hline $\begin{array}{l}\text { Mass } \\
(\mathrm{kg} \mathrm{Pu})\end{array}$ & 0.497 & 11562 & & & & & & \\
\hline \multicolumn{9}{|c|}{$\mathrm{Pu}(95,5,5,0) \mathrm{O}_{2}$} \\
\hline \multicolumn{3}{|c|}{ Sphere } & \multicolumn{2}{|c|}{ Cylinder } & \multicolumn{2}{|l|}{ Slab } & \multicolumn{2}{|c|}{ Concentration } \\
\hline & $\begin{array}{l}\text { Min. } \\
\text { mass }\end{array}$ & $\begin{array}{l}\text { Min. } \\
\text { vol. }\end{array}$ & & $\begin{array}{c}\text { Min. } \\
\text { values }\end{array}$ & & $\begin{array}{c}\text { Min. } \\
\text { values }\end{array}$ & $(\mathrm{g} \mathrm{Pu} / \mathrm{L})$ & $(\mathrm{H} / \mathrm{Pu})$ \\
\hline $\begin{array}{l}\text { Radius } \\
(\mathrm{cm})\end{array}$ & 16.80 & 6.64 & $\begin{array}{l}\text { Diameter } \\
(\mathrm{cm})\end{array}$ & 7.926 & $\begin{array}{l}\text { Thickness } \\
\text { (cm) }\end{array}$ & 1.927 & 7.640 & 3426 \\
\hline $\begin{array}{l}\text { Density } \\
(\mathrm{g} \mathrm{Pu} / \mathrm{L})\end{array}$ & 30.32 & 10108 & $\begin{array}{l}\text { Density } \\
(\mathrm{g} \mathrm{Pu} / \mathrm{L})\end{array}$ & 10108 & $\begin{array}{l}\text { Density } \\
(\mathrm{g} \mathrm{Pu} / \mathrm{L})\end{array}$ & 10108 & & \\
\hline $\begin{array}{l}\text { Volume } \\
\text { (L) }\end{array}$ & 19.854 & 1.227 & $\begin{array}{l}\text { Linear density } \\
(\mathrm{kg} \mathrm{Pu} / \mathrm{m})\end{array}$ & 49.872 & $\begin{array}{l}\text { Areal density } \\
\left(\mathrm{kg} \mathrm{Pu} / \mathrm{m}^{2}\right)\end{array}$ & 194.781 & & \\
\hline $\begin{array}{l}\text { Mass } \\
(\mathrm{kg} \mathrm{Pu})\end{array}$ & 0.602 & 12404 & & & & & & \\
\hline \multicolumn{9}{|c|}{$\mathrm{Pu}(90,5,5,0) \mathrm{O}_{2}$} \\
\hline \multicolumn{3}{|c|}{ Sphere } & \multicolumn{2}{|c|}{ Cylinder } & \multicolumn{2}{|l|}{ Slab } & \multicolumn{2}{|c|}{ Concentration } \\
\hline & $\begin{array}{l}\text { Min. } \\
\text { mass }\end{array}$ & $\begin{array}{l}\text { Min. } \\
\text { vol. }\end{array}$ & & $\begin{array}{l}\text { Min. } \\
\text { values }\end{array}$ & & $\begin{array}{c}\text { Min. } \\
\text { values }\end{array}$ & $(\mathrm{g} \mathrm{Pu} / \mathrm{L})$ & $(\mathrm{H} / \mathrm{Pu})$ \\
\hline $\begin{array}{l}\text { Radius } \\
(\mathrm{cm})\end{array}$ & 16.56 & 6.62 & $\begin{array}{l}\text { Diameter } \\
(\mathrm{cm})\end{array}$ & 7.871 & $\begin{array}{l}\text { Thickness } \\
\text { (cm) }\end{array}$ & 1.845 & 7.470 & 3505 \\
\hline $\begin{array}{l}\text { Density } \\
(\mathrm{g} \mathrm{Pu} / \mathrm{L})\end{array}$ & 30.31 & 10108 & $\begin{array}{l}\text { Density } \\
(\mathrm{g} \mathrm{Pu} / \mathrm{L})\end{array}$ & 10108 & $\begin{array}{l}\text { Density } \\
(\mathrm{g} \mathrm{Pu} / \mathrm{L})\end{array}$ & 10108 & & \\
\hline $\begin{array}{l}\text { Volume } \\
\text { (L) }\end{array}$ & 19.039 & 1.217 & $\begin{array}{l}\text { Linear density }{ }^{a} \\
(\mathrm{~kg} \mathrm{Pu} / \mathrm{m})\end{array}$ & 49.183 & $\begin{array}{l}\text { Areal density } \\
\left(\mathrm{kg} \mathrm{Pu} / \mathrm{m}^{2}\right)\end{array}$ & 186.492 & & \\
\hline $\begin{array}{l}\text { Mass } \\
(\mathrm{kg} \mathrm{Pu})\end{array}$ & 0.577 & 12301 & & & & & & \\
\hline
\end{tabular}


Table 3 (continued)

$\mathrm{Pu}\left(\mathbf{8 0 , 1 0 , 1 0 , 0 ) \mathrm { O } _ { 2 }}\right.$

\begin{tabular}{|c|c|c|c|c|c|c|c|c|}
\hline \multicolumn{3}{|c|}{ Sphere } & \multicolumn{2}{|c|}{ Cylinder } & \multicolumn{2}{|l|}{ Slab } & \multicolumn{2}{|c|}{ Concentration } \\
\hline & $\begin{array}{l}\text { Min. } \\
\text { mass }\end{array}$ & $\begin{array}{l}\text { Min. } \\
\text { vol. }\end{array}$ & & $\begin{array}{l}\text { Min. } \\
\text { values }\end{array}$ & & $\begin{array}{l}\text { Min. } \\
\text { values }\end{array}$ & $(\mathrm{g} \mathrm{Pu} / \mathrm{L})$ & $(\mathrm{H} / \mathrm{Pu})$ \\
\hline $\begin{array}{l}\text { Radius } \\
(\mathrm{cm})\end{array}$ & 17.37 & 6.73 & $\begin{array}{l}\text { Diameter } \\
(\mathrm{cm})\end{array}$ & 8.022 & $\begin{array}{l}\text { Thickness } \\
(\mathrm{cm})\end{array}$ & 1.908 & 7.889 & 3320 \\
\hline $\begin{array}{l}\text { Density } \\
(\mathrm{g} \mathrm{Pu} / \mathrm{L})\end{array}$ & 24.24 & 10109 & $\begin{array}{l}\text { Density } \\
(\mathrm{g} \mathrm{Pu} / \mathrm{L})\end{array}$ & 10109 & $\begin{array}{l}\text { Density } \\
(\mathrm{g} \mathrm{Pu} / \mathrm{L})\end{array}$ & 10109 & & \\
\hline $\begin{array}{l}\text { Volume } \\
\text { (L) }\end{array}$ & 21.945 & 1.279 & $\begin{array}{l}\text { Linear density }{ }^{a} \\
(\mathrm{~kg} \mathrm{Pu} / \mathrm{m})\end{array}$ & 51.093 & $\begin{array}{l}\text { Areal density } \\
\left(\mathrm{kg} \mathrm{Pu} / \mathrm{m}^{2}\right)\end{array}$ & 129.879 & & \\
\hline $\begin{array}{l}\text { Mass } \\
(\mathrm{kg} \mathrm{Pu})\end{array}$ & 0.665 & 12929 & & & & & & \\
\hline \multicolumn{9}{|c|}{$\mathrm{Pu}(71,17,11,1) \mathrm{O}_{2}$} \\
\hline \multicolumn{3}{|c|}{ Sphere } & \multicolumn{2}{|c|}{ Cylinder } & \multicolumn{2}{|l|}{ Slab } & \multicolumn{2}{|c|}{ Concentration } \\
\hline & $\begin{array}{l}\text { Min. } \\
\text { mass }\end{array}$ & $\begin{array}{l}\text { Min. } \\
\text { vol. }\end{array}$ & & $\begin{array}{l}\text { Min. } \\
\text { values }\end{array}$ & & $\begin{array}{c}\text { Min. } \\
\text { values }\end{array}$ & $(\mathrm{g} \mathrm{Pu} / \mathrm{L})$ & $(\mathrm{H} / \mathrm{Pu})$ \\
\hline $\begin{array}{l}\text { Radius } \\
(\mathrm{cm})\end{array}$ & 18.08 & 6.94 & $\begin{array}{l}\text { Diameter } \\
(\mathrm{cm})\end{array}$ & 8.335 & $\begin{array}{l}\text { Thickness } \\
(\mathrm{cm})\end{array}$ & 2.096 & 8.968 & 2922 \\
\hline $\begin{array}{l}\text { Density } \\
(\mathrm{g} \mathrm{Pu} / \mathrm{L})\end{array}$ & 35.40 & 10109 & $\begin{array}{l}\text { Density } \\
(\mathrm{g} \mathrm{Pu} / \mathrm{L})\end{array}$ & 10109 & $\begin{array}{l}\text { Density } \\
(\mathrm{g} \mathrm{Pu} / \mathrm{L})\end{array}$ & 10109 & & \\
\hline $\begin{array}{l}\text { Volume } \\
\text { (L) }\end{array}$ & 24.743 & 1.400 & $\begin{array}{l}\text { Linear density } \\
(\mathrm{kg} \mathrm{Pu} / \mathrm{m})\end{array}$ & 55.158 & $\begin{array}{l}\text { Areal density } \\
\left(\mathrm{kg} \mathrm{Pu} / \mathrm{m}^{2}\right)\end{array}$ & 211.884 & & \\
\hline $\begin{array}{l}\text { Mass } \\
(\mathrm{kg} \mathrm{Pu})\end{array}$ & 0.876 & 14152 & & & & & & \\
\hline
\end{tabular}

${ }^{a}$ Linear density (cylinders): $\operatorname{density}(\mathrm{g} \mathrm{Pu} / \mathrm{L}) *(\pi / 4)\left(\mathrm{d}^{2}\right) * 10^{-4}=\mathrm{kg} \mathrm{Pu} / \mathrm{m}, \mathrm{d}=$ diameter.

${ }^{b}$ Areal density (slab): density $(\mathrm{g} \mathrm{Pu} / \mathrm{L}) * \mathrm{t} * 10^{-2}=\mathrm{kg} \mathrm{Pu} / \mathrm{m}^{2}, \mathrm{t}=$ thickness. 


\subsection{PLUTONIUM NITRATE-WATER SOLUTIONS}

The plutonium isotopic compositions involve ${ }^{239} \mathrm{Pu} /{ }^{240} \mathrm{Pu} /{ }^{241} \mathrm{Pu} /{ }^{242} \mathrm{Pu}$. The following plutonium isotopic weight percents have been considered in this study: $\mathrm{Pu}(100 / 0 / 0 / 0), \mathrm{Pu}(95 / 5 / 0 / 0), \mathrm{Pu}(90 / 5 / 5 / 0)$, and $\mathrm{Pu}(80 / 10 / 10 / 0)$, plus the more realistic vector $\mathrm{Pu}(71 / 17 / 11 / 1)$.

The composition of the homogeneous plutonium nitrate-water material was calculated using the built-in SCALE atomic number density equations for plutonium nitrate $\left[\left(\mathrm{Pu}\left(\mathrm{NO}_{3}\right)_{4}\right]\right.$ solution per ARH600 (ref. 6). Cross sections were calculated with a temperature of $293 \mathrm{~K}$.

A series of CSAS1X calculations of the critical parameters (dimensions, masses, and concentrations) with varying solution fuel density were performed for spheres, cylinders, slabs, and infinite media. Plots of these calculations are shown in Figs. D.1-D.20 (Appendix D), where "enrichment" refers to the ${ }^{239} \mathrm{Pu}$ weight percent of the plutonium. The minimum critical mass values for spheres were calculated as volume times density. Infinite CSAS1X cases with varying plutonium density for the plutonium nitrate $\left[\left(\mathrm{Pu}\left(\mathrm{NO}_{3}\right)_{4}\right]\right.$ solution were performed to obtain k-infinity. Concentration (in grams per liter) is the density resulting in k-infinity equal to 1 . Minimum values for plutonium nitrate-water systems are shown in Table 4. 
Table 4. $\mathrm{PuNH}-\mathrm{H}_{2} \mathrm{O}$, water reflected $(30 \mathrm{~cm})$

\begin{tabular}{|c|c|c|c|c|c|c|c|c|}
\hline \multicolumn{9}{|c|}{$\mathrm{Pu}(100,0,0,0)\left(\mathrm{NO}_{3}\right)_{4}$} \\
\hline \multicolumn{3}{|c|}{ Sphere } & \multicolumn{2}{|c|}{ Cylinder } & \multicolumn{2}{|l|}{ Slab } & \multicolumn{2}{|c|}{ Concentration } \\
\hline & $\begin{array}{l}\text { Min. } \\
\text { mass }\end{array}$ & $\begin{array}{l}\text { Min. } \\
\text { vol. }\end{array}$ & & $\begin{array}{l}\text { Min. } \\
\text { values }\end{array}$ & & $\begin{array}{c}\text { Min. } \\
\text { values }\end{array}$ & $(\mathrm{g} \mathrm{Pu} / \mathrm{L})$ & $(\mathrm{H} / \mathrm{Pu})$ \\
\hline $\begin{array}{l}\text { Radius } \\
(\mathrm{cm})\end{array}$ & 15.95 & 12.18 & $\begin{array}{l}\text { Diameter } \\
(\mathrm{cm})\end{array}$ & 15.63 & $\begin{array}{l}\text { Thickness } \\
\text { (cm) }\end{array}$ & 5.68 & 7.21 & 3666 \\
\hline $\begin{array}{l}\text { Density } \\
(\mathrm{g} \mathrm{Pu} / \mathrm{L})\end{array}$ & 30 & 290 & $\begin{array}{l}\text { Density } \\
(\mathrm{g} \mathrm{Pu} / \mathrm{L})\end{array}$ & 340 & $\begin{array}{l}\text { Density } \\
(\mathrm{g} \mathrm{Pu} / \mathrm{L})\end{array}$ & 525 & & \\
\hline $\begin{array}{l}\text { Volume } \\
\text { (L) }\end{array}$ & 16.992 & 7.564 & $\begin{array}{l}\text { Linear density }{ }^{a} \\
(\mathrm{~kg} \mathrm{Pu} / \mathrm{m})\end{array}$ & 6.524 & $\begin{array}{l}\text { Areal density } \\
\left(\mathrm{kg} \mathrm{Pu} / \mathrm{m}^{2}\right)\end{array}$ & 29.820 & & \\
\hline $\begin{array}{l}\text { Mass } \\
(\mathrm{kg} \mathrm{Pu})\end{array}$ & 0.509 & 2.193 & & & & & & \\
\hline \multicolumn{9}{|c|}{$\mathrm{Pu}(95,5,0,0)\left(\mathrm{NO}_{3}\right)_{4}$} \\
\hline \multicolumn{3}{|c|}{ Sphere } & \multicolumn{2}{|c|}{ Cylinder } & \multicolumn{2}{|l|}{ Slab } & \multicolumn{2}{|c|}{ Concentration } \\
\hline & $\begin{array}{l}\text { Min. } \\
\text { mass }\end{array}$ & $\begin{array}{l}\text { Min. } \\
\text { vol. }\end{array}$ & & $\begin{array}{l}\text { Min. } \\
\text { values }\end{array}$ & & $\begin{array}{c}\text { Min. } \\
\text { values }\end{array}$ & $(\mathrm{g} \mathrm{Pu} / \mathrm{L})$ & $(\mathrm{H} / \mathrm{Pu})$ \\
\hline $\begin{array}{l}\text { Radius } \\
(\mathrm{cm})\end{array}$ & 17.01 & 13.66 & $\begin{array}{l}\text { Diameter } \\
(\mathrm{cm})\end{array}$ & 17.88 & $\begin{array}{l}\text { Thickness } \\
(\mathrm{cm})\end{array}$ & 7.15 & 7.77 & 3403 \\
\hline $\begin{array}{l}\text { Density } \\
(\mathrm{g} \mathrm{Pu} / \mathrm{L})\end{array}$ & 30 & 140 & $\begin{array}{l}\text { Density } \\
(\mathrm{g} \mathrm{Pu} / \mathrm{L})\end{array}$ & 150 & $\begin{array}{l}\text { Density } \\
(\mathrm{g} \mathrm{Pu} / \mathrm{L})\end{array}$ & 200 & & \\
\hline $\begin{array}{l}\text { Volume } \\
\text { (L) }\end{array}$ & 20.625 & 10.678 & $\begin{array}{l}\text { Linear density }{ }^{a} \\
(\mathrm{~kg} \mathrm{Pu} / \mathrm{m})\end{array}$ & 3.766 & $\begin{array}{l}\text { Areal density } \\
\left(\mathrm{kg} \mathrm{Pu} / \mathrm{m}^{2}\right)\end{array}$ & 14.300 & & \\
\hline $\begin{array}{l}\text { Mass } \\
(\mathrm{kg} \mathrm{Pu})\end{array}$ & 0.618 & 1.495 & & & & & & \\
\hline \multicolumn{9}{|c|}{$\mathrm{Pu}(90,5,5,0)\left(\mathrm{NO}_{3}\right)_{4}$} \\
\hline \multicolumn{3}{|c|}{ Sphere } & \multicolumn{2}{|c|}{ Cylinder } & \multicolumn{2}{|l|}{ Slab } & \multicolumn{2}{|c|}{ Concentration } \\
\hline & $\begin{array}{l}\text { Min. } \\
\text { mass }\end{array}$ & $\begin{array}{l}\text { Min. } \\
\text { vol. }\end{array}$ & & $\begin{array}{c}\text { Min. } \\
\text { values }\end{array}$ & & $\begin{array}{c}\text { Min. } \\
\text { values }\end{array}$ & $(\mathrm{g} \mathrm{Pu} / \mathrm{L})$ & $(\mathrm{H} / \mathrm{Pu})$ \\
\hline $\begin{array}{l}\text { Radius } \\
(\mathrm{cm})\end{array}$ & 16.41 & 13.47 & $\begin{array}{l}\text { Diameter } \\
(\mathrm{cm})\end{array}$ & 17.60 & $\begin{array}{l}\text { Thickness } \\
\text { (cm) }\end{array}$ & 6.96 & 7.6 & 3,505 \\
\hline $\begin{array}{l}\text { Density } \\
(\mathrm{g} \mathrm{Pu} / \mathrm{L})\end{array}$ & 32 & 150 & $\begin{array}{l}\text { Density } \\
(\mathrm{g} \mathrm{Pu} / \mathrm{L})\end{array}$ & 150 & $\begin{array}{l}\text { Density } \\
(\mathrm{g} \mathrm{Pu} / \mathrm{L})\end{array}$ & 225 & & \\
\hline $\begin{array}{l}\text { Volume } \\
\text { (L) }\end{array}$ & 18.511 & 10.245 & $\begin{array}{l}\text { Linear density } \\
(\mathrm{kg} \mathrm{Pu} / \mathrm{m})\end{array}$ & 3.649 & $\begin{array}{l}\text { Areal density }{ }^{b} \\
\left(\mathrm{~kg} \mathrm{Pu} / \mathrm{m}^{2}\right)\end{array}$ & 15.660 & & \\
\hline $\begin{array}{l}\text { Mass } \\
(\mathrm{kg} \mathrm{Pu})\end{array}$ & 0.572 & 1.537 & & & & & & \\
\hline
\end{tabular}


Table 4 (continued)

\begin{tabular}{|c|c|c|c|c|c|c|c|c|}
\hline \multicolumn{9}{|c|}{$\mathrm{Pu}(80,10,10,0)\left(\mathrm{NO}_{3}\right)_{4}$} \\
\hline \multicolumn{3}{|c|}{ Sphere } & \multicolumn{2}{|l|}{ Cylinder } & \multicolumn{2}{|l|}{ Slab } & \multicolumn{2}{|c|}{ Concentration } \\
\hline & Min. mass & Min. vol. & & $\begin{array}{l}\text { Min. } \\
\text { values }\end{array}$ & & $\begin{array}{l}\text { Min. } \\
\text { values }\end{array}$ & $(\mathrm{g} \mathrm{Pu} / \mathrm{L})$ & $(\mathrm{H} / \mathrm{Pu})$ \\
\hline $\begin{array}{l}\text { Radius } \\
(\mathrm{cm})\end{array}$ & 17.59 & 14.22 & $\begin{array}{l}\text { Diameter } \\
(\mathrm{cm})\end{array}$ & 18.71 & $\begin{array}{l}\text { Thickness } \\
\text { (cm) }\end{array}$ & 7.65 & 8.05 & 3291 \\
\hline $\begin{array}{l}\text { Density } \\
(\mathrm{g} \mathrm{Pu} / \mathrm{L})\end{array}$ & 30 & 140 & $\begin{array}{l}\text { Density } \\
(\mathrm{g} \mathrm{Pu} / \mathrm{L})\end{array}$ & 150 & $\begin{array}{l}\text { Density } \\
(\mathrm{g} \mathrm{Pu} / \mathrm{L})\end{array}$ & 200 & & \\
\hline $\begin{array}{l}\text { Volume } \\
\text { (L) }\end{array}$ & 22.790 & 12.057 & $\begin{array}{l}\text { Linear density } \\
(\mathrm{kg} \mathrm{Pu} / \mathrm{m})\end{array}$ & 4.124 & $\begin{array}{l}\text { Areal density } \\
\left(\mathrm{kg} \mathrm{Pu} / \mathrm{m}^{2}\right)\end{array}$ & 15.300 & & \\
\hline $\begin{array}{l}\text { Mass } \\
(\mathrm{kg} \mathrm{Pu})\end{array}$ & 0.683 & 1.688 & & & & & & \\
\hline \multicolumn{9}{|c|}{$\mathrm{Pu}(71,17,11,1)\left(\mathrm{NO}_{3}\right)_{4}$} \\
\hline \multicolumn{3}{|c|}{ Sphere } & \multicolumn{2}{|c|}{ Cylinder } & \multicolumn{2}{|l|}{ Slab } & \multicolumn{2}{|c|}{ Concentration } \\
\hline & Min. mass & Min. vol. & & $\begin{array}{c}\text { Min. } \\
\text { values }\end{array}$ & & $\begin{array}{c}\text { Min. } \\
\text { values }\end{array}$ & $(\mathrm{g} \mathrm{Pu} / \mathrm{L})$ & $(\mathrm{H} / \mathrm{Pu})$ \\
\hline $\begin{array}{l}\text { Radius } \\
(\mathrm{cm})\end{array}$ & 18.16 & 15.52 & $\begin{array}{l}\text { Diameter } \\
(\mathrm{cm})\end{array}$ & 20.65 & $\begin{array}{l}\text { Thickness } \\
(\mathrm{cm})\end{array}$ & 8.88 & 9.15 & 2897 \\
\hline $\begin{array}{l}\text { Density } \\
(\mathrm{g} \mathrm{Pu} / \mathrm{L})\end{array}$ & 36 & 125 & $\begin{array}{l}\text { Density } \\
(\mathrm{g} \mathrm{Pu} / \mathrm{L})\end{array}$ & 135 & $\begin{array}{l}\text { Density } \\
(\mathrm{g} \mathrm{Pu} / \mathrm{L})\end{array}$ & 175 & & \\
\hline $\begin{array}{l}\text { Volume } \\
\text { (L) }\end{array}$ & 25.098 & 15.645 & $\begin{array}{l}\text { Linear density }{ }^{a} \\
(\mathrm{~kg} \mathrm{Pu} / \mathrm{m})\end{array}$ & 4.521 & $\begin{array}{l}\text { Areal density } \\
\left(\mathrm{kg} \mathrm{Pu} / \mathrm{m}^{2}\right)\end{array}$ & 15.540 & & \\
\hline $\begin{array}{l}\text { Mass } \\
(\mathrm{kg} \mathrm{Pu})\end{array}$ & 0.902 & 1.956 & & & & & & \\
\hline
\end{tabular}

${ }^{a}$ Linear density (cylinders): density $(\mathrm{g} \mathrm{Pu} / \mathrm{L}) *(\pi / 4)\left(\mathrm{d}^{2}\right) * 10^{-4}=\mathrm{kg} \mathrm{Pu} / \mathrm{m}, \mathrm{d}=$ diameter.

${ }^{b}$ Areal density (slab): density $(\mathrm{g} \mathrm{Pu} / \mathrm{L}) * \mathrm{t} * 10^{-2}=\mathrm{kg} \mathrm{Pu} / \mathrm{m}^{2}, \mathrm{t}=$ thickness. 


\subsection{RANGE OF DATA AND DISCREPANCIES}

Tables 5 and 6 give an overview on the largest and smallest values found for every minimum critical parameter of the examined $\mathrm{UO}_{2}, \mathrm{UHN}, \mathrm{PuO}_{2}$, and $\mathrm{PuNH}$ systems as reported by W. Weber and D. Mennerdahl in "Results of an OECD/NEA Comparison of Minimum Critical Values," which was presented at The Seventh International Conference on Nuclear Criticality Safety (ICNC2003), Tokaimura, Japan, October 20-24, 2003 (ref. 1). ORNL results are shown in comparison to the Weber report. To identify discrepancies of major size, the percentage differences $\left(\Delta_{\text {all }}\right)$ between the largest and the smallest value for every critical parameter for all systems of the compilation are given. 
Table 5. Spheres: largest and smallest minimum critical values and differences $\left(\Delta_{\text {all }}\right)$ for all entries provided

\begin{tabular}{|c|c|c|c|c|c|c|c|c|}
\hline \multicolumn{9}{|c|}{$\mathrm{UO}_{2}$ systems } \\
\hline \multicolumn{5}{|c|}{ Sphere mass (kg U) } & \multicolumn{4}{|c|}{ Sphere volume (L) } \\
\hline${ }^{235} \mathrm{U}(\mathrm{wt} \%)$ & $\begin{array}{l}\text { Smallest, } \\
\text { all }\end{array}$ & ORNL & $\begin{array}{c}\text { Largest, } \\
\text { all }\end{array}$ & $\Delta_{\text {all }}(\%)$ & $\begin{array}{c}\text { Smallest, } \\
\text { all }\end{array}$ & ORNL & $\begin{array}{c}\text { Largest, } \\
\text { all }\end{array}$ & $\Delta_{\text {all }}(\%)$ \\
\hline 3 & 88 & 101.8 & 102.8 & 14 & 45 & 53.9 & 55.8 & 19 \\
\hline 4 & 53.9 & 54.8 & 56.9 & 5 & 32.9 & 35.9 & 37 & 11 \\
\hline 5 & 35 & 38.2 & 38.2 & 8 & 27.4 & 27.9 & 29.1 & 6 \\
\hline 20 & 4.95 & 5.2 & 7.43 & 33 & 9.9 & 10.7 & 11.5 & 14 \\
\hline 100 & 0.77 & 0.79 & 0.84 & 8 & 3.9 & 4.3 & 6.1 & 36 \\
\hline \multicolumn{9}{|c|}{ UHN systems } \\
\hline \multicolumn{5}{|c|}{ Sphere mass (kg U) } & \multicolumn{4}{|c|}{ Sphere volume (L) } \\
\hline${ }^{235} \mathrm{U}(\mathrm{wt} \%)$ & $\begin{array}{l}\text { Smallest, } \\
\text { all }\end{array}$ & ORNL & $\begin{array}{c}\text { Largest, } \\
\text { all }\end{array}$ & $\Delta_{\text {all }}(\%)$ & $\begin{array}{c}\text { Smallest, } \\
\text { all }\end{array}$ & ORNL & $\begin{array}{c}\text { Largest, } \\
\text { all }\end{array}$ & $\Delta_{\text {all }}(\%)$ \\
\hline 3 & 429 & 491 & 529 & 19 & 361 & 405 & 434 & 17 \\
\hline 4 & 144.2 & 149.1 & 164 & 12 & 134.9 & 146.3 & 160 & 16 \\
\hline 5 & 74 & 76.8 & 82.2 & 10 & 80 & 86.1 & 89.4 & 11 \\
\hline 20 & 4 & 6.0 & 6.13 & 35 & 15 & 16.3 & 16.93 & 11 \\
\hline 100 & 0.79 & 0.808 & 0.86 & 8 & 6.38 & 6.8 & 7 & 9 \\
\hline \multicolumn{9}{|c|}{$\mathrm{PuO}_{2}$ systems } \\
\hline \multicolumn{5}{|c|}{ Sphere mass $(\mathrm{kg} \mathrm{Pu})$} & \multicolumn{4}{|c|}{ Sphere volume (L) } \\
\hline $\begin{array}{l}\mathrm{Pu} \text { vector: } \\
{ }^{239} \mathrm{Pu},{ }^{240} \mathrm{Pu}, \\
{ }^{241} \mathrm{Pu},{ }^{242} \mathrm{Pu}\end{array}$ & $\begin{array}{c}\text { Smallest, } \\
\text { all }\end{array}$ & ORNL & $\begin{array}{c}\text { Largest }, \\
\text { all }\end{array}$ & $\Delta_{\text {all }}(\%)$ & $\begin{array}{c}\text { Smallest, } \\
\text { all }\end{array}$ & ORNL & $\begin{array}{c}\text { Largest, } \\
\text { all }\end{array}$ & $\Delta_{\text {all }}(\%)$ \\
\hline $100 / 0 / 0 / 0$ & 0.48 & 0.497 & 0.531 & 10 & 1.00 & 1.144 & 1.22 & 18 \\
\hline $95 / 5 / 0 / 0$ & 0.58 & 0.602 & 0.65 & 10 & 1.23 & 1.227 & 1.31 & 6 \\
\hline $90 / 5 / 5 / 0$ & 0.585 & 0.577 & - & - & 1.24 & 1.217 & - & - \\
\hline $80 / 10 / 10 / 0$ & 0.665 & 0.665 & 0.715 & 7 & 1.28 & 1.279 & 1.36 & 6 \\
\hline 71/17/11/1 & 0.88 & 0.88 & 0.95 & 8 & 1.40 & 1.4 & 1.5 & 6 \\
\hline \multicolumn{9}{|c|}{ PuHN systems } \\
\hline \multicolumn{5}{|c|}{ Sphere mass $(\mathrm{kg} \mathrm{Pu})$} & \multicolumn{4}{|c|}{ Sphere volume (L) } \\
\hline $\begin{array}{l}\text { Pu vector: } \\
{ }^{239} \mathrm{Pu},{ }^{240} \mathrm{Pu}, \\
{ }^{241} \mathrm{Pu},{ }^{242} \mathrm{Pu}\end{array}$ & $\begin{array}{l}\text { Smallest, } \\
\text { all }\end{array}$ & ORNL & $\begin{array}{c}\text { Largest }, \\
\text { all }\end{array}$ & $\Delta_{\text {all }}(\%)$ & $\begin{array}{c}\text { Smallest, } \\
\text { all }\end{array}$ & ORNL & $\begin{array}{c}\text { Largest, } \\
\text { all }\end{array}$ & $\Delta_{\text {all }}(\%)$ \\
\hline $100 / 0 / 0 / 0$ & 0.509 & 0.509 & 0.544 & 6 & 7.256 & 7.564 & 8.3 & 13 \\
\hline $95 / 5 / 0 / 0$ & 0.61 & 0.618 & 0.663 & 8 & 10.67 & 10.678 & 11.45 & 7 \\
\hline $90 / 5 / 5 / 0$ & 0.598 & 0.572 & 0.60 & 0.3 & 10.175 & 10.245 & 10.27 & 1 \\
\hline $80 / 10 / 10 / 0$ & 0.66 & 0.683 & 0.735 & 10 & 11.8 & 12.057 & 12.96 & 9 \\
\hline $71 / 17 / 11 / 1$ & 0.90 & 0.902 & 0.978 & 8 & 15.6 & 15.645 & 16.92 & 8 \\
\hline
\end{tabular}


Table 6. Cylinders and slabs: largest and smallest minimum critical values and differences $\left(\Delta_{\text {all }}\right)$ for all entries provided

\begin{tabular}{|c|c|c|c|c|c|c|c|c|c|c|c|c|}
\hline \multicolumn{13}{|c|}{$\mathrm{UO}_{2}$ systems } \\
\hline \multicolumn{5}{|c|}{ Cylinder diameter $(\mathrm{cm})$} & \multicolumn{4}{|c|}{ Slab thickness $(\mathrm{cm})$} & \multicolumn{4}{|c|}{ Concentration (g U/L) } \\
\hline${ }^{235} \mathrm{U}(\mathrm{wt} \%)$ & $\begin{array}{c}\text { Smallest, } \\
\text { all }\end{array}$ & ORNL & $\begin{array}{c}\text { Largest, } \\
\text { all } \\
\end{array}$ & $\begin{array}{l}\Delta_{\text {all }} \\
(\%)\end{array}$ & $\begin{array}{c}\text { Smallest, } \\
\text { all }\end{array}$ & ORNL & $\begin{array}{c}\text { Largest, } \\
\text { all }\end{array}$ & $\begin{array}{l}\Delta_{\text {all }} \\
(\%)\end{array}$ & $\begin{array}{c}\text { Smallest, } \\
\text { all }\end{array}$ & ORNL & $\begin{array}{c}\text { Largest, } \\
\text { all }\end{array}$ & $\begin{array}{l}\Delta_{\text {all }} \\
(\%)\end{array}$ \\
\hline 3 & 30.7 & 32.7 & 33.2 & 8 & 15.5 & 16.7 & 17 & 9 & 499 & 521 & 538 & 7 \\
\hline 4 & 27.6 & 28.2 & 28.6 & 4 & 13.4 & 13.8 & 14 & 4 & 356 & 369.4 & 400 & 11 \\
\hline 5 & 24.9 & 25.7 & 26.1 & 5 & 11.9 & 12.2 & 12.4 & 4 & 270 & 286.6 & 296 & 9 \\
\hline 20 & 17.3 & 17.9 & 17.94 & 4 & 6.4 & 7.2 & 7.5 & 15 & 62.7 & 64.7 & 65.7 & 5 \\
\hline 100 & 12 & 12.4 & 14.3 & 16 & 3.3 & 3.4 & 4.9 & 33 & 11.7 & 12.17 & 13 & 10 \\
\hline \multicolumn{13}{|c|}{ UNH systems } \\
\hline \multicolumn{5}{|c|}{ Cylinder diameter $(\mathrm{cm})$} & \multicolumn{4}{|c|}{ Slab thickness $(\mathrm{cm})$} & \multicolumn{4}{|c|}{ Concentration $\mathrm{g} \mathrm{U} / \mathrm{L}$} \\
\hline${ }^{235} \mathrm{U}(\mathrm{wt} \%)$ & $\begin{array}{c}\text { Smallest, } \\
\text { all }\end{array}$ & ORNL & $\begin{array}{c}\text { Largest, } \\
\text { all }\end{array}$ & $\begin{array}{l}\Delta_{\text {all }} \\
(\%) \\
\end{array}$ & $\begin{array}{c}\text { Smallest, } \\
\text { all }\end{array}$ & ORNL & $\begin{array}{c}\text { Largest, } \\
\text { all }\end{array}$ & $\begin{array}{l}\Delta_{\text {all }} \\
(\%)\end{array}$ & $\begin{array}{c}\text { Smallest, } \\
\text { all }\end{array}$ & ORNL & $\begin{array}{c}\text { Largest, } \\
\text { all }\end{array}$ & $\begin{array}{l}\Delta_{\text {all }} \\
(\%)\end{array}$ \\
\hline 3 & 64.6 & 66.96 & 68.5 & 6 & 36.5 & 38.72 & 39.8 & 8 & 600 & 624.6 & 658 & 9 \\
\hline 4 & 45.18 & 46.89 & 47.9 & 6 & 24.98 & 25.77 & 26.22 & 5 & 356 & 415.5 & 421 & 15 \\
\hline 5 & 37.82 & 38.79 & 39.59 & 5 & 19.6 & 20.57 & 20.89 & 6 & 309.9 & 311.5 & 323 & 4 \\
\hline 20 & 20.92 & 21.04 & 21 & 1.3 & 9.18 & 9.24 & 9.33 & 1.6 & 64.6 & 65.0 & 68.8 & 6 \\
\hline 100 & 14.7 & 15.04 & 15.4 & 4.5 & 4.4 & 5.44 & 5.6 & 21 & 12.1 & 12.25 & 14.3 & 15 \\
\hline \multicolumn{13}{|c|}{$\mathrm{PuO}_{2}$ systems } \\
\hline \multicolumn{5}{|c|}{ Cylinder diameter $(\mathrm{cm})$} & \multicolumn{4}{|c|}{ Slab thickness $(\mathrm{cm})$} & \multicolumn{4}{|c|}{ Concentration $\mathrm{g} \mathrm{Pu} / \mathrm{L}$} \\
\hline $\begin{array}{l}\text { Pu-vector: } \\
{ }^{239} \mathrm{Pu},{ }^{240} \mathrm{Pu}, \\
{ }^{241} \mathrm{Pu},{ }^{242} \mathrm{Pu}\end{array}$ & $\begin{array}{c}\text { Smallest, } \\
\text { all }\end{array}$ & ORNL & $\begin{array}{l}\text { Largest, } \\
\text { all }\end{array}$ & $\begin{array}{l}\Delta_{\text {all }} \\
(\%)\end{array}$ & $\begin{array}{c}\text { Smallest, } \\
\text { all }\end{array}$ & ORNL & $\begin{array}{l}\text { Largest, } \\
\text { all }\end{array}$ & $\begin{array}{l}\Delta_{\text {all }} \\
(\%)\end{array}$ & $\begin{array}{l}\text { Smallest, } \\
\text { all }\end{array}$ & ORNL & $\begin{array}{l}\text { Largest, } \\
\text { all }\end{array}$ & $\begin{array}{l}\Delta_{\text {all }} \\
(\%)\end{array}$ \\
\hline $100 / 0 / 0 / 0$ & 7.3 & 7.667 & 7.82 & 7 & 1.7 & 1.723 & 1.83 & 7 & 7.1 & 7.091 & 7.7 & 8 \\
\hline$(95,5,5,0$ & 7.93 & 7.926 & 8.1 & 2 & 1.93 & 1.927 & 2.04 & 6 & 7.64 & 7.640 & 7.96 & 4 \\
\hline$(90,5,5,0)$ & 7.944 & 7.871 & - & - & 1.883 & 1.845 & - & - & 7.6 & 7.47 & - & - \\
\hline $80,10,10,0$ & 8.02 & 8.022 & 8.20 & 2 & 1.91 & 1.908 & 2.03 & 6 & 7.89 & 7.889 & 8.24 & 4 \\
\hline $71,17,11,1$ & 8.34 & 8.335 & 8.5 & 2 & 2.1 & 2.096 & 2.23 & 6 & 8.97 & 8.968 & 9.37 & 4 \\
\hline \multicolumn{13}{|c|}{ PuNH systems } \\
\hline \multicolumn{5}{|c|}{ Cylinder diameter $(\mathrm{cm})$} & \multicolumn{4}{|c|}{ Slab thickness $(\mathrm{cm})$} & \multicolumn{4}{|c|}{ Concentration $\mathrm{g} \mathrm{Pu} / \mathrm{L}$} \\
\hline $\begin{array}{l}\text { Pu vector: } \\
{ }^{239} \mathrm{Pu},{ }^{240} \mathrm{Pu} \text {, } \\
{ }^{241} \mathrm{Pu},{ }^{242} \mathrm{Pu}\end{array}$ & $\begin{array}{c}\text { Smallest, } \\
\text { all }\end{array}$ & ORNL & $\begin{array}{l}\text { Largest, } \\
\text { all }\end{array}$ & $\begin{array}{l}\Delta_{\text {all }} \\
(\%)\end{array}$ & $\begin{array}{c}\text { Smallest, } \\
\text { all }\end{array}$ & ORNL & $\begin{array}{l}\text { Largest, } \\
\text { all }\end{array}$ & $\begin{array}{l}\Delta_{\text {all }} \\
(\%)\end{array}$ & $\begin{array}{l}\text { Smallest, } \\
\text { all }\end{array}$ & ORNL & $\begin{array}{l}\text { Largest, } \\
\text { all }\end{array}$ & $\begin{array}{l}\Delta_{\text {all }} \\
(\%)\end{array}$ \\
\hline $100 / 0 / 0 / 0$ & 15.4 & 15.63 & 16.2 & 5 & 5.522 & 5.68 & 6.2 & 11 & 7.2 & 7.21 & 7.7 & 7 \\
\hline$(95,5,5,0$ & 17.2 & 17.88 & 18.7 & 8 & 6.9 & 7.15 & 7.5 & 8 & 7.77 & 7.77 & 8.01 & 3 \\
\hline$(90,5,5,0)$ & 17.564 & 17.60 & 17.64 & 0.4 & 6.904 & 6.96 & 7.04 & 2 & 7.6 & 7.6 & 7.64 & 0.5 \\
\hline $80,10,10,0$ & 18.686 & 18.71 & 19.2 & 3 & 7.471 & 7.65 & 8.03 & 7 & 8 & 8.05 & 8.3 & 4 \\
\hline $71,17,11,1$ & 20.65 & 20.65 & 21.24 & 3 & 8.777 & 8.88 & 9.32 & 6 & 8.8 & 9.15 & 10.27 & 14 \\
\hline
\end{tabular}




\section{CONCLUSIONS}

Basic minimum critical values are important physical constants needed for assessing safety margins in criticality and are used for licensing. The scope of the Expert Group is to compile minimum critical values from different countries. Some of the members use identical or almost identical methods and data.

The built-in SCALE atomic number density equations for uranyl nitrate (UNH) and plutonium nitrate $(\mathrm{PuNH})$ were used. The maximum uranium density is about $1296 \mathrm{~g} / \mathrm{L}$. In the calculations for $3 \mathrm{wt} \%$ enriched uranium nitrate, the uranium density for minimum values was higher than what a real solution would support. Therefore, a great deal of confidence should not be placed in the results above the uranium density of $1296 \mathrm{~g} / \mathrm{L}$. SCALE warns the user when the uranium density is higher than what a real solution would support. 



\section{REFERENCES}

1. W. Weber and D. Mennerdahl, "Results of an OECD/NEA Comparison of Minimum Critical Values," in Proceedings of the Seventh International Conference on Nuclear Criticality Safety, JAERI-Conf 2003-019, Japan Atomic Energy Research Institute, Tokai-mura, Japan, 2003.

2. SCALE: A Modular Code System for Performing Standardized Computer Analyses for Licensing Evaluation, NUREG/CR-0200, Rev. 6 (ORNL/NUREG/CSD-2/R6), Vols. I, II, and III, May 2000. Available from Radiation Safety Information Computational Center at Oak Ridge National Laboratory as CCC-545.

3. N. M. Greene, J. W. Arwood, R. Q. Wright, and C. V. Parks, The LAW Library-A Multigroup Cross-Section Library for Use in Radioactive Waste Analysis Calculations, ORNL/TM-12370, Martin Marietta Energy Systems, Oak Ridge National Laboratory, August 1994.

4. S. M. Bowman, W. C. Jordan, J. F. Mincey, C. V. Parks, and L. M. Petrie, Experience with the Scale Criticality Safety Cross-Section Libraries, NUREG/CR-6686 (ORNL/TM-1999/322), U.S. Nuclear Regulatory Commission, Oak Ridge National Laboratory, October 2000.

5. N. M. Greene, W. E. Ford III, L. M. Petrie, and J. W. Arwood, AMPX-77: A Modular Code System for Generating Coupled Multigroup Neutron-Gamma Cross-Section Libraries from ENDF/B-IV and/or ENDF/B-V, ORNL/CSD/TM-283, Martin Marietta Energy Systems, Oak Ridge National Laboratory, October 1992.

6. R. D. Carter, G. R. Kiel, and K. R. Ridgway, Criticality Handbook Volume I, ARH-600, Atlantic Richfield Hanford Co., June 1968.

7. E. R. Cohen and B. N. Taylor, "The Fundamental Physical Constants," Physics Today 45(8), 9-13 (1992). 

APPENDIX A

GRAPHS OF $\mathrm{UO}_{2}-\mathrm{H}_{2} \mathrm{O}$, WATER REFLECTED $(30 \mathrm{~cm})$ : CRITICAL PARAMETERS VS FUEL VOLUME FRACTIONS 



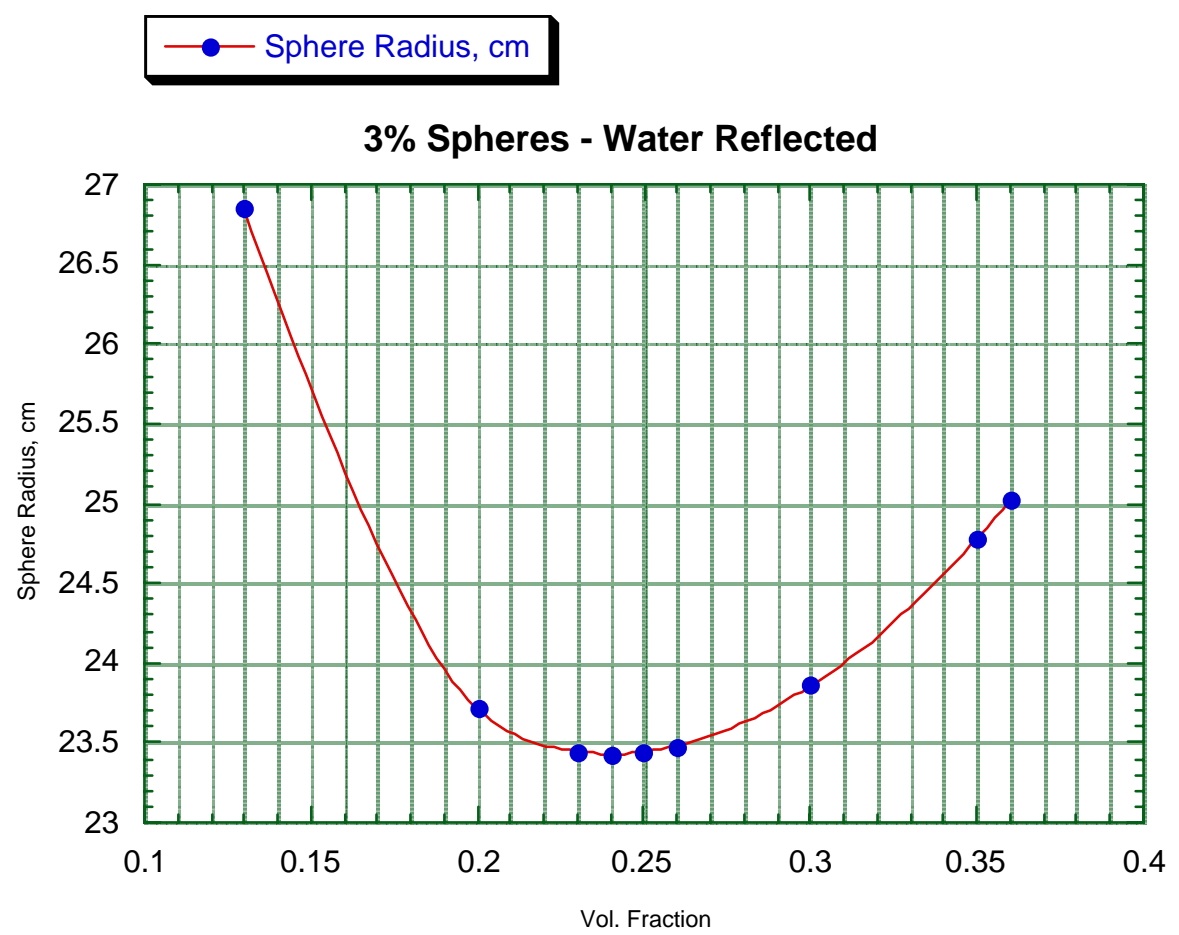

Fig. A.1. Radius vs volume fraction for $3 \%$ enriched $\mathrm{UO}_{2}-\mathrm{H}_{2} \mathrm{O}$ spheres.

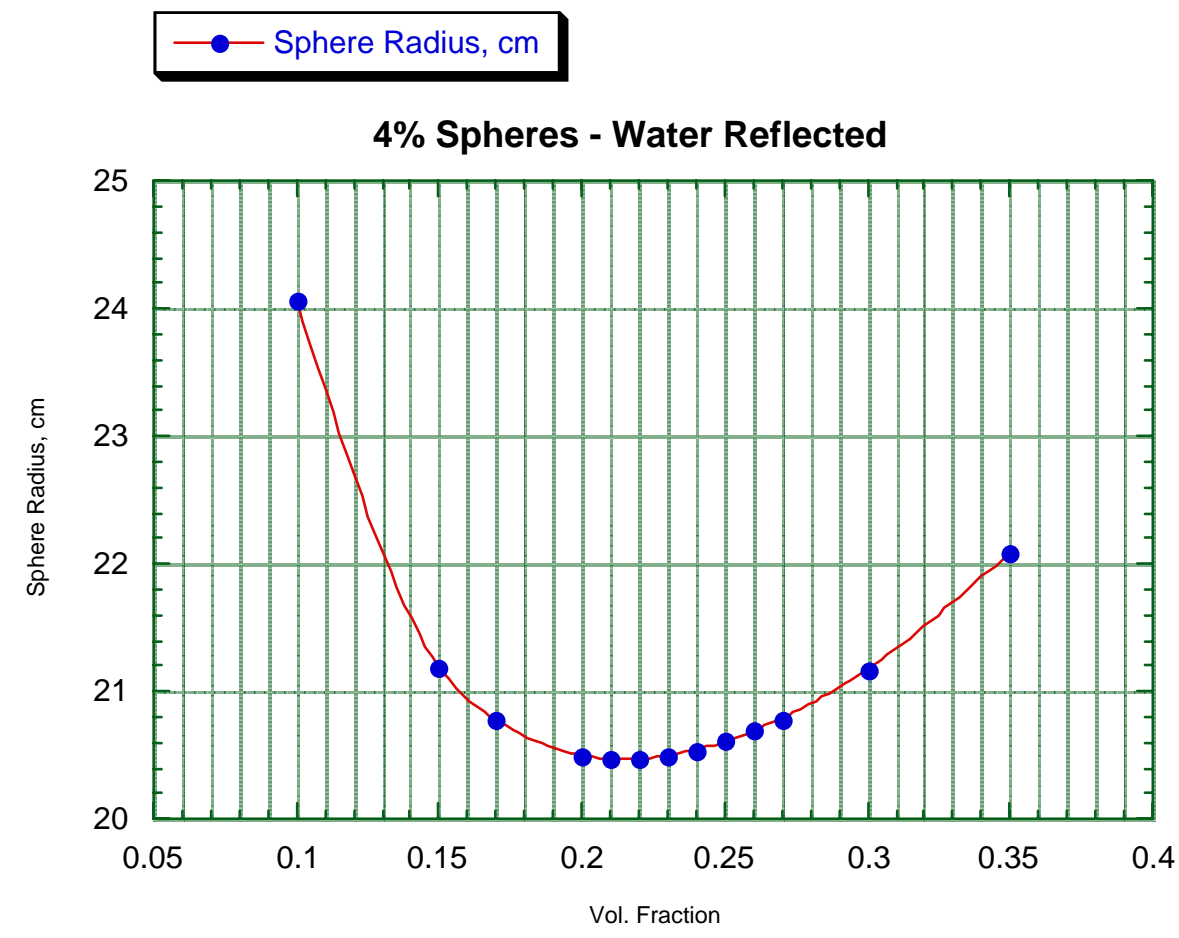

Fig. A.2. Radius vs volume fraction for $4 \%$ enriched $\mathrm{UO}_{2}-\mathrm{H}_{2} \mathrm{O}$ spheres. 


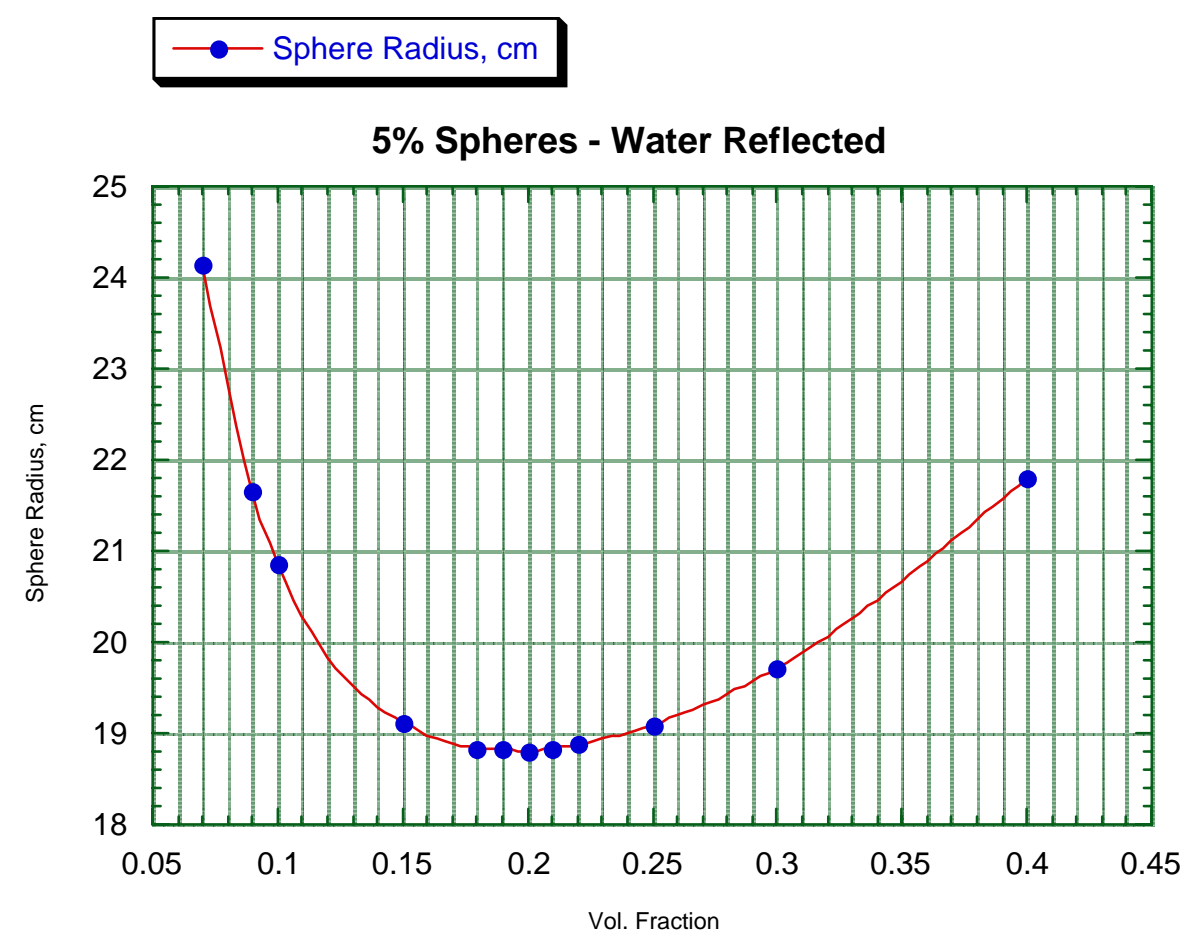

Fig. A.3. Radius vs volume fraction for $5 \%$ enriched $\mathrm{UO}_{2}-\mathrm{H}_{2} \mathrm{O}$ spheres.

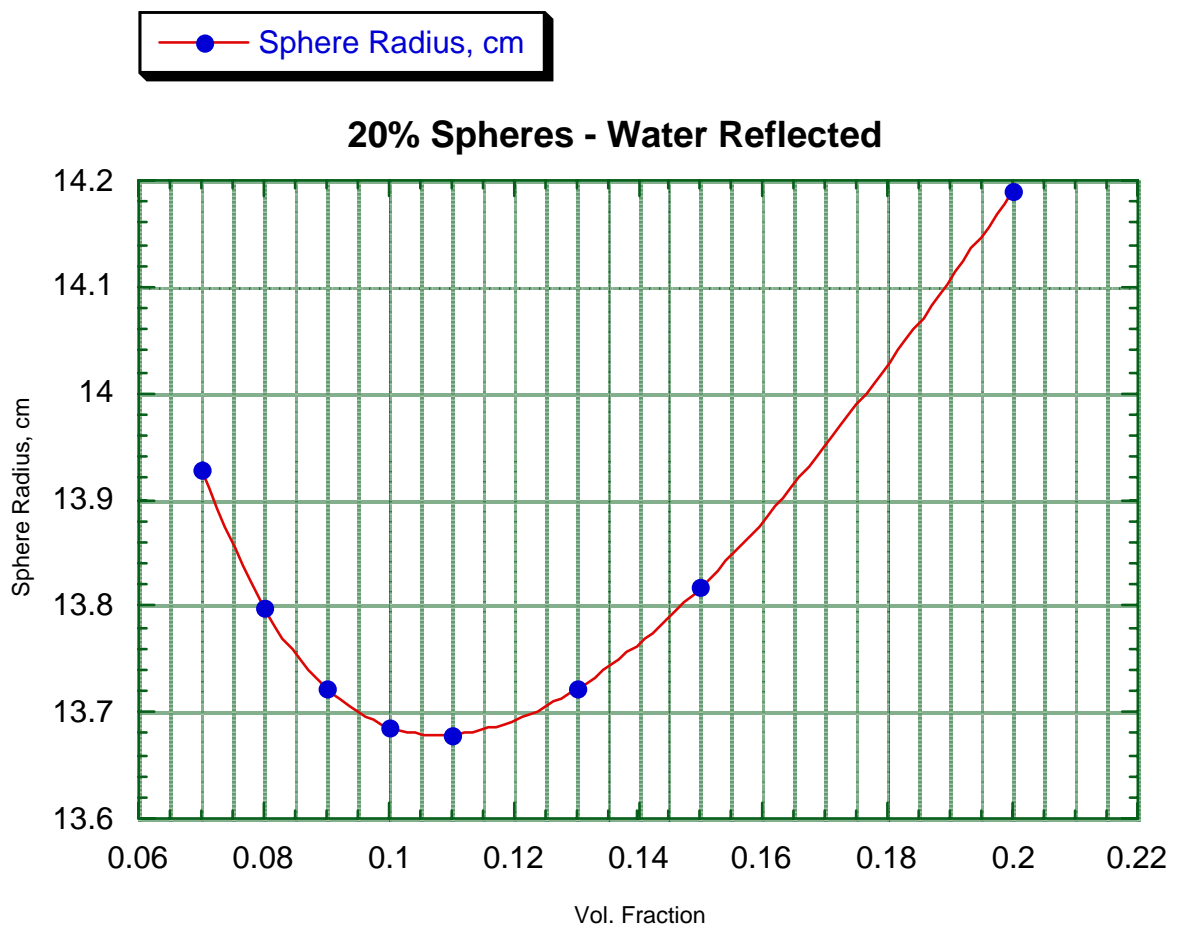

Fig. A.4. Radius vs volume fraction for $20 \%$ enriched $\mathrm{UO}_{2}-\mathrm{H}_{2} \mathrm{O}$ spheres. 


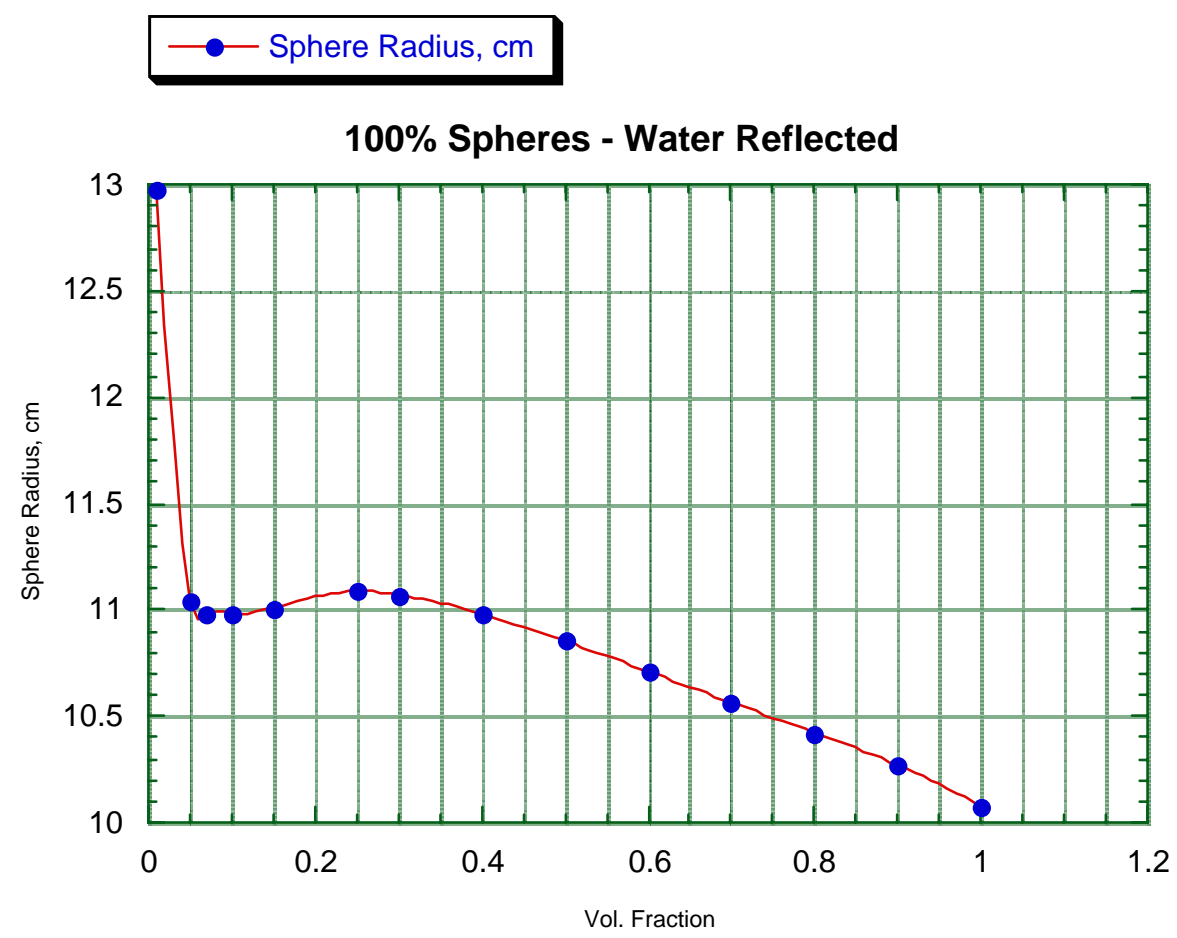

Fig. A.5. Radius vs volume fraction for $100 \%$ enriched $\mathrm{UO}_{2}-\mathrm{H}_{2} \mathrm{O}$ spheres. 


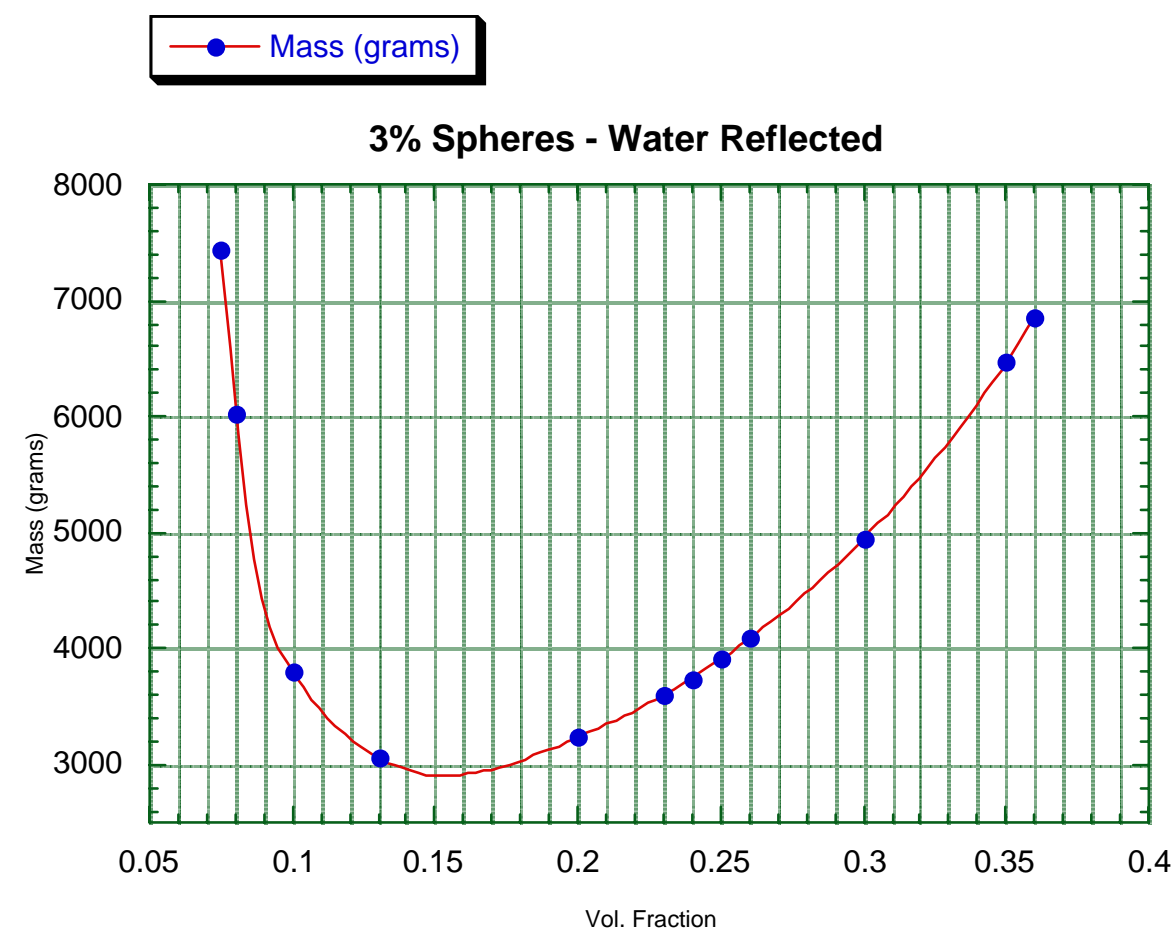

Fig. A.6. Mass vs volume fraction for $3 \%$ enriched $\mathrm{UO}_{2}-\mathrm{H}_{2} \mathrm{O}$ spheres.

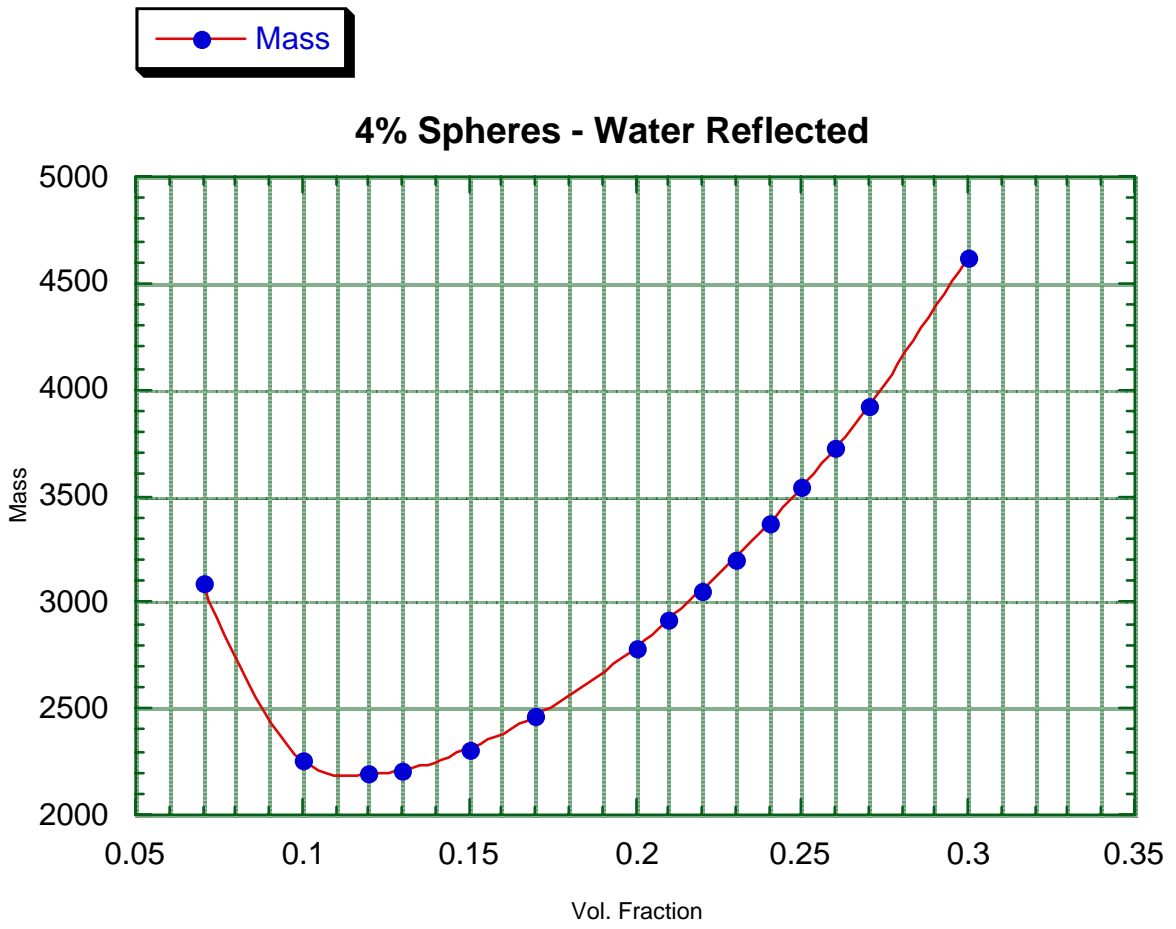

Fig. A.7. Mass vs volume fraction for $4 \%$ enriched $\mathrm{UO}_{2}-\mathrm{H}_{2} \mathrm{O}$ spheres. 


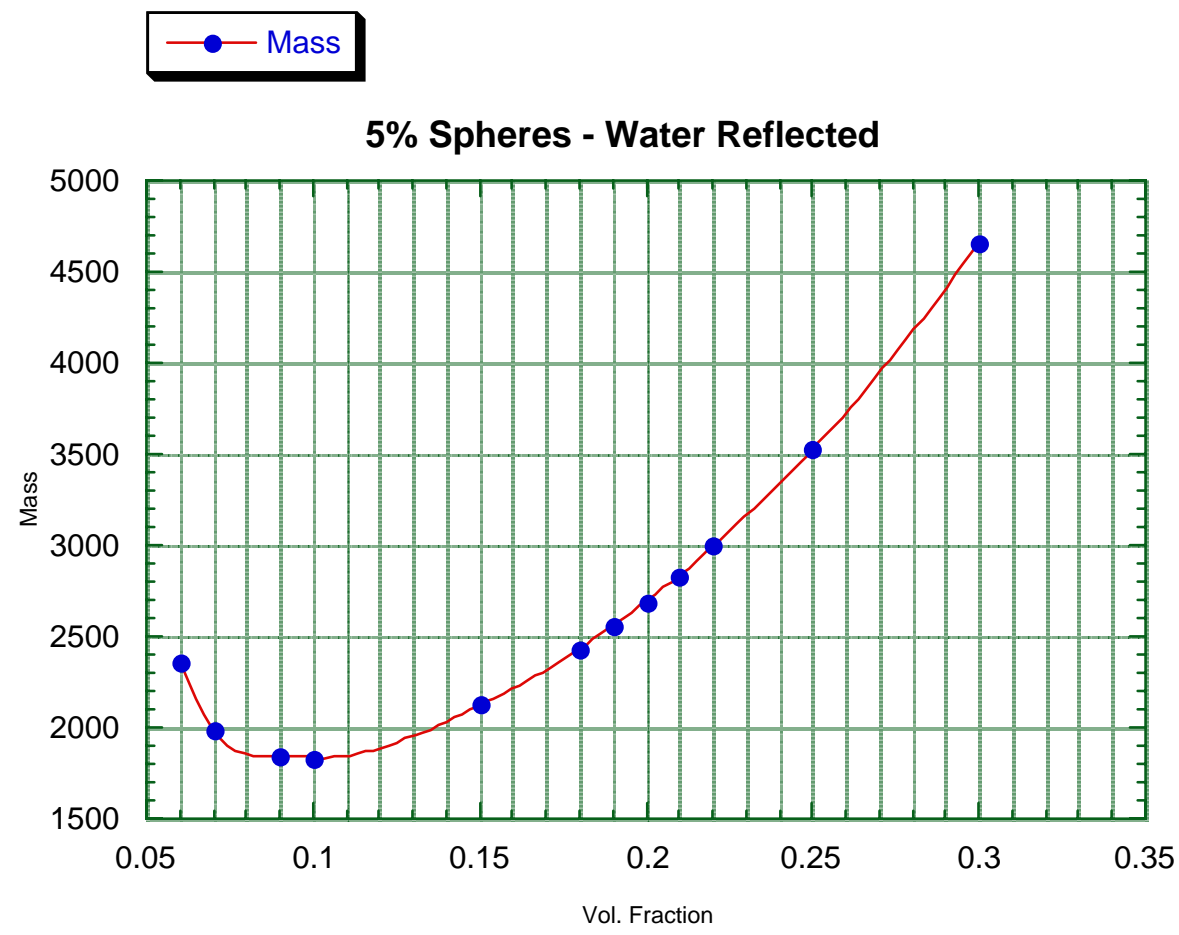

Fig. A.8. Mass vs volume fraction for $5 \%$ enriched $\mathrm{UO}_{2}-\mathrm{H}_{2} \mathrm{O}$ spheres.

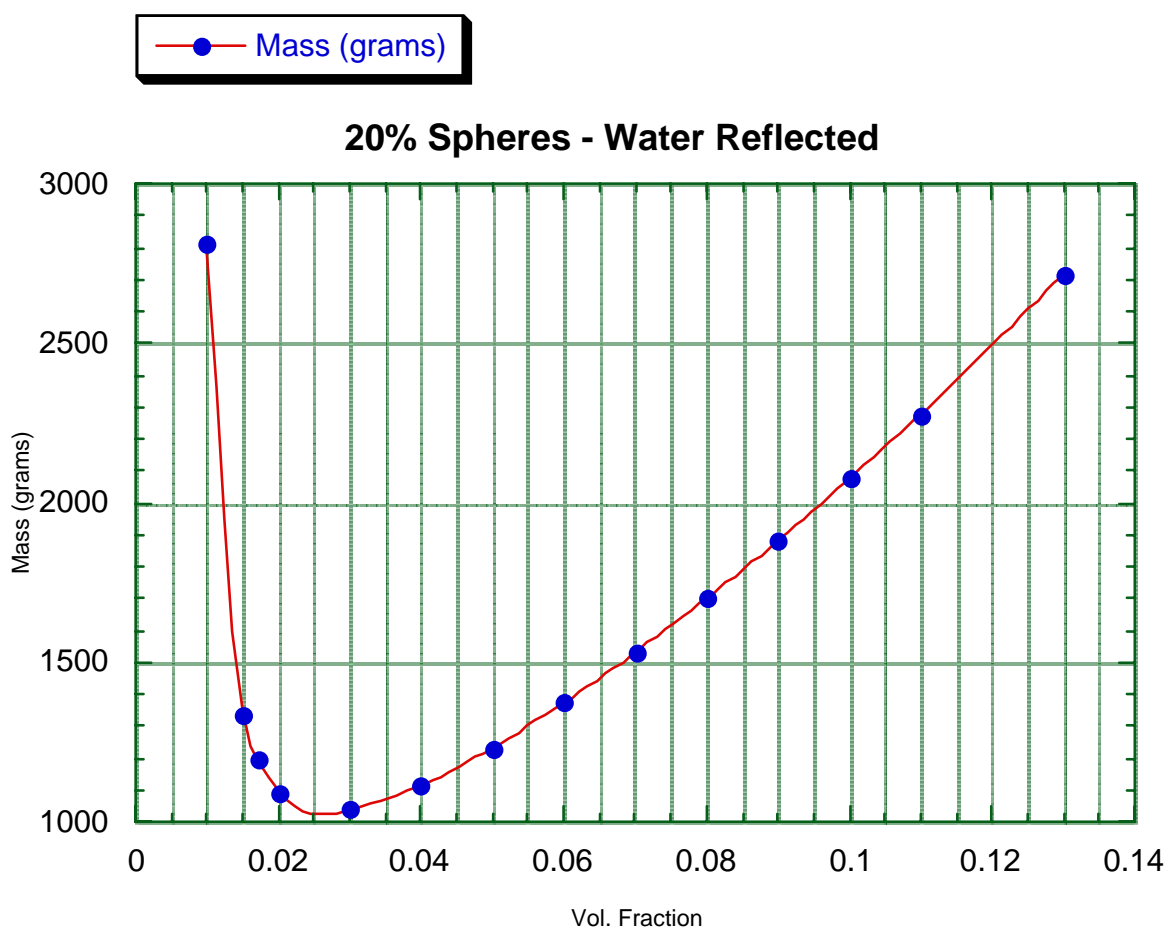

Fig. A.9. Mass vs volume fraction for $20 \%$ enriched $\mathrm{UO}_{2}-\mathrm{H}_{2} \mathrm{O}$ spheres. 


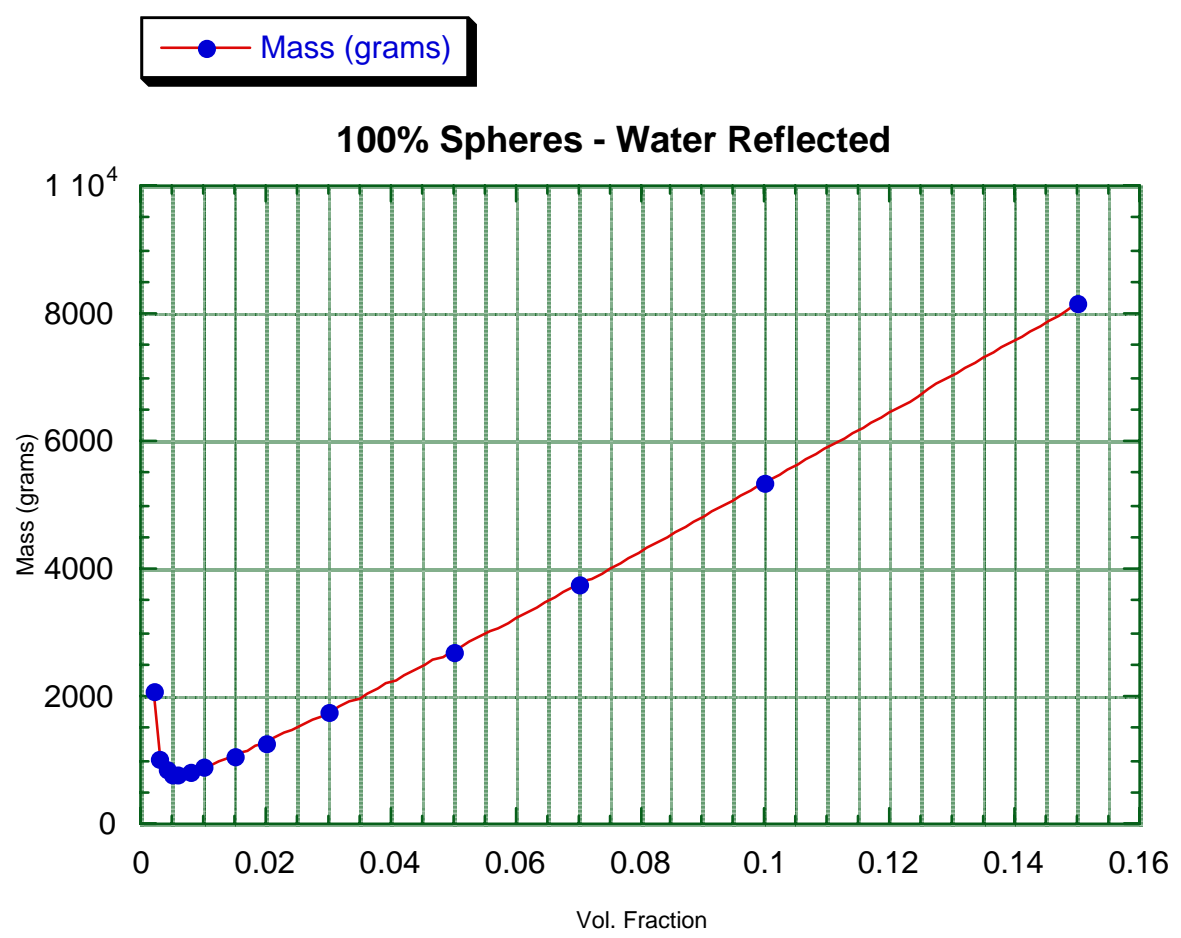

Fig. A.10. Mass vs volume fraction for $100 \%$ enriched $\mathrm{UO}_{2}-\mathrm{H}_{2} \mathrm{O}$ spheres. 


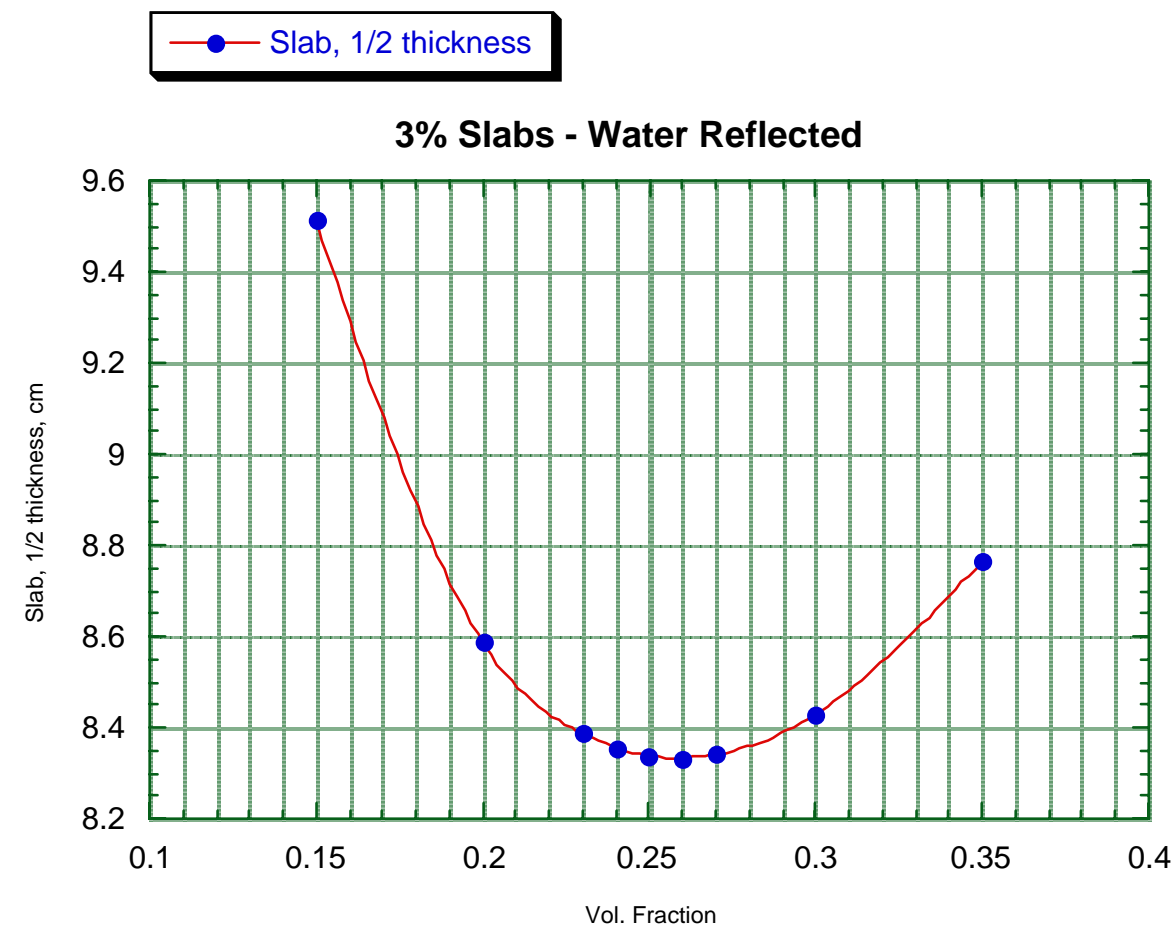

Fig. A.11. One-half thickness vs volume fraction for $3 \%$ enriched $\mathrm{UO}_{2}-\mathrm{H}_{2} \mathrm{O}$ slabs.

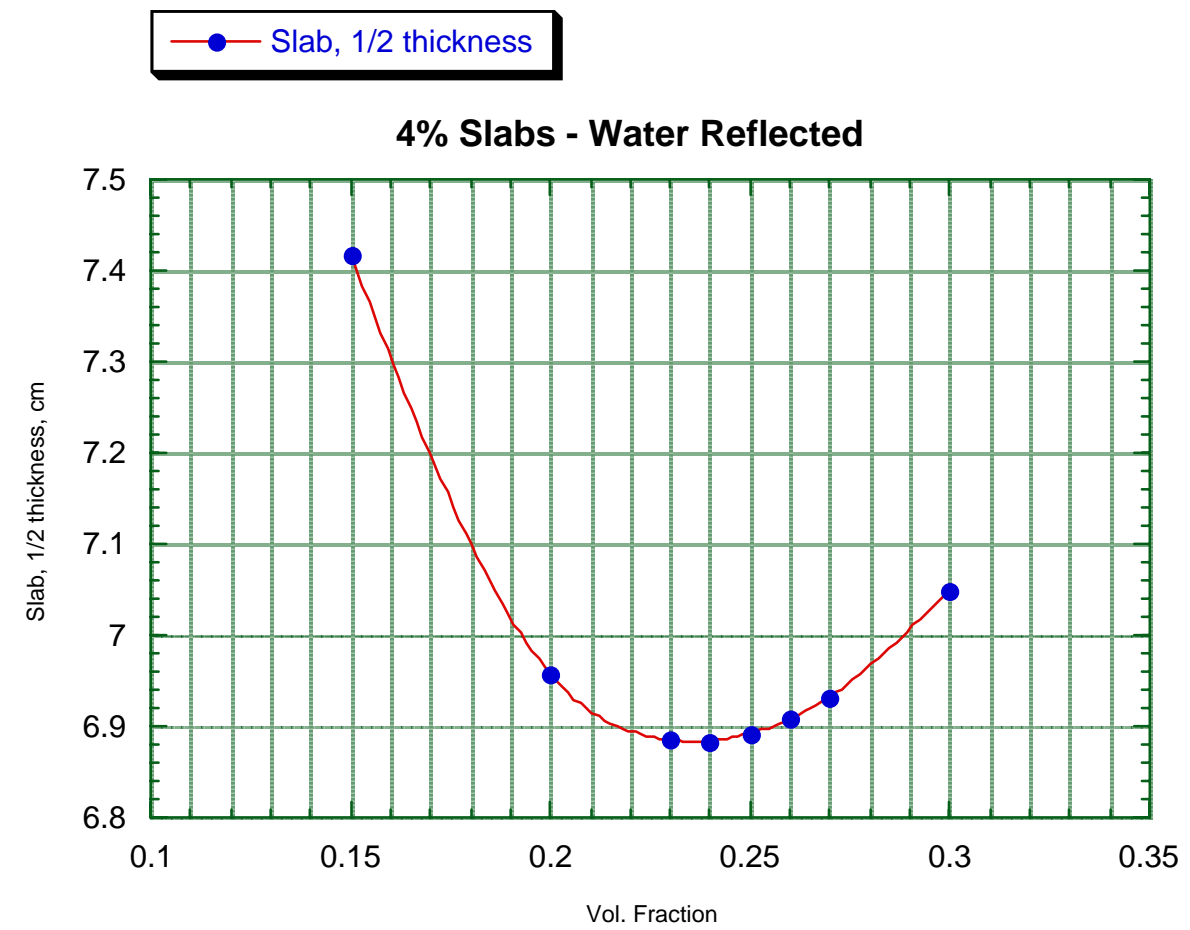

Fig. A.12. One-half thickness vs volume fraction for $4 \%$ enriched $\mathrm{UO}_{2}-\mathrm{H}_{2} \mathrm{O}$ slabs. 


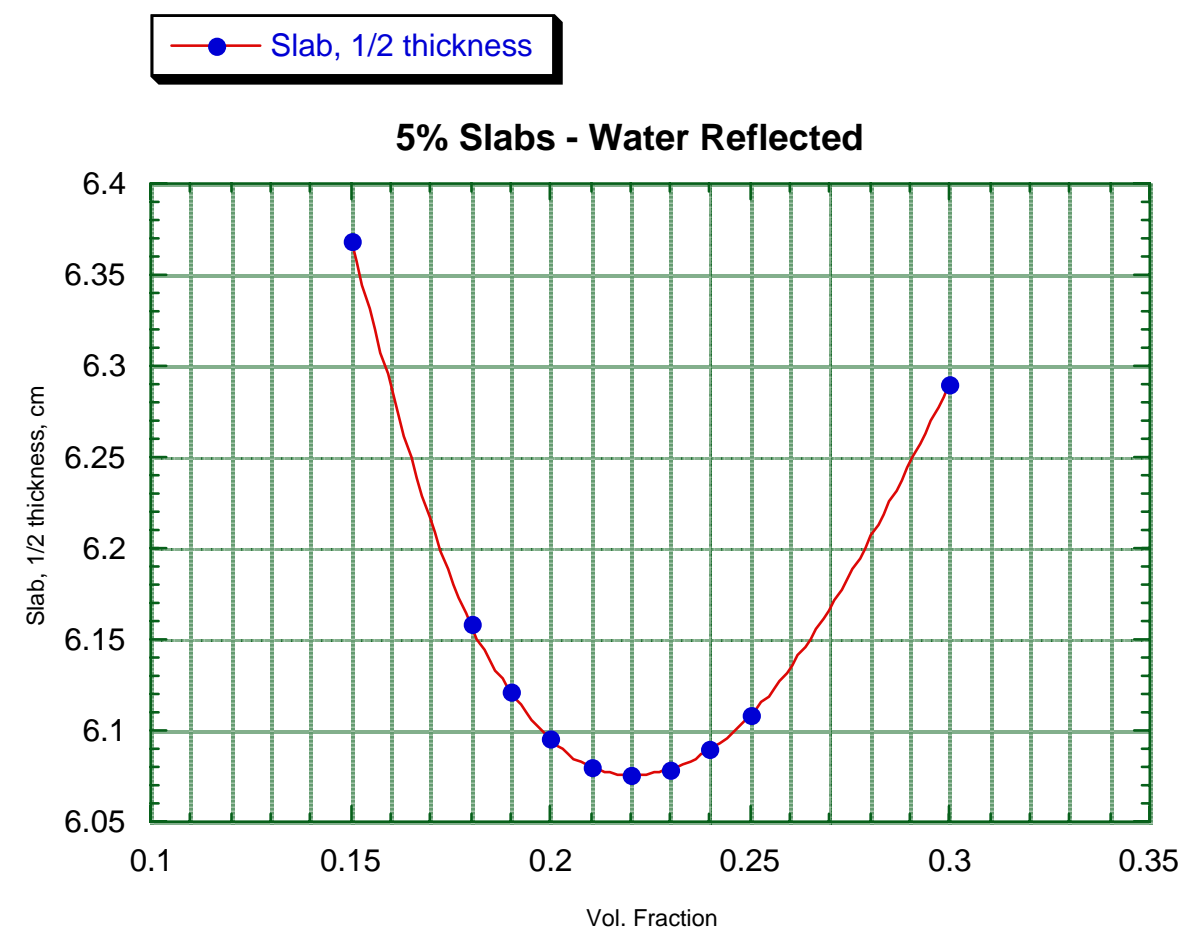

Fig. A.13. One-half thickness vs volume fraction for $5 \%$ enriched $\mathrm{UO}_{2}-\mathrm{H}_{2} \mathrm{O}$ slabs.

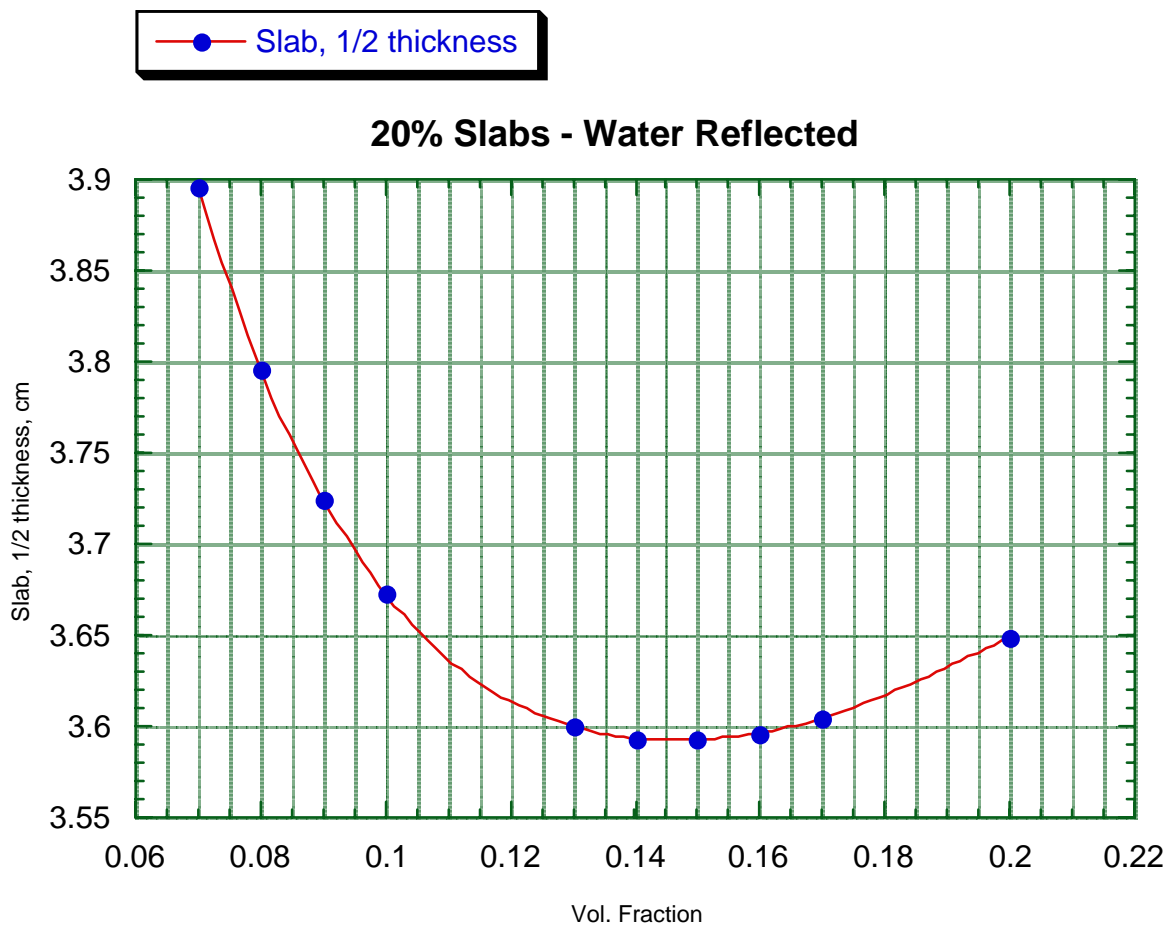

Fig. A.14. One-half thickness vs volume fraction for $20 \%$ enriched $\mathrm{UO}_{2}-\mathrm{H}_{2} \mathrm{O}$ slabs. 


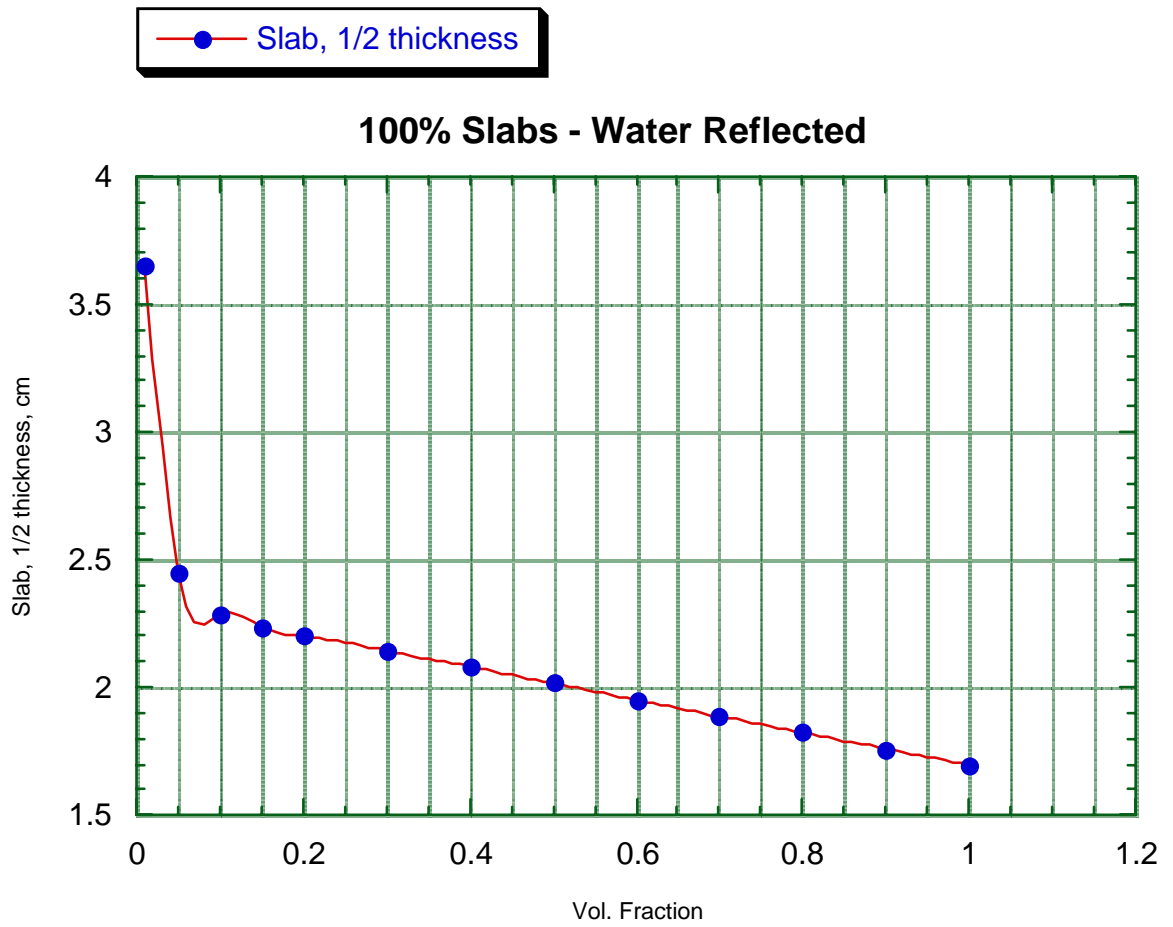

Fig. A.15. One-half thickness vs volume fraction for $100 \%$ enriched $\mathrm{UO}_{2}-\mathrm{H}_{2} \mathrm{O}$ slabs. 


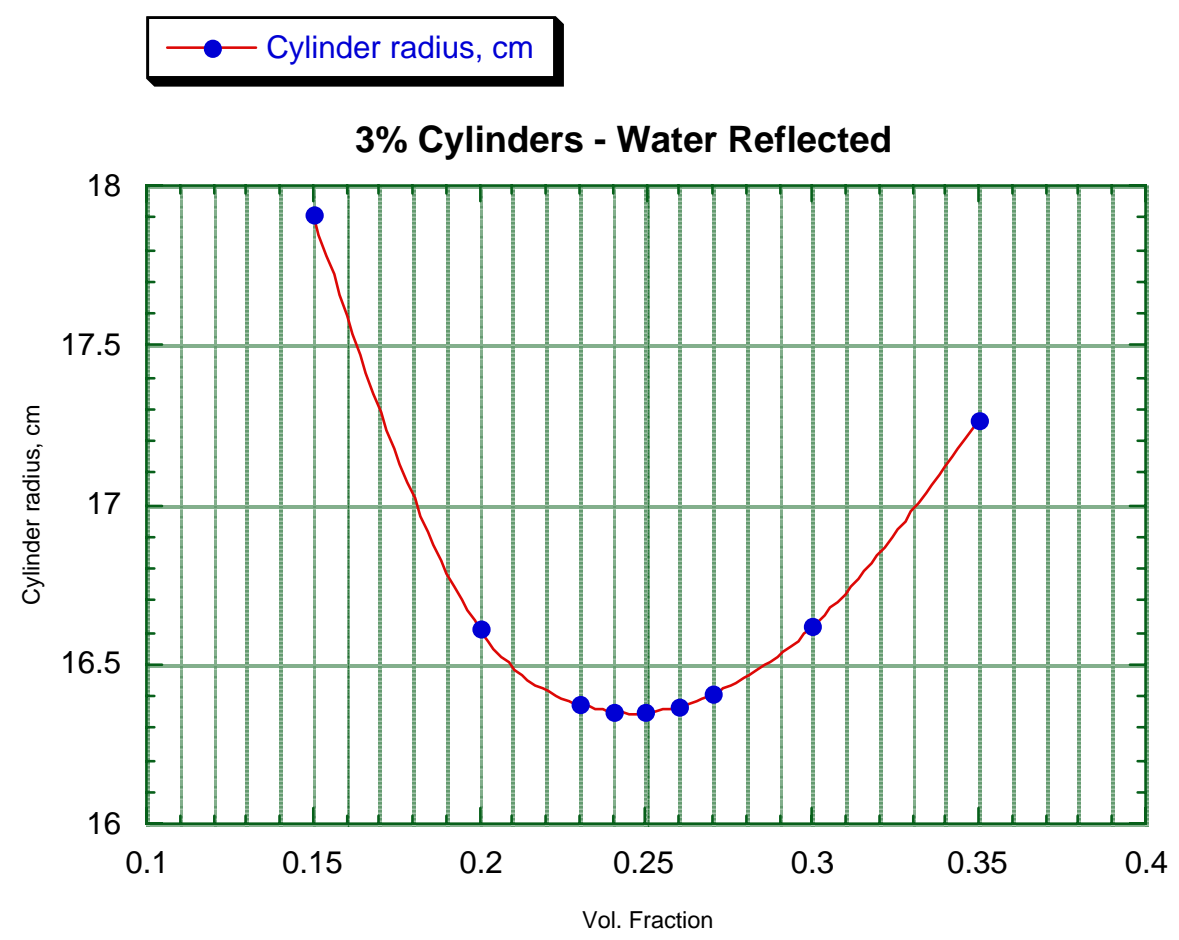

Fig. A.16. Radius vs volume fraction for $3 \%$ enriched $\mathrm{UO}_{2}-\mathrm{H}_{2} \mathrm{O}$ cylinders.

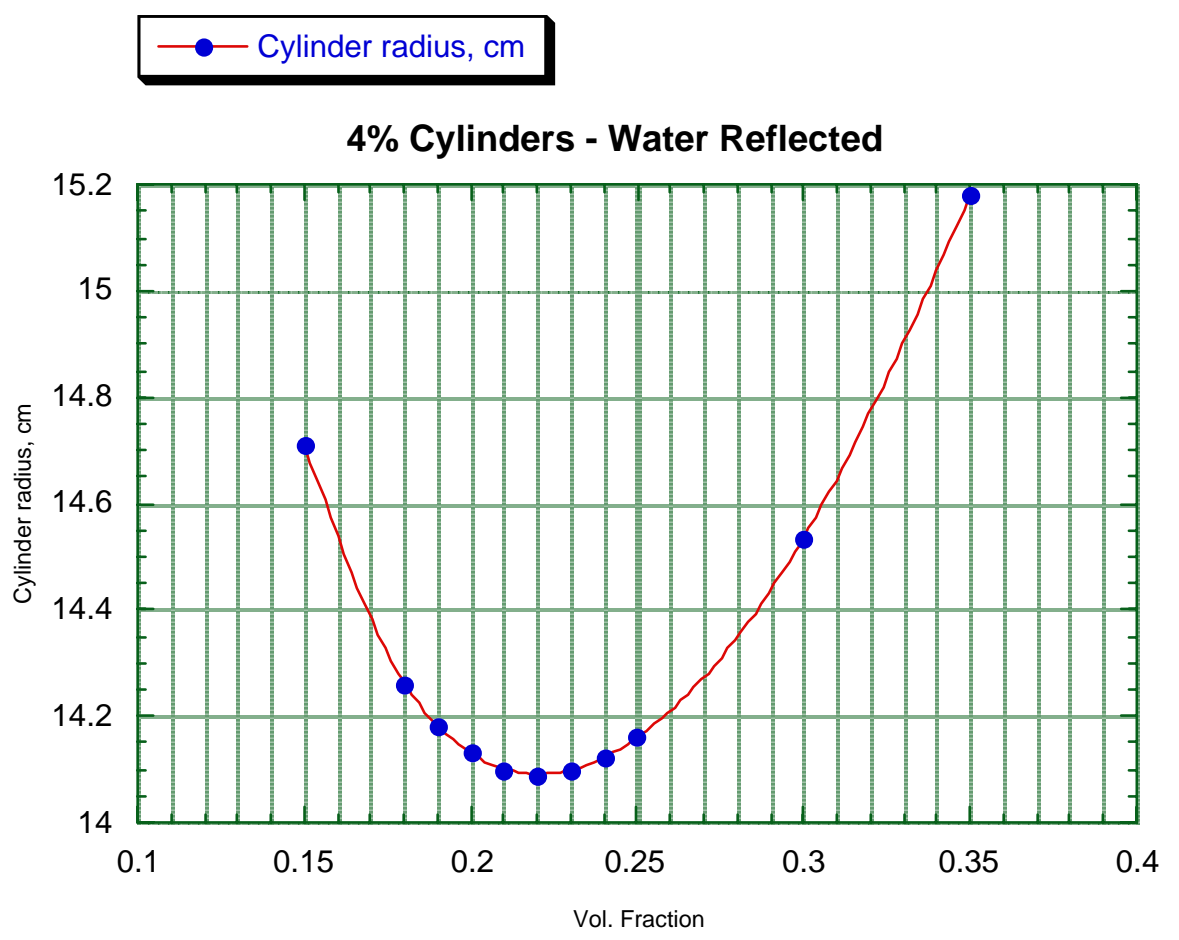

Fig. A.17. Radius vs volume fraction for $4 \%$ enriched $\mathrm{UO}_{2}-\mathrm{H}_{2} \mathrm{O}$ cylinders. 


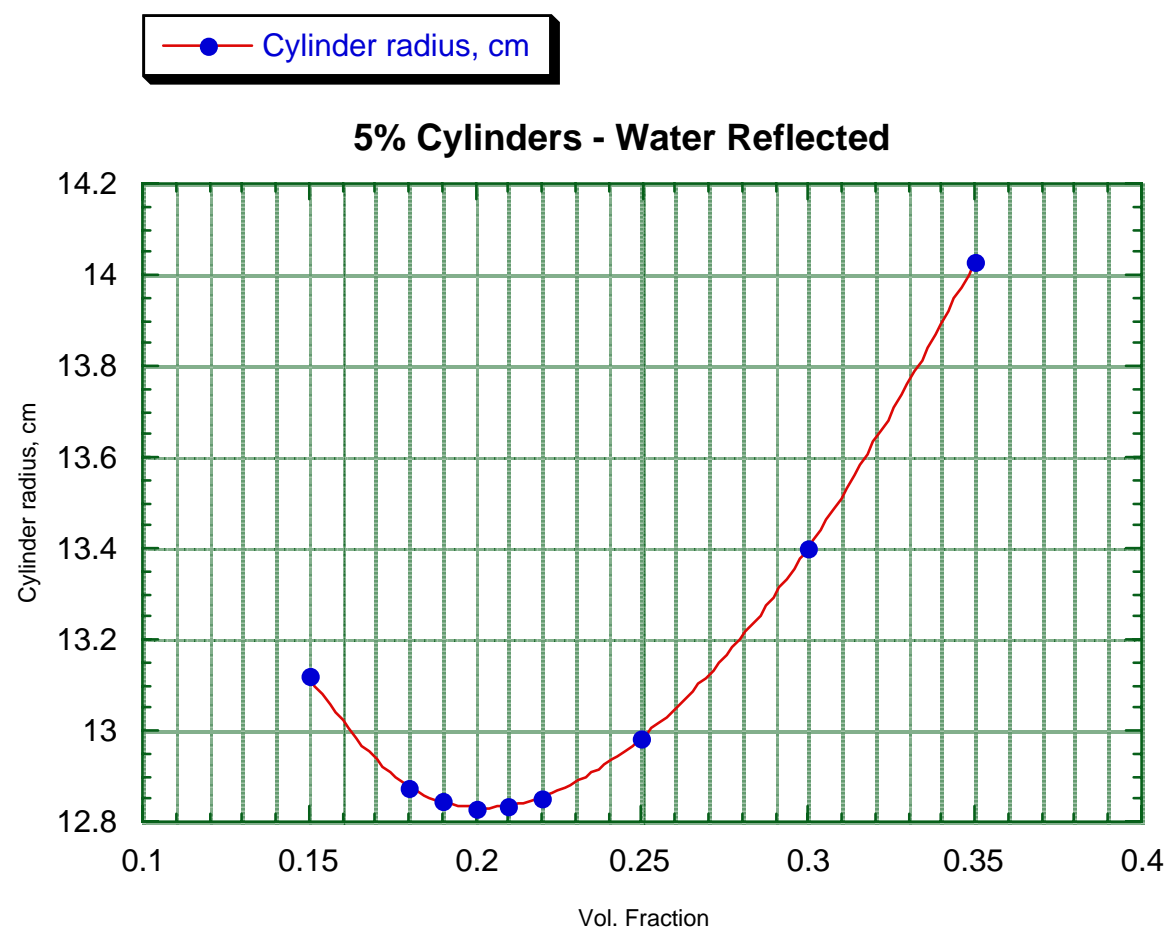

Fig. A.18. Radius vs volume fraction for $5 \%$ enriched $\mathrm{UO}_{2}-\mathrm{H}_{2} \mathrm{O}$ cylinders.

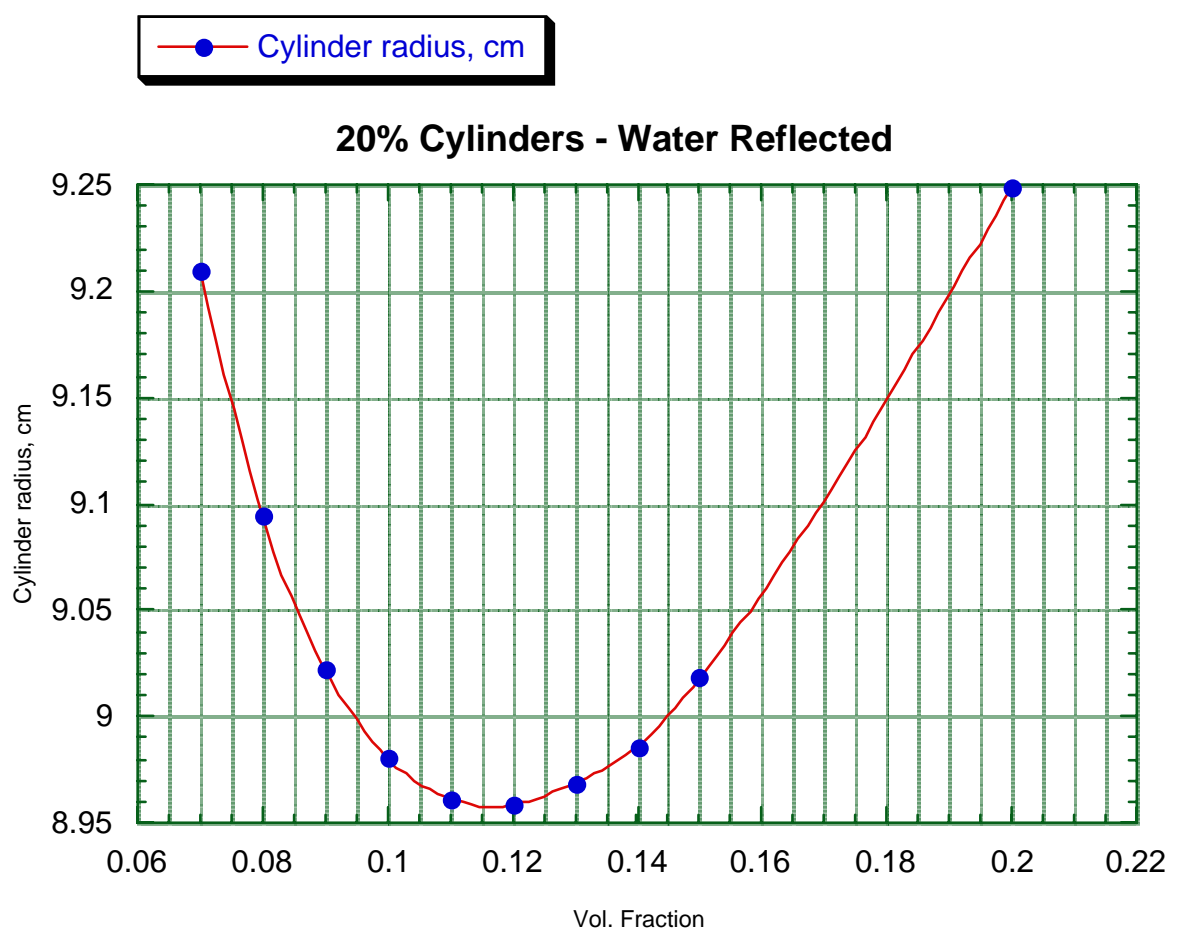

Fig. A.19. Radius vs volume fraction for $20 \%$ enriched $\mathrm{UO}_{2}-\mathrm{H}_{2} \mathrm{O}$ cylinders. 


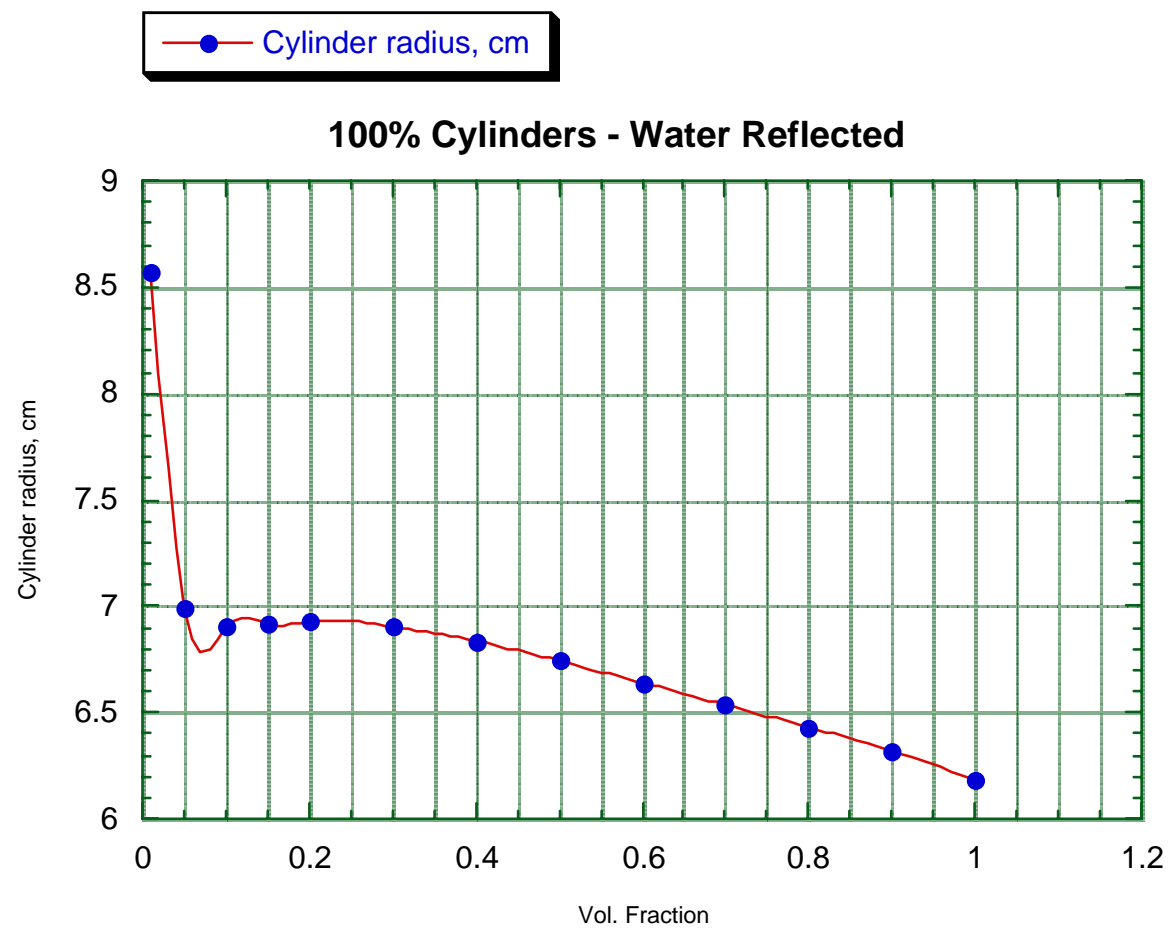

Fig. A.20. Radius vs volume fraction for $100 \%$ enriched $\mathrm{UO}_{2}-\mathrm{H}_{2} \mathrm{O}$ cylinders. 


\section{APPENDIX B}

GRAPHS OF UNH- $\mathrm{H}_{2} \mathrm{O}$, WATER REFLECTED $(30 \mathrm{~cm})$ : CRITICAL PARAMETERS vs URANIUM DENSITY 



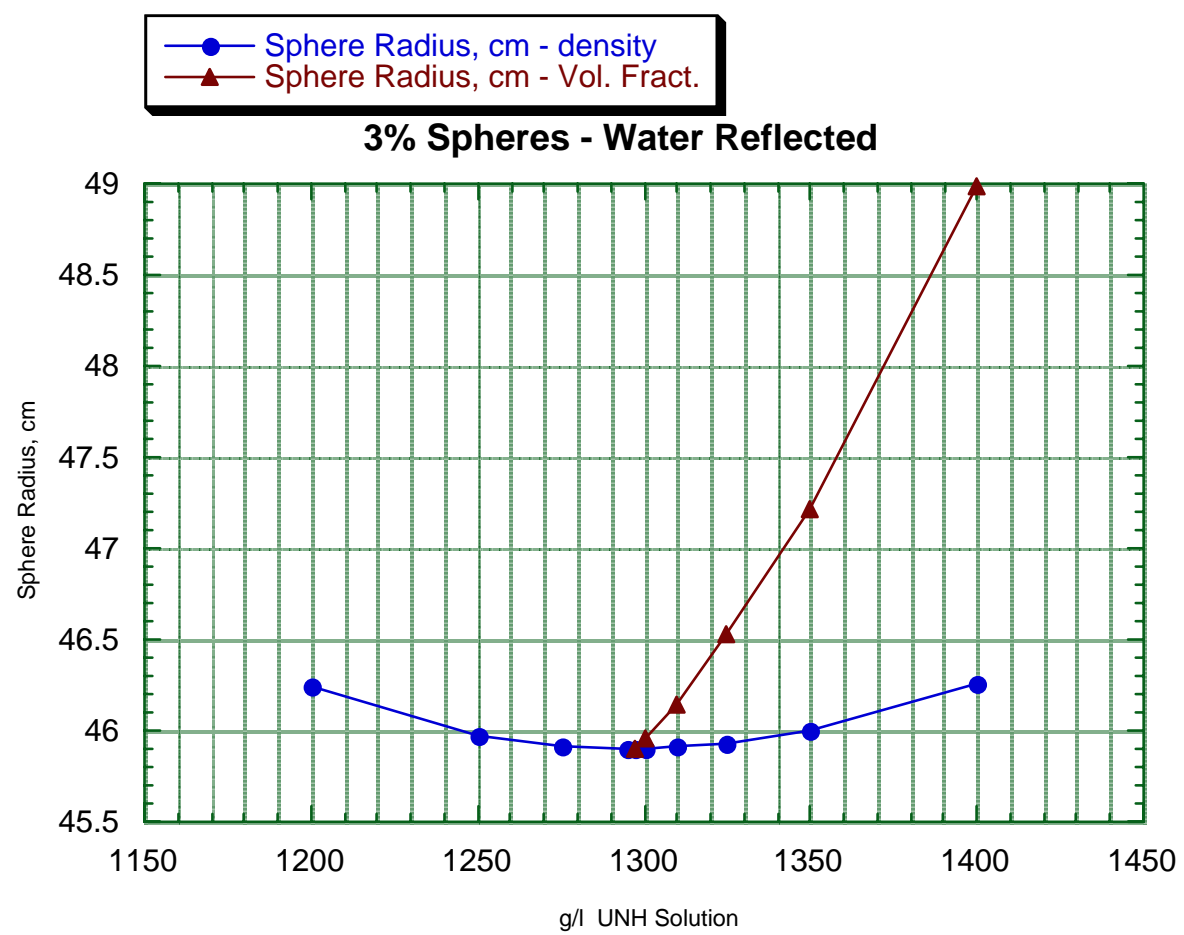

Fig. B.1. Radius vs density and volume fraction for $3 \%$ enriched $\mathrm{UNH}-\mathrm{H}_{2} \mathrm{O}$ spheres.

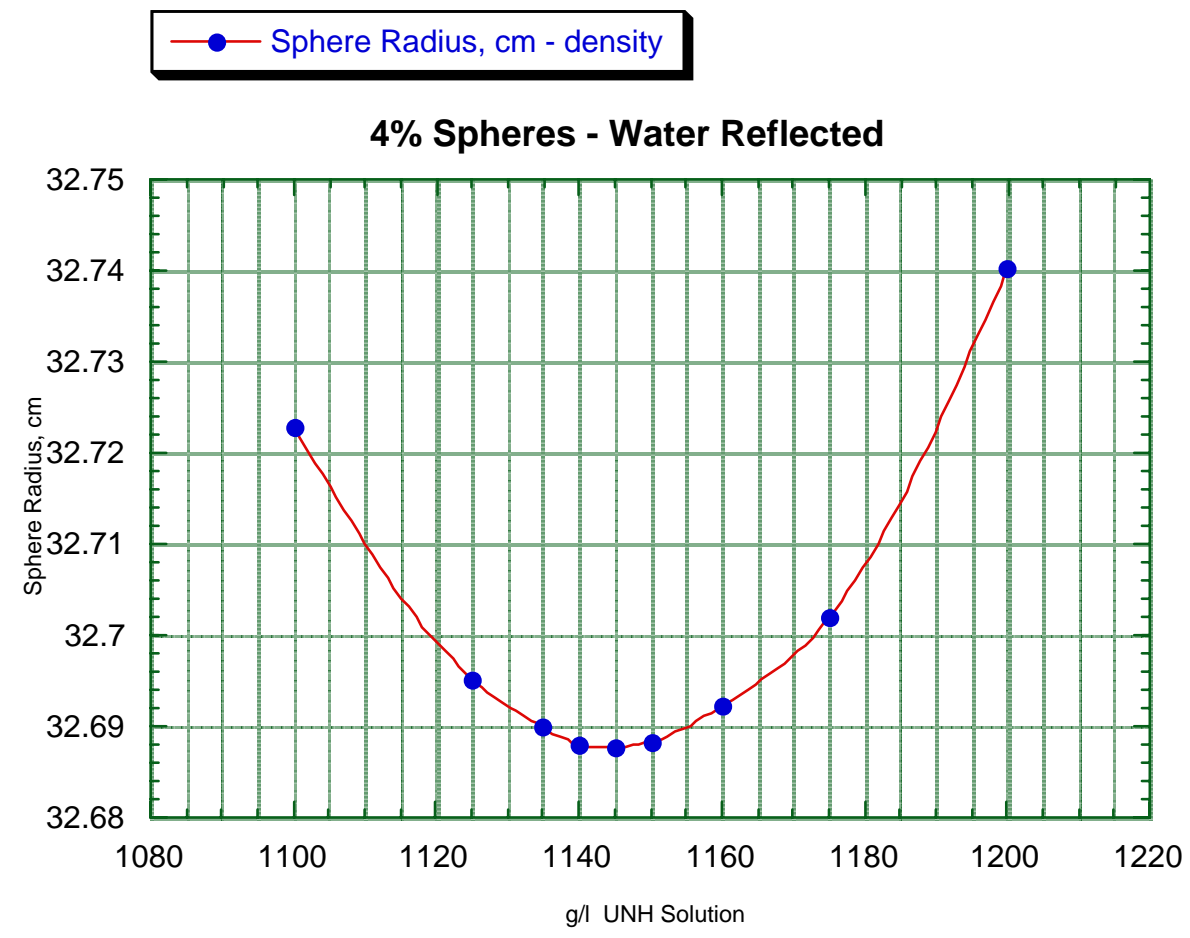

Fig. B.2. Radius vs density for $4 \%$ enriched $\mathrm{UNH}-\mathrm{H}_{2} \mathrm{O}$ spheres. 


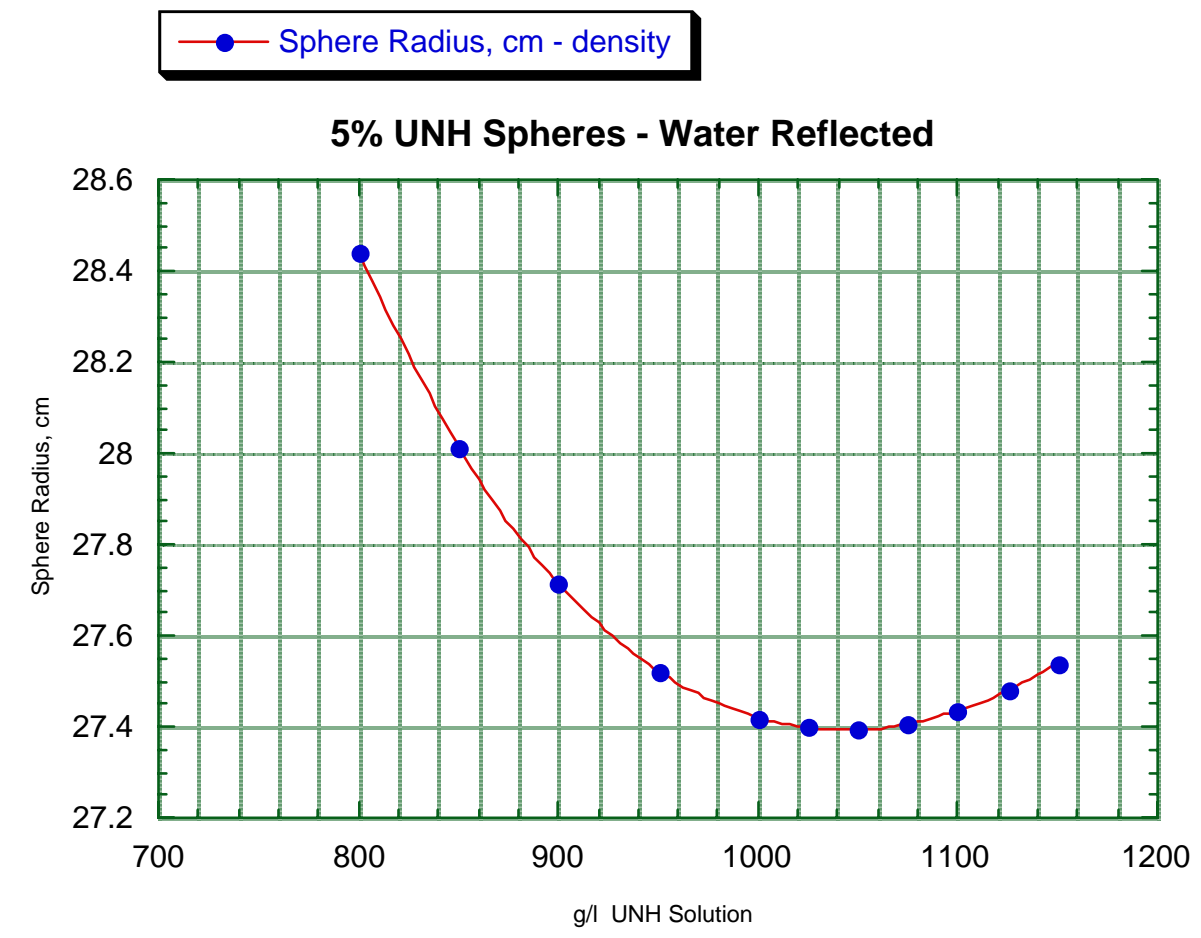

Fig. B.3. Radius vs density for $5 \%$ enriched $\mathrm{UNH}-\mathrm{H}_{2} \mathrm{O}$ spheres.

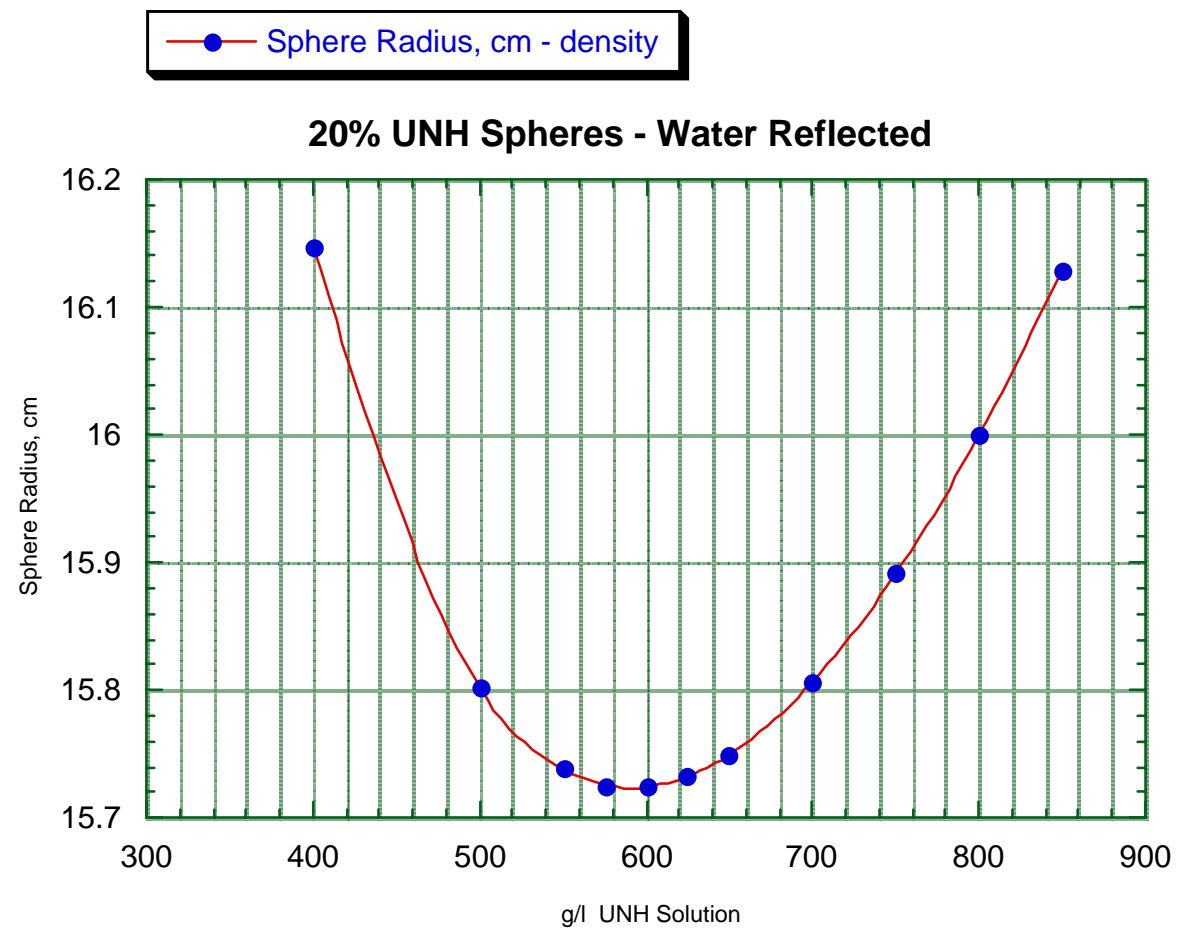

Fig. B.4. Radius vs density for $20 \%$ enriched $\mathrm{UNH}-\mathrm{H}_{2} \mathrm{O}$ spheres. 


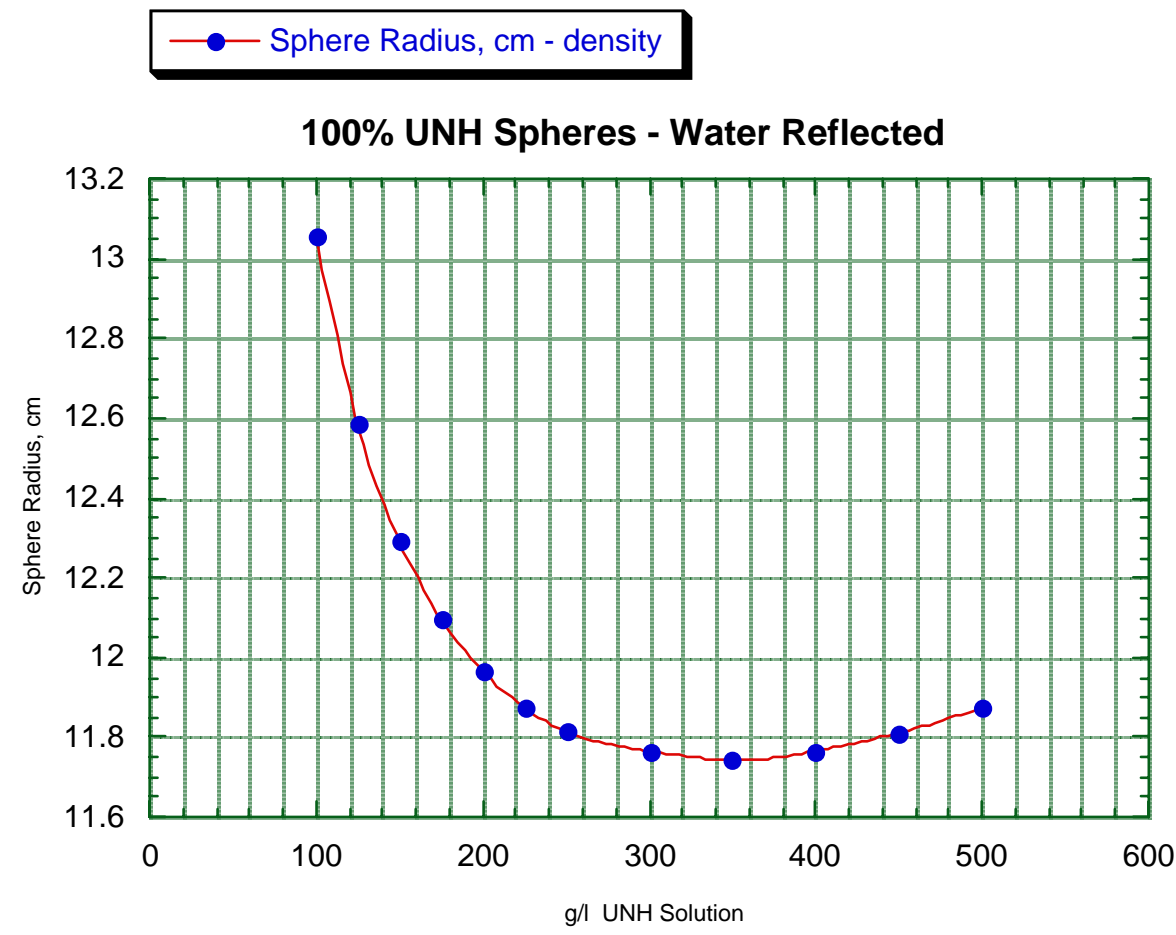

Fig. B.5. Radius vs density for $100 \%$ enriched $\mathrm{UNH}-\mathrm{H}_{2} \mathrm{O}$ spheres. 


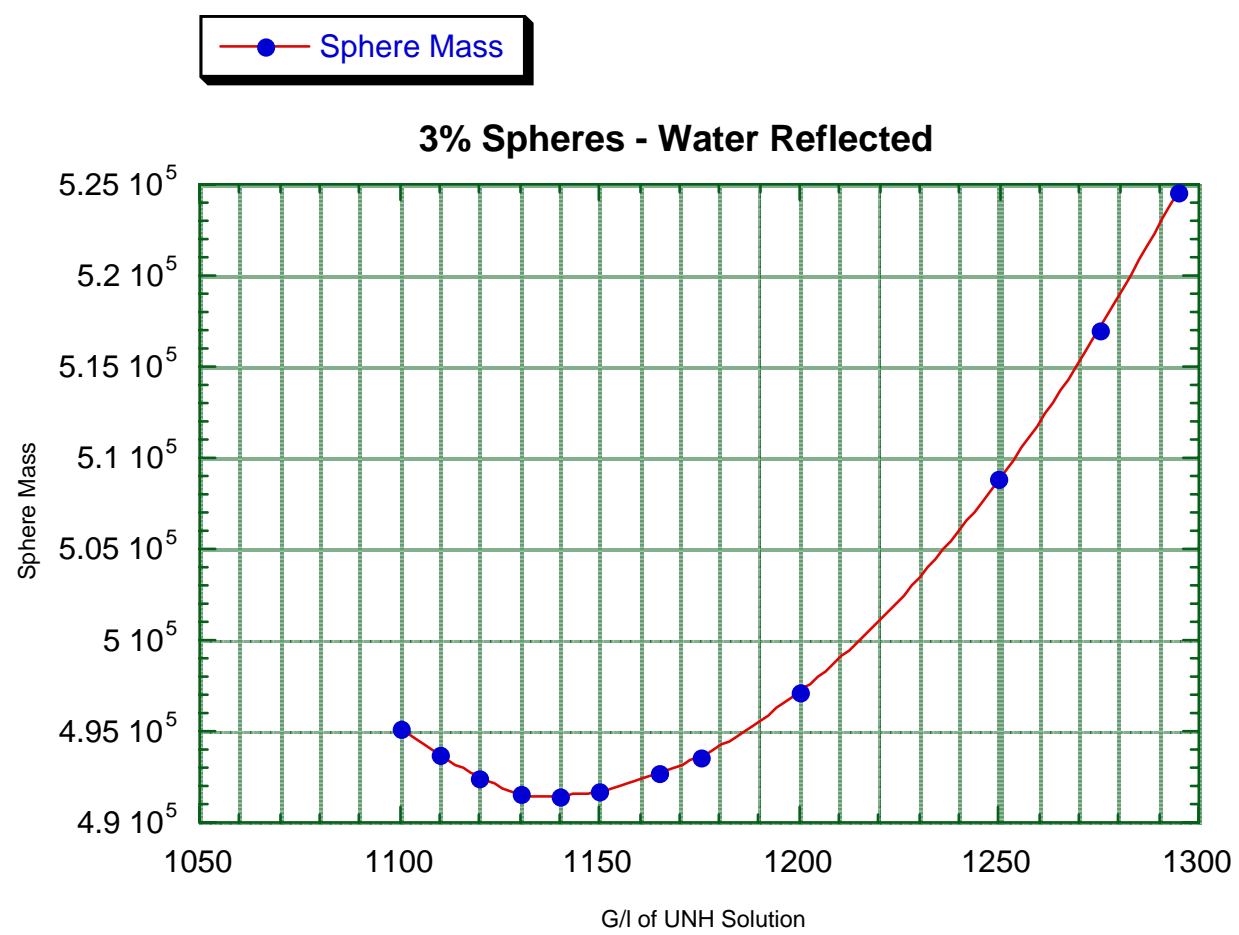

Fig. B.6. Mass vs density for $3 \%$ enriched $\mathrm{UNH}-\mathrm{H}_{2} \mathrm{O}$ spheres.

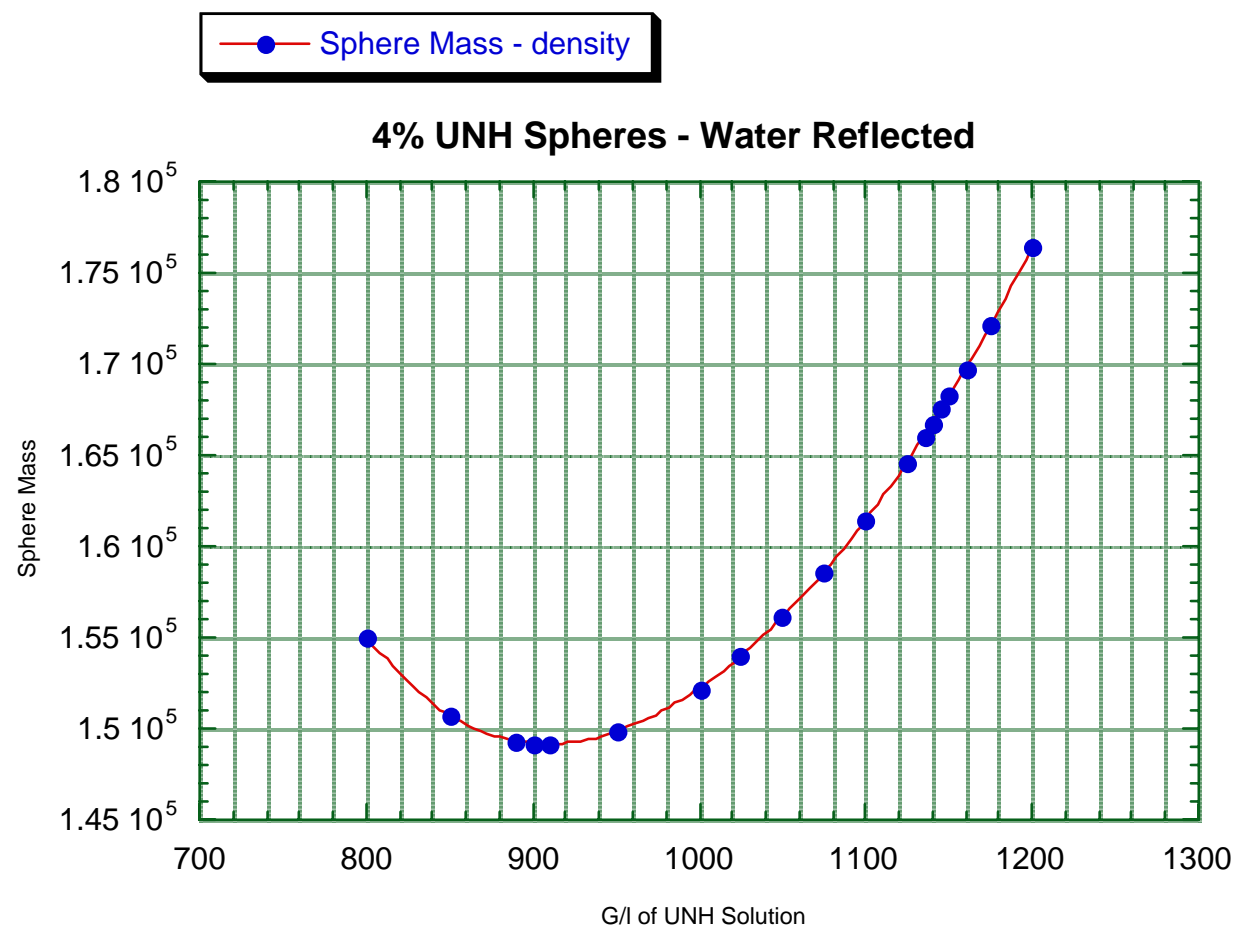

Fig. B.7. Mass vs density for $4 \%$ enriched $\mathrm{UNH}-\mathrm{H}_{2} \mathrm{O}$ spheres. 


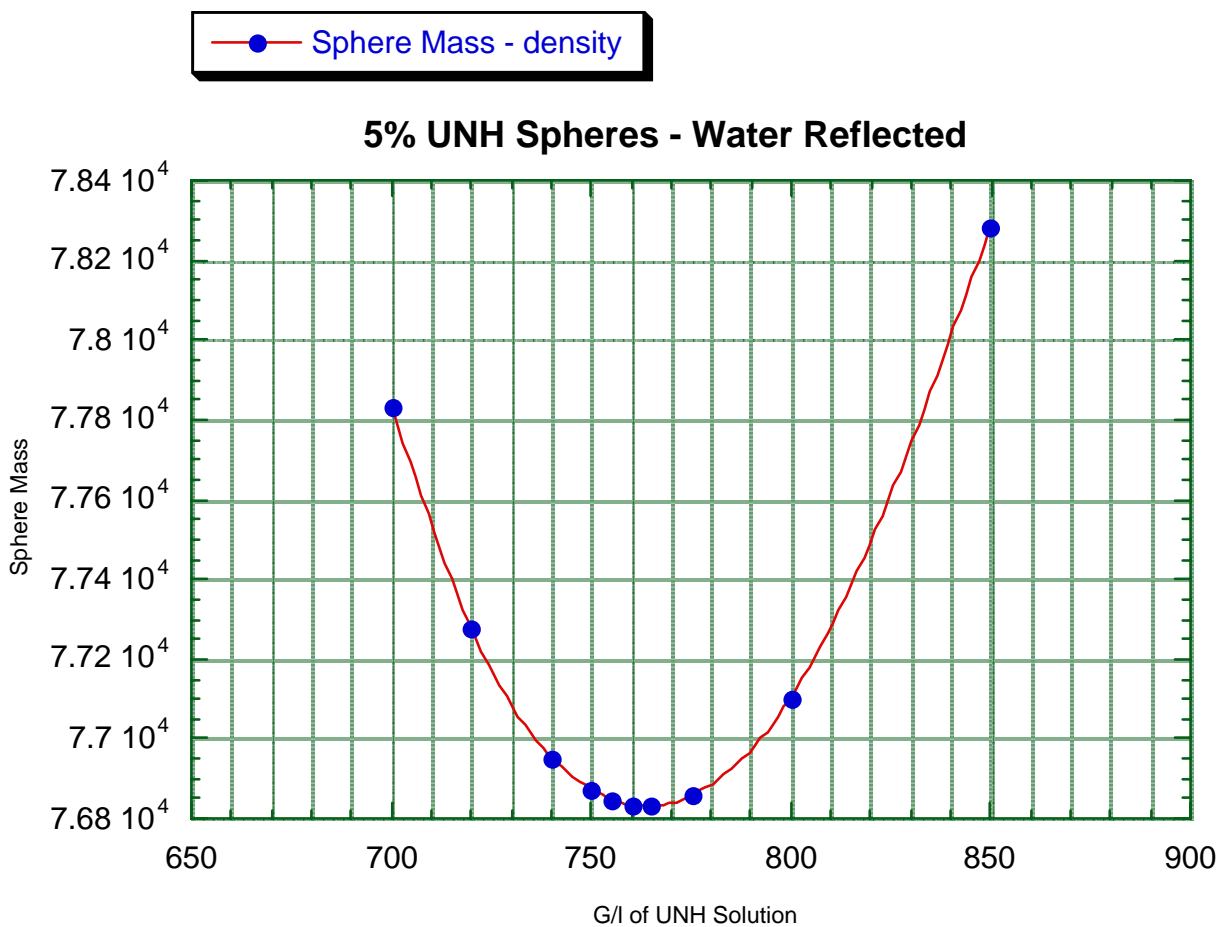

Fig. B.8. Mass vs density for $5 \%$ enriched $\mathrm{UNH}-\mathrm{H}_{2} \mathrm{O}$ spheres.

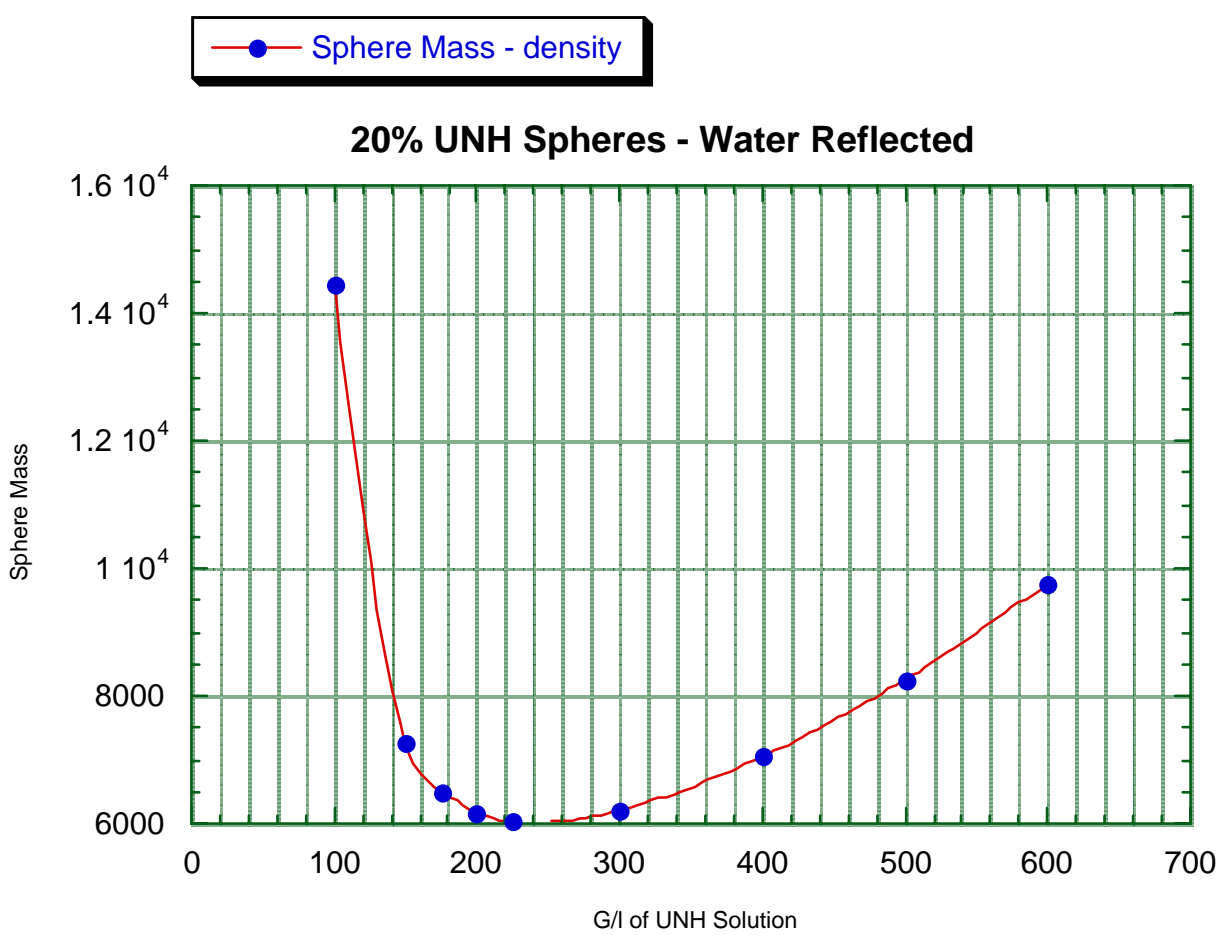

Fig. B.9. Mass vs density for $20 \%$ enriched $\mathrm{UNH}-\mathrm{H}_{2} \mathrm{O}$ spheres. 


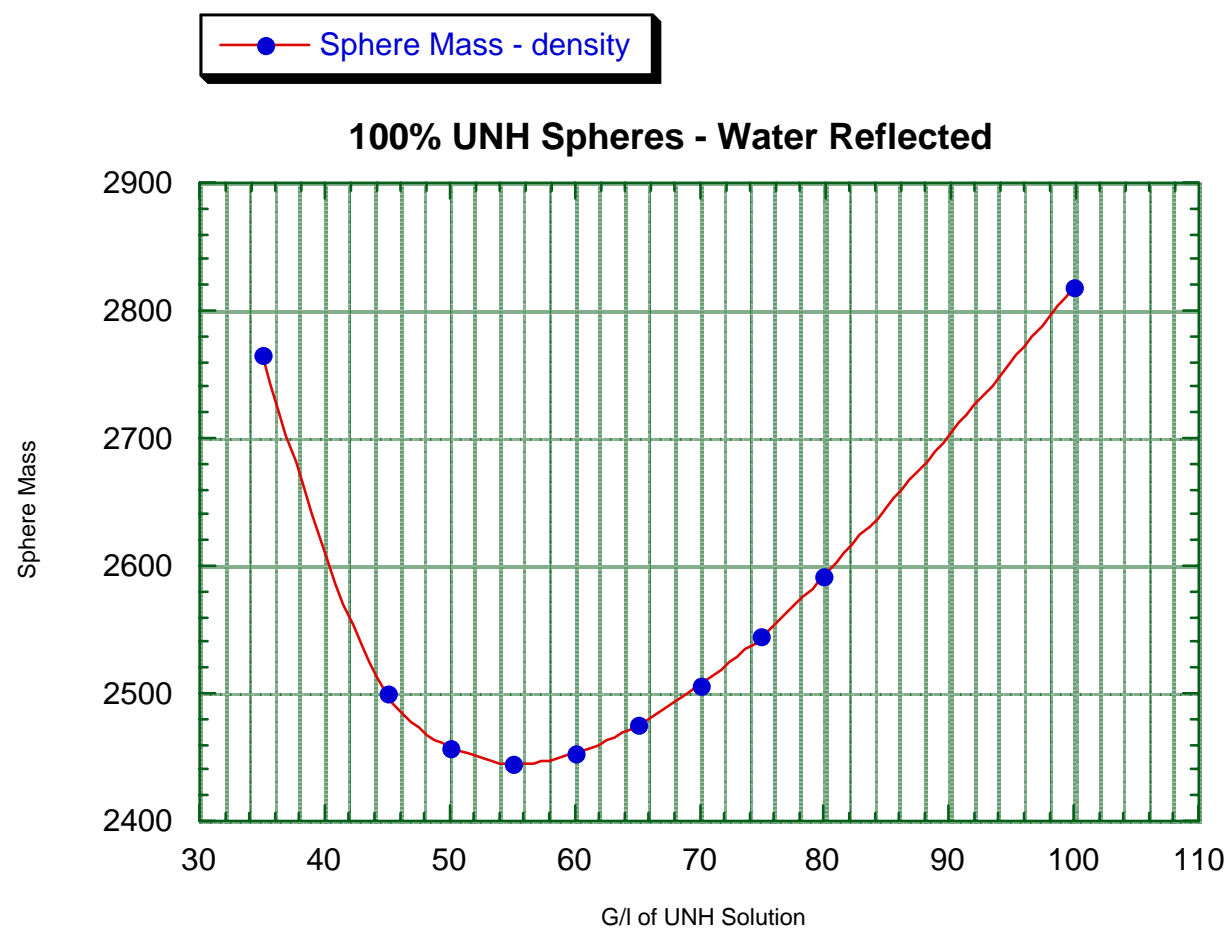

Fig. B.10. Mass vs density for $100 \%$ enriched $\mathrm{UNH}-\mathrm{H}_{2} \mathrm{O}$ spheres. 


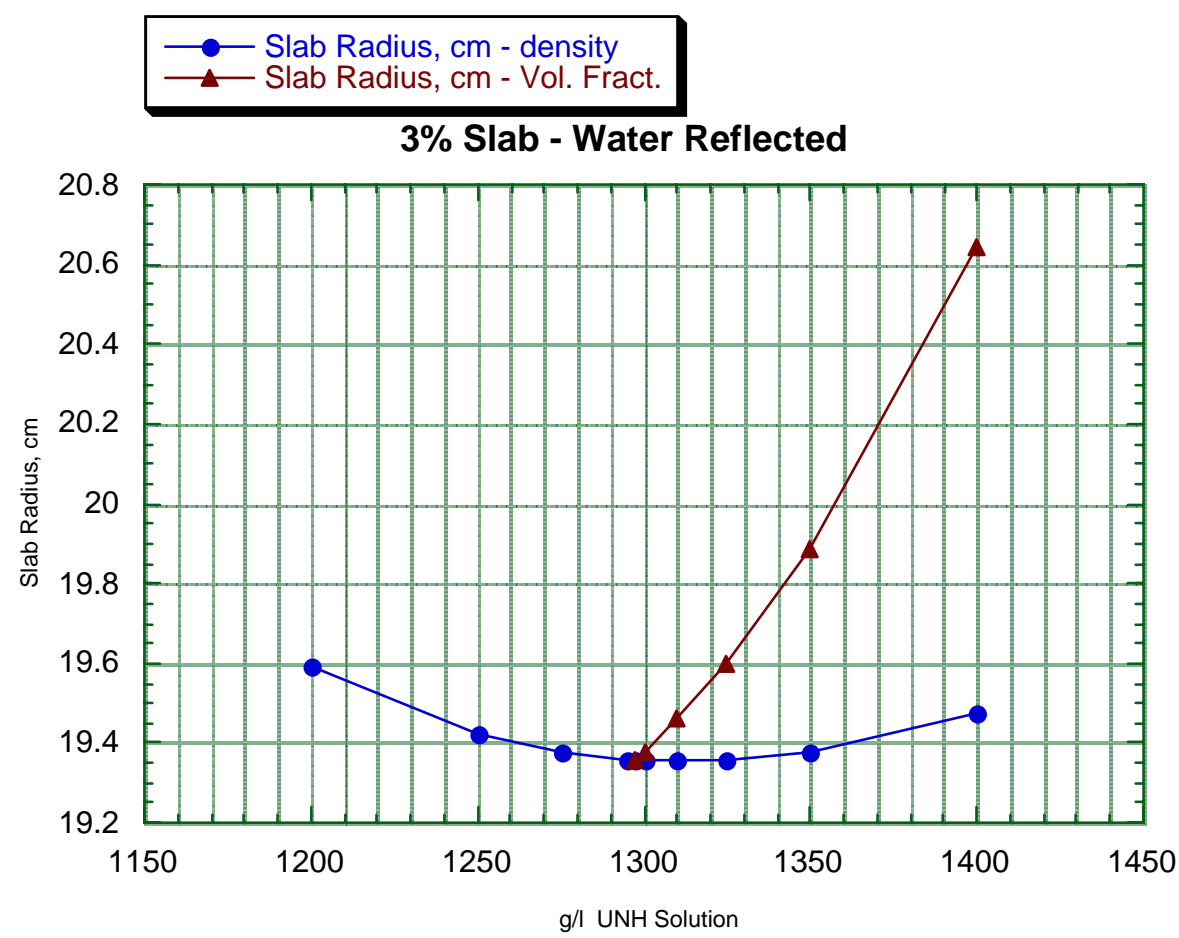

Fig. B.11. Radius vs density and volume fraction for $3 \%$ enriched $\mathrm{UNH}-\mathrm{H}_{2} \mathrm{O}$ slabs.

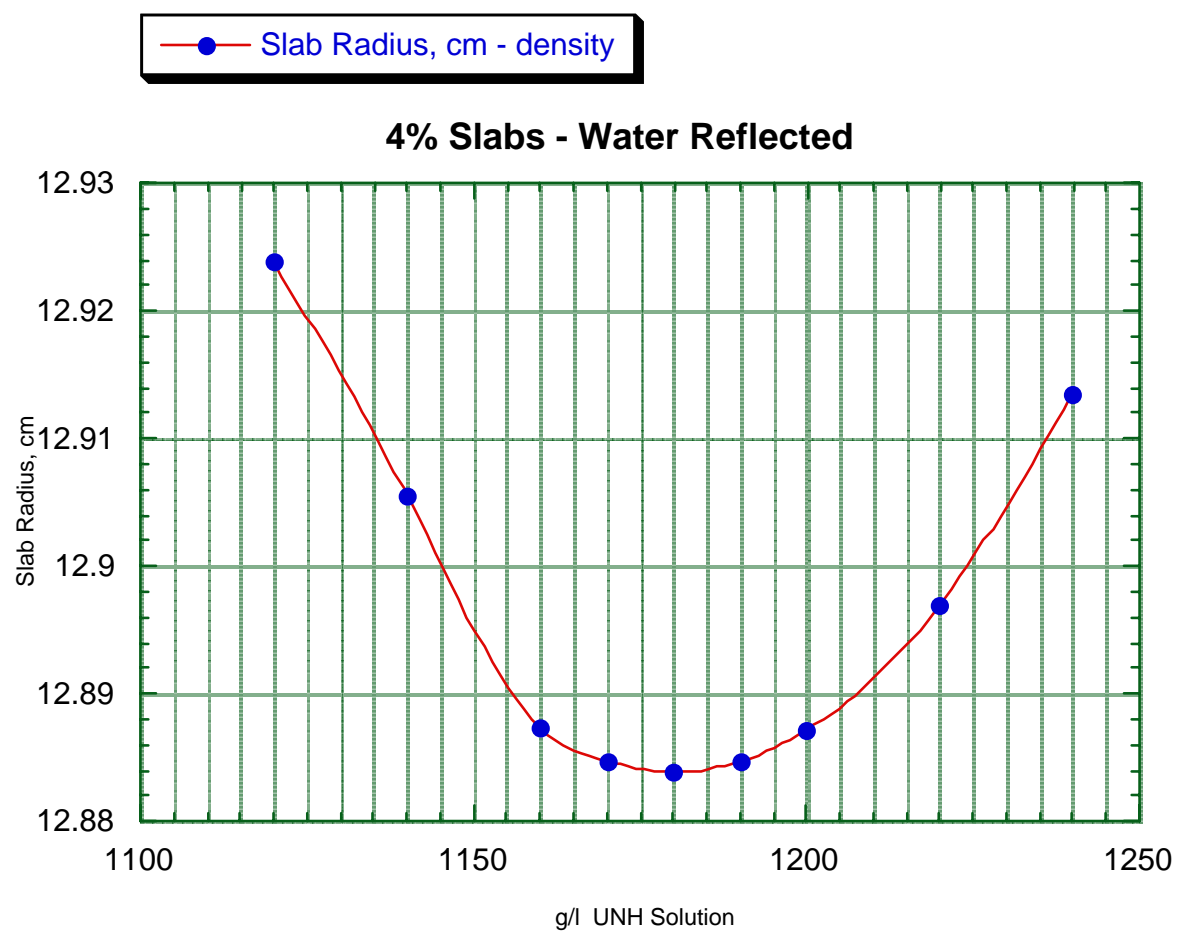

Fig. B.12. Radius vs density for $4 \%$ enriched $\mathrm{UNH}-\mathrm{H}_{2} \mathrm{O}$ slabs. 


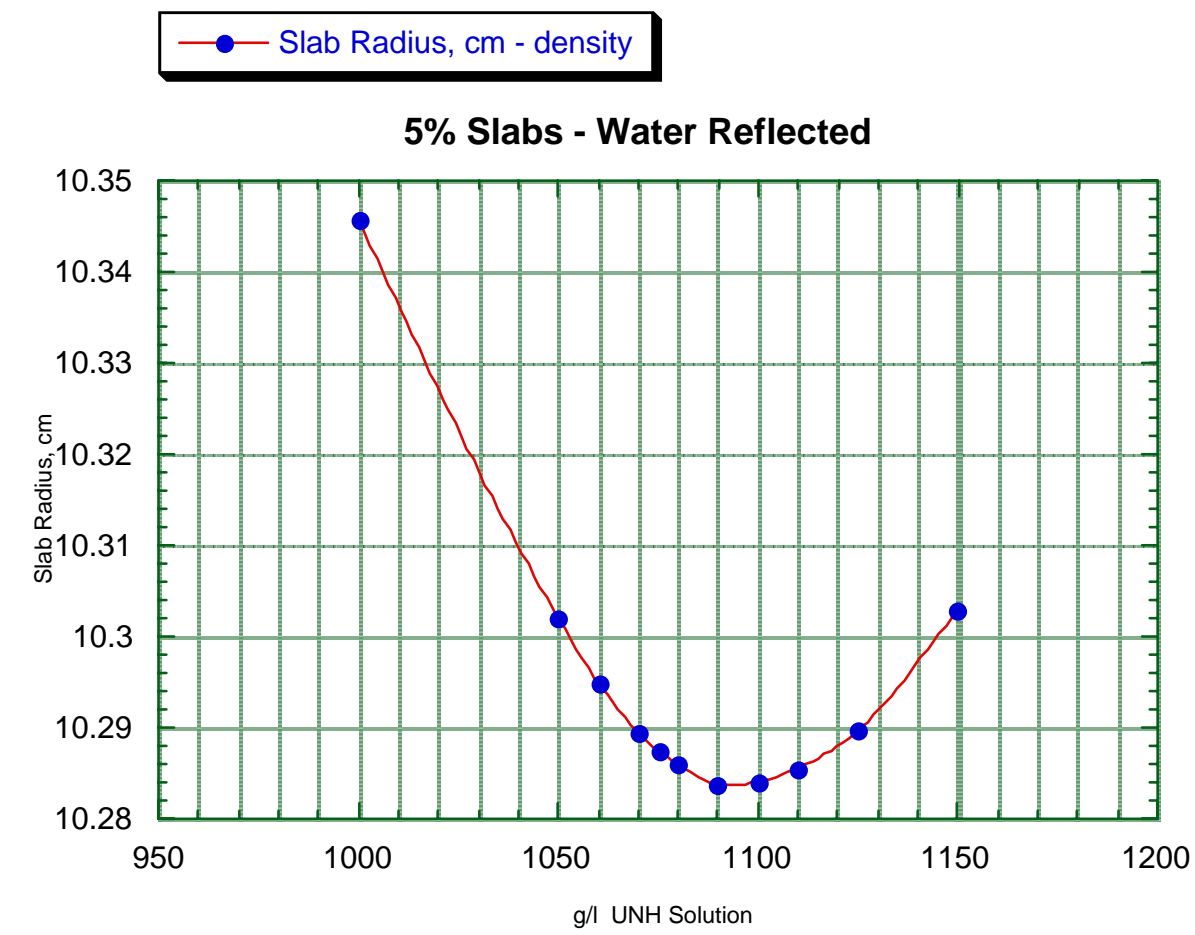

Fig. B.13. Radius vs density for $5 \%$ enriched $\mathrm{UNH}-\mathrm{H}_{2} \mathrm{O}$ slabs.

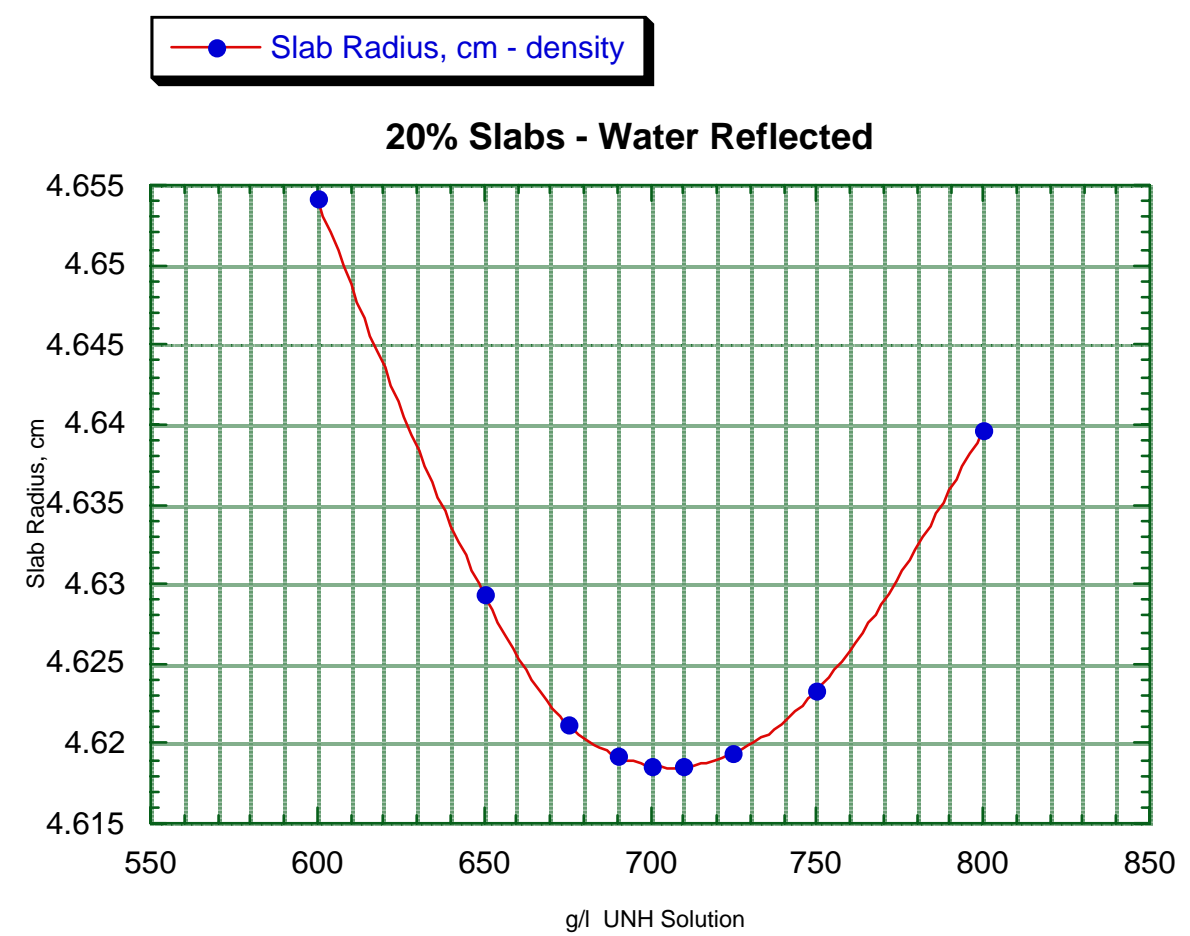

Fig. B.14. Radius vs density for $20 \%$ enriched $\mathrm{UNH}-\mathrm{H}_{2} \mathrm{O}$ slabs. 


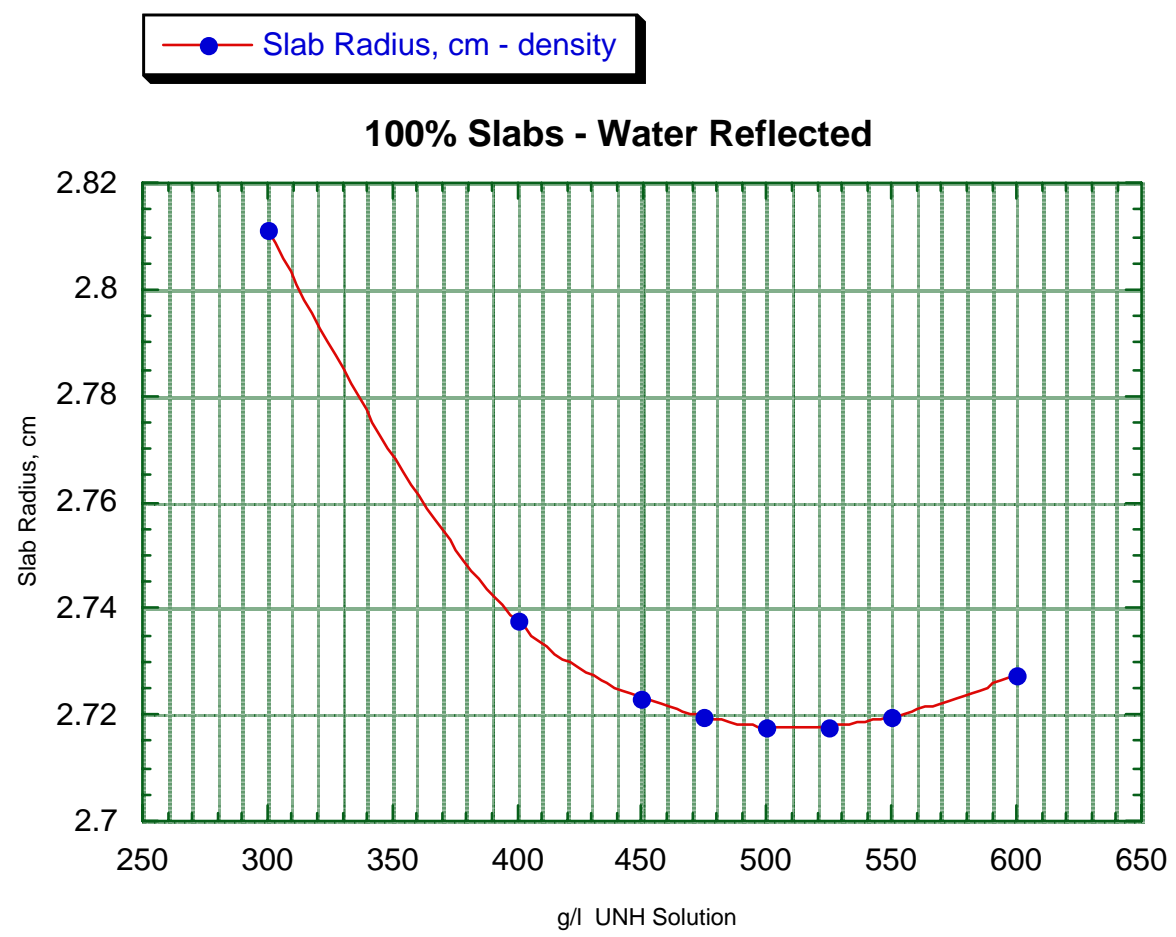

Fig. B.15. Radius vs density for $100 \%$ enriched $\mathrm{UNH}-\mathrm{H}_{2} \mathrm{O}$ slabs. 


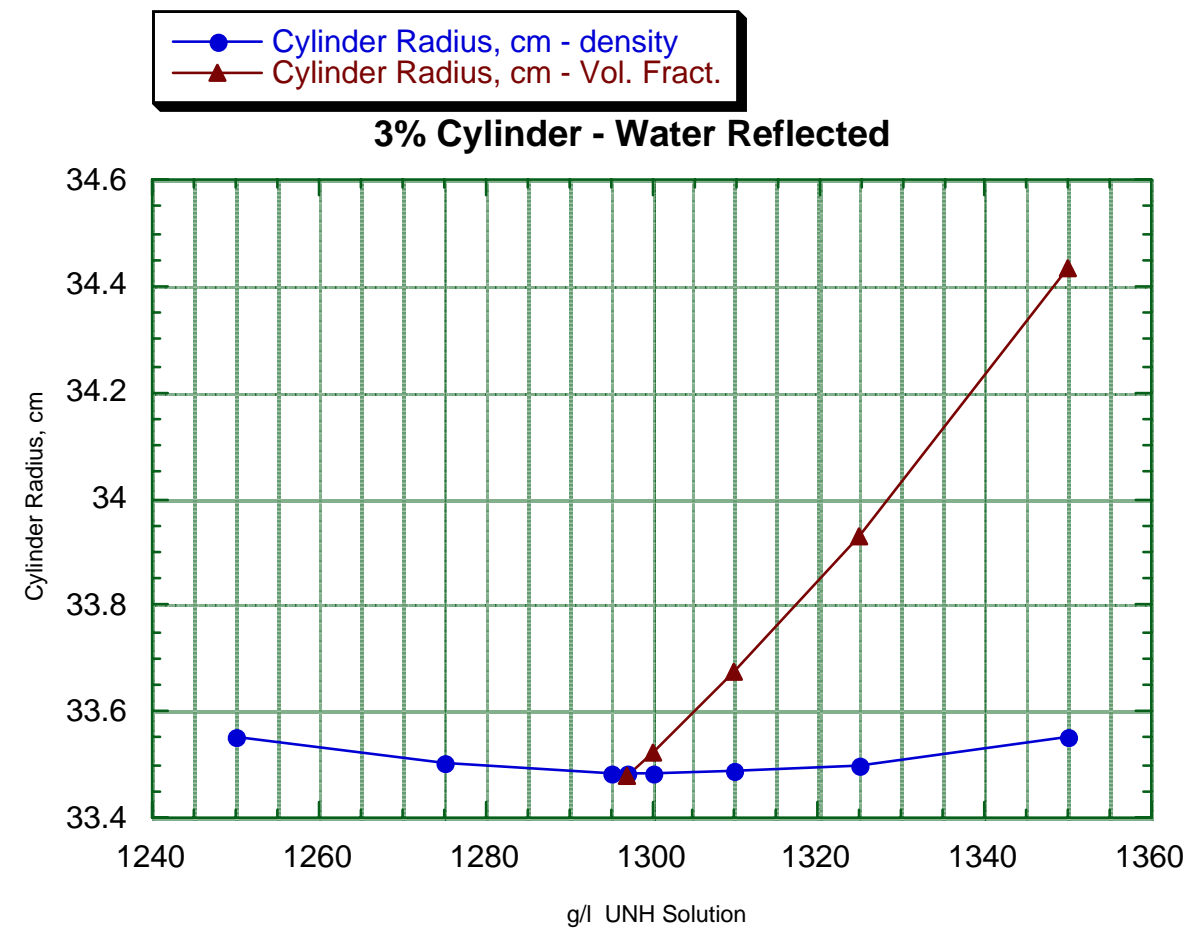

Fig. B.16. Radius vs density and volume fraction for $3 \%$ enriched $\mathrm{UNH}-\mathrm{H}_{2} \mathrm{O}$ cylinders.

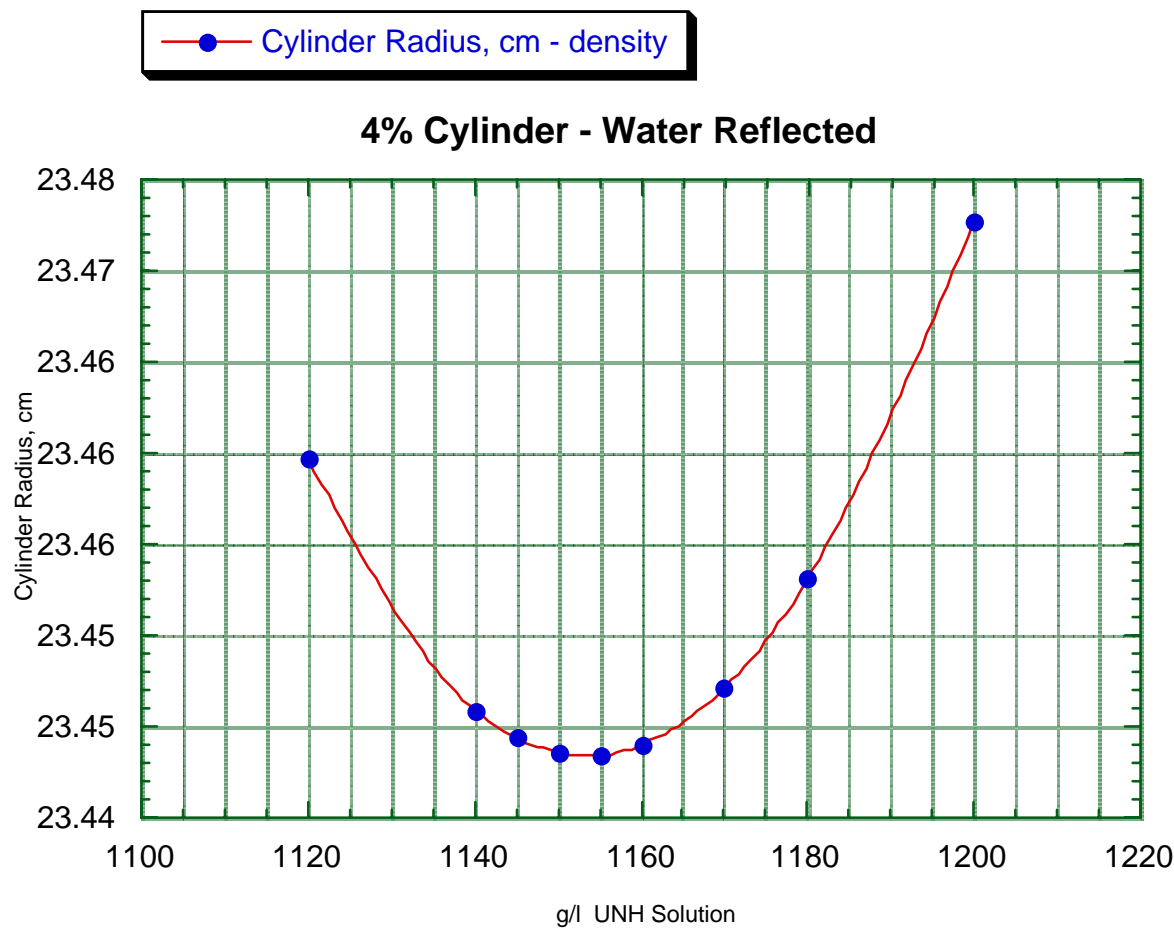

Fig. B.17. Radius vs density for $4 \%$ enriched $\mathrm{UNH}-\mathrm{H}_{2} \mathrm{O}$ cylinders. 


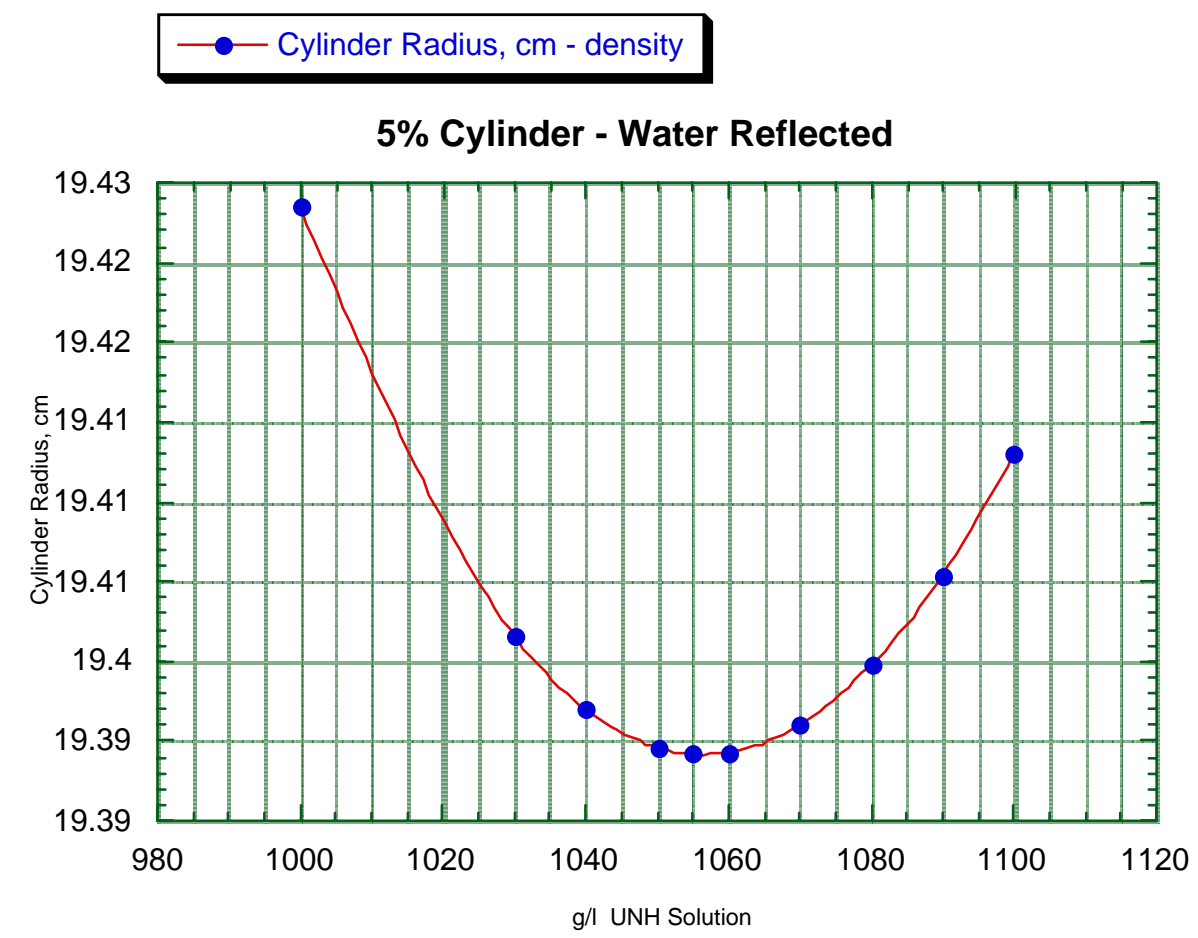

Fig. B.18. Radius vs density for $5 \%$ enriched $\mathrm{UNH}-\mathrm{H}_{2} \mathrm{O}$ cylinders.

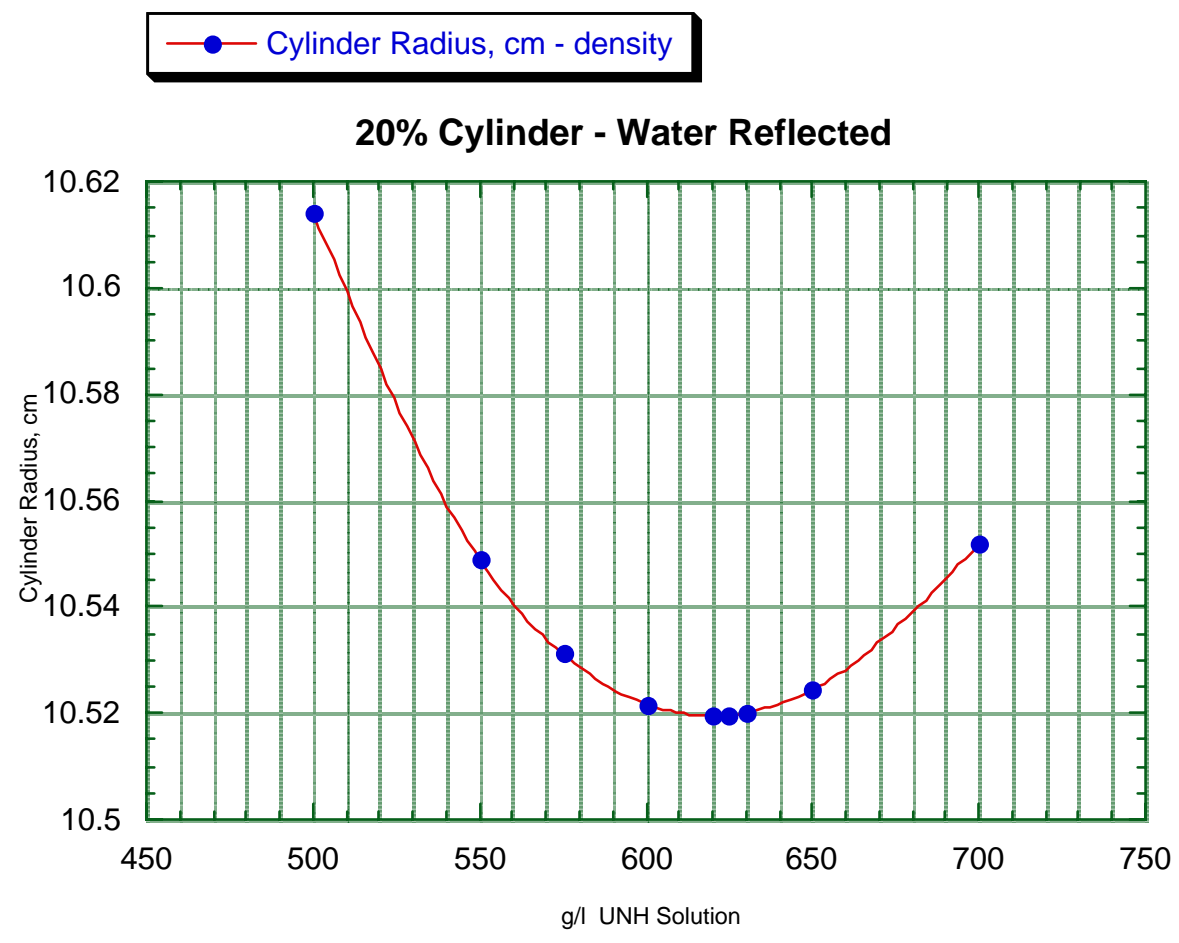

Fig. B.19. Radius vs density for $20 \%$ enriched $\mathrm{UNH}-\mathrm{H}_{2} \mathrm{O}$ cylinders. 


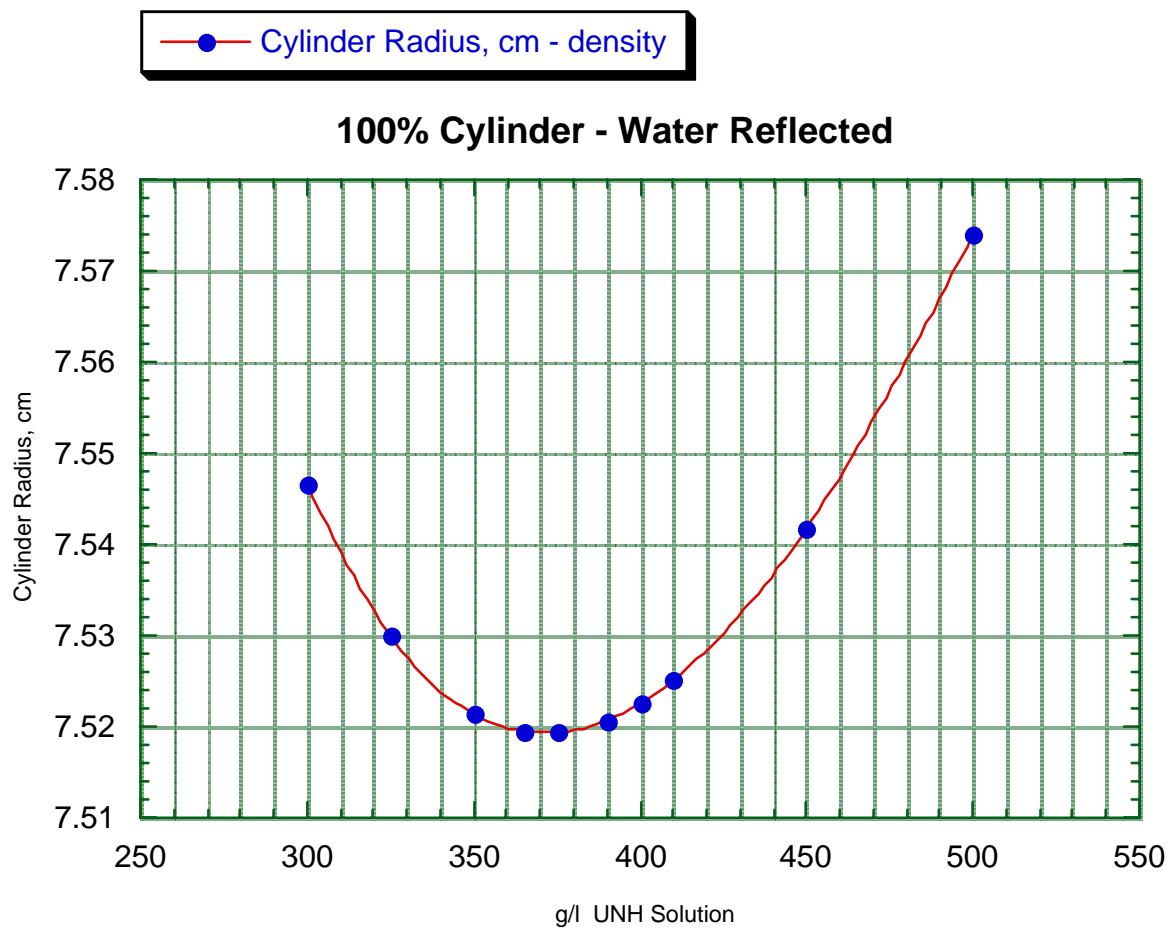

Fig. B.20. Radius vs density for $100 \%$ enriched $\mathrm{UNH}-\mathrm{H}_{2} \mathrm{O}$ cylinders. 
APPENDIX C

GRAPHS OF $\mathrm{PuO}_{2}-\mathrm{H}_{2} \mathrm{O}$, WATER REFLECTED $(30 \mathrm{~cm})$ : CRITICAL PARAMETERS vS FUEL VOLUME FRACTIONS 



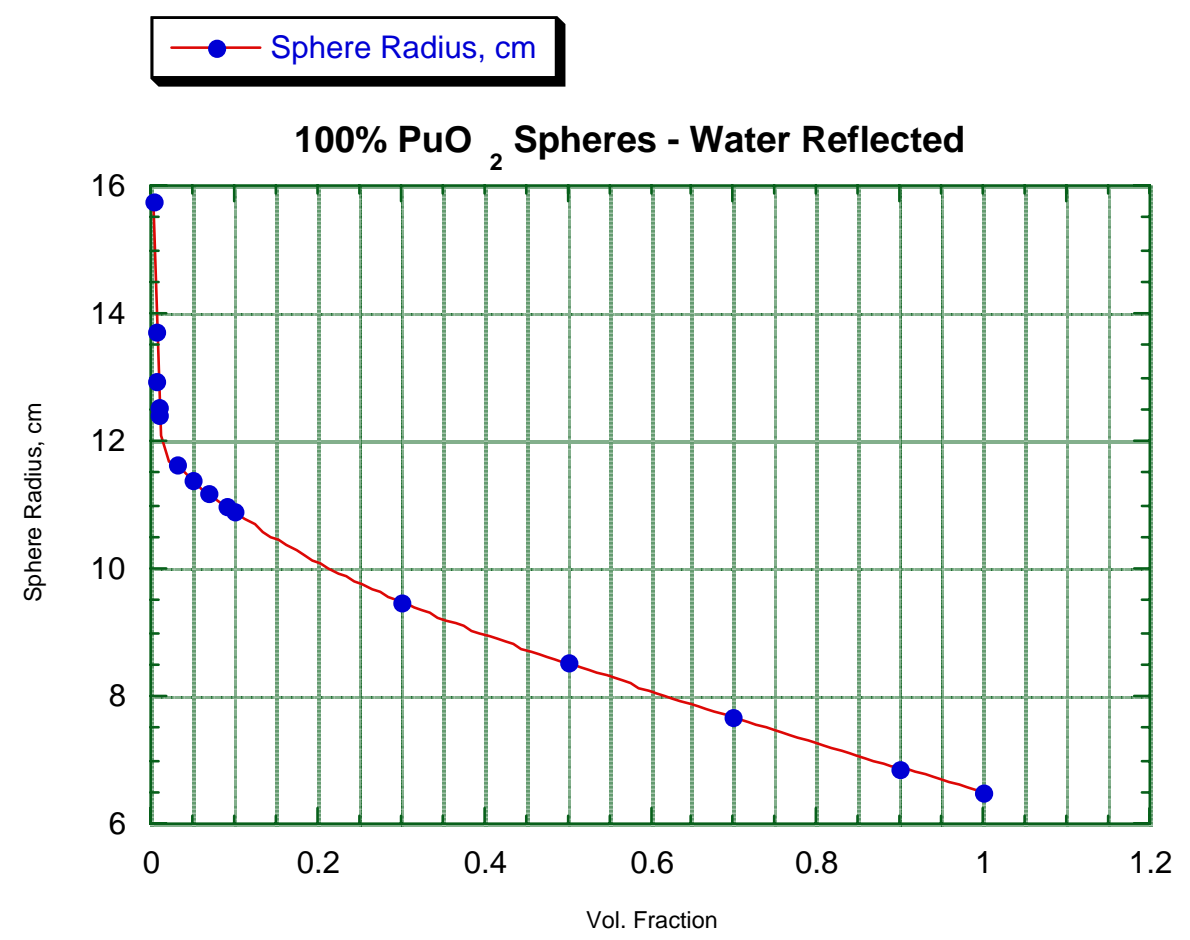

Fig. C.1. Radius vs volume fraction for $100 \%$ enriched $\mathrm{PuO}_{2}-\mathrm{H}_{2} \mathrm{O}$ spheres.

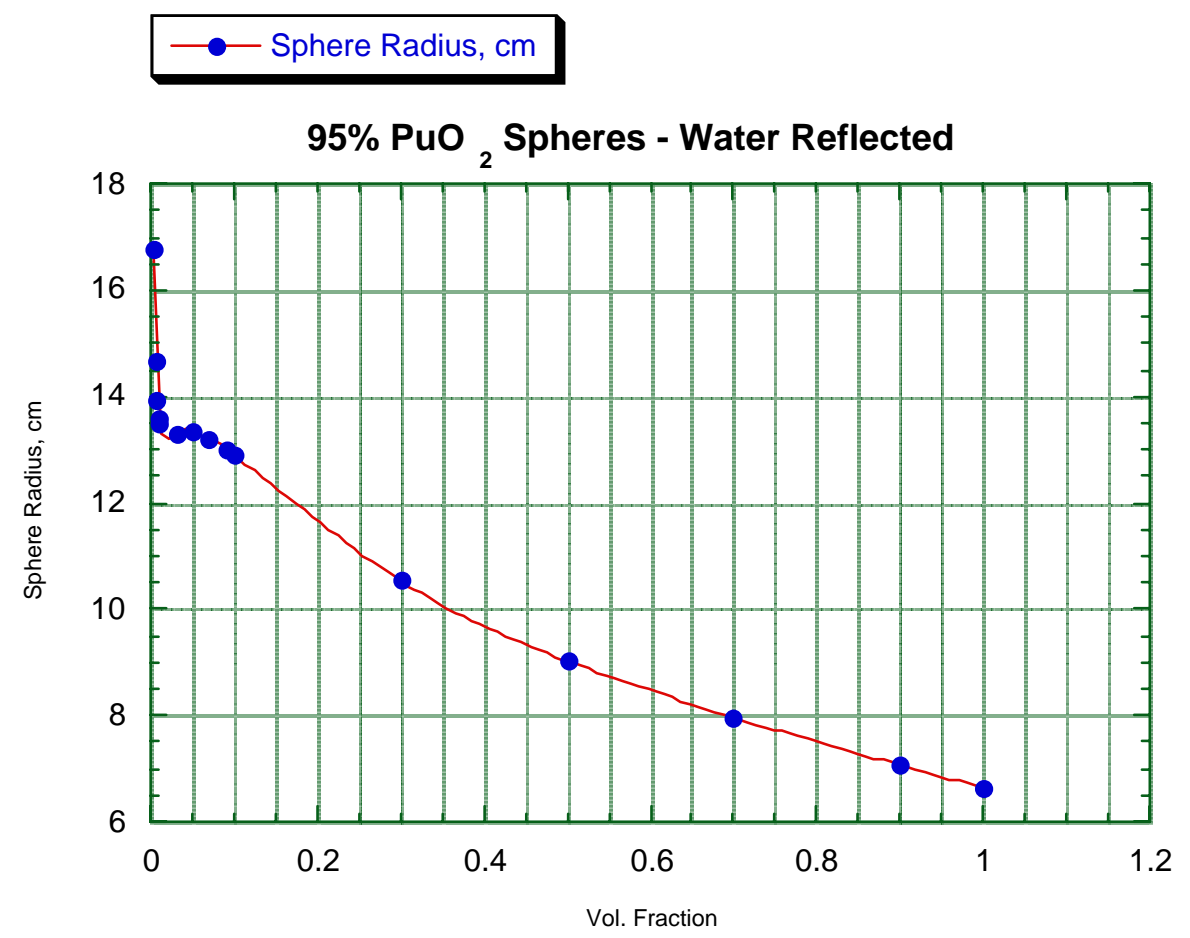

Fig. C.2. Radius vs volume fraction for $95 \%$ enriched $\mathrm{PuO}_{2}-\mathrm{H}_{2} \mathrm{O}$ spheres. 


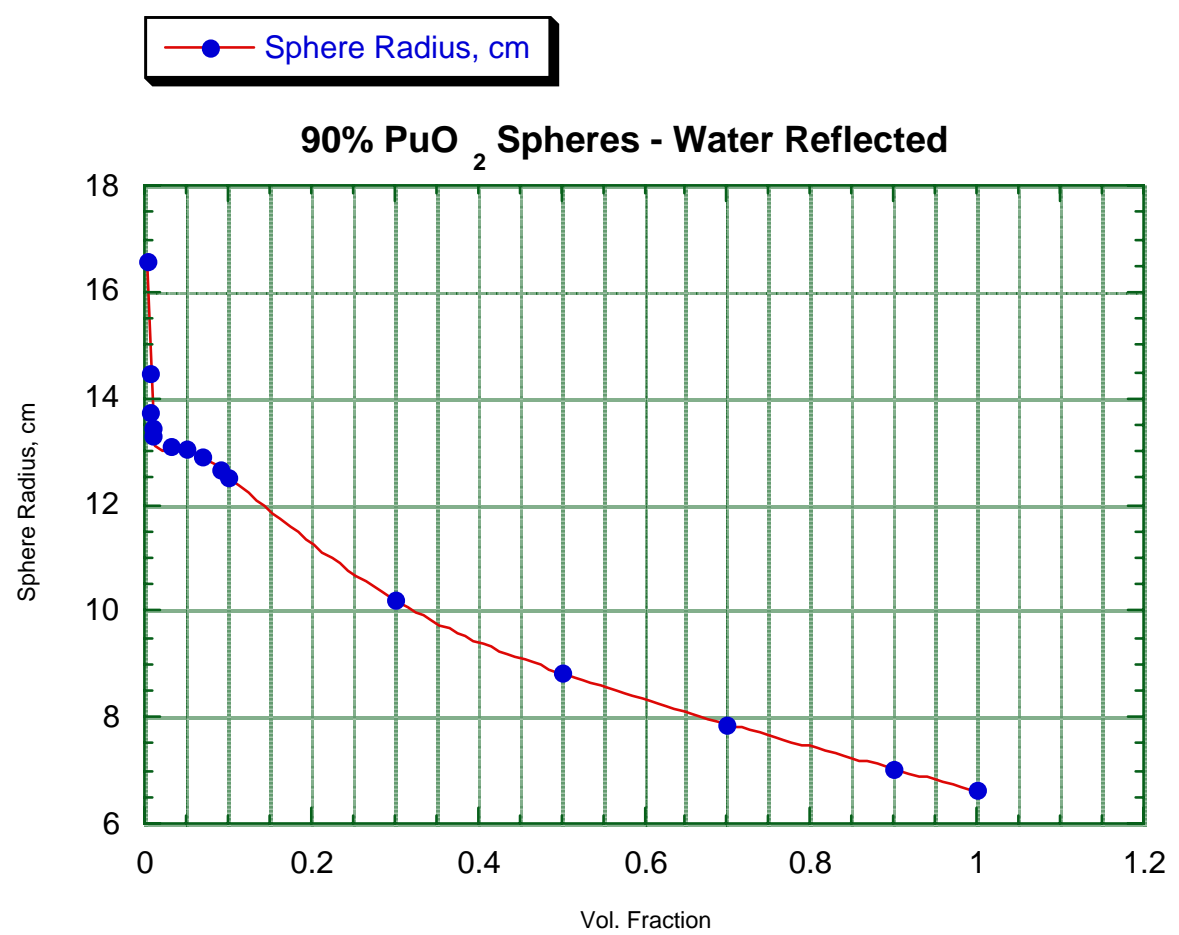

Fig. C.3. Radius vs volume fraction for $90 \%$ enriched $\mathrm{PuO}_{2}-\mathrm{H}_{2} \mathrm{O}$ spheres.

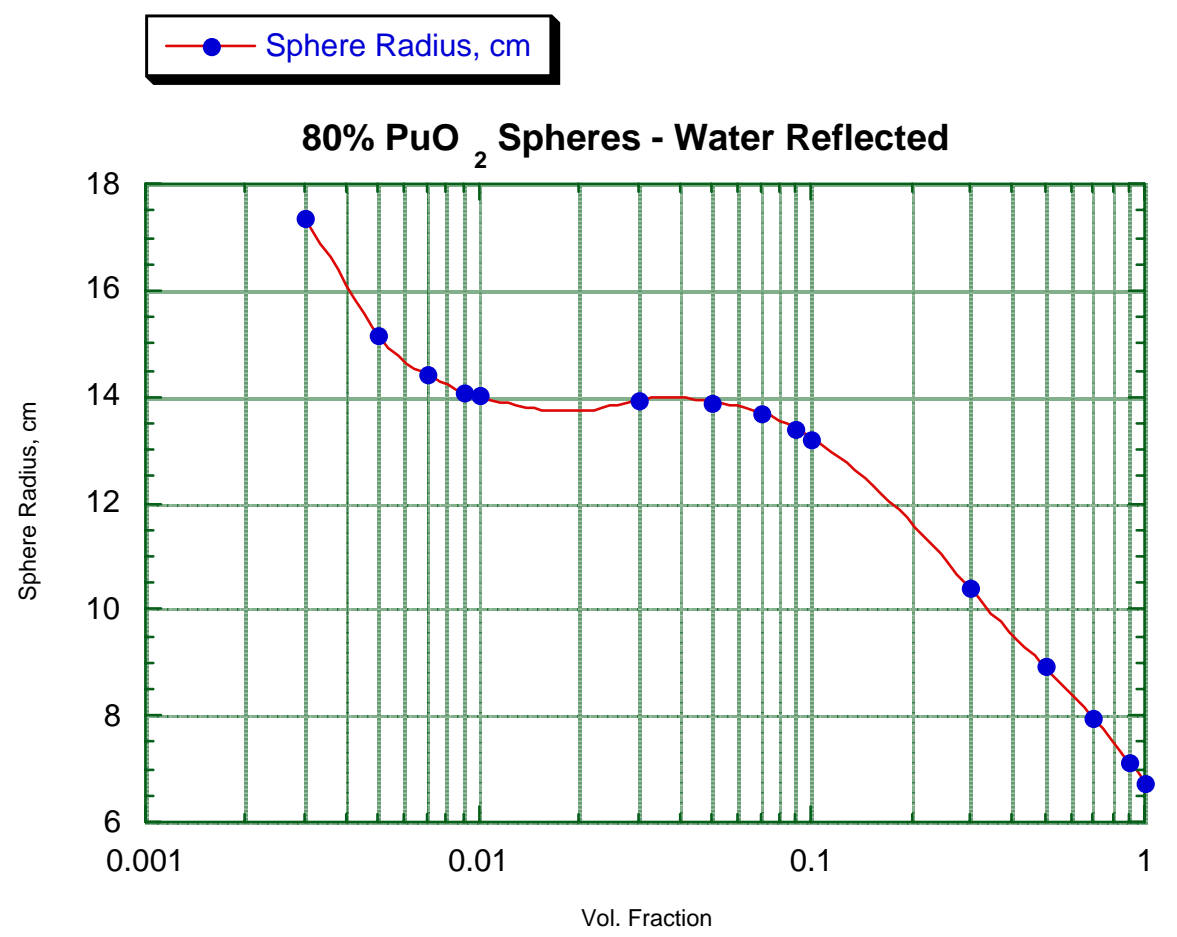

Fig. C.4. Radius vs volume fraction for $80 \%$ enriched $\mathrm{PuO}_{2}-\mathrm{H}_{2} \mathrm{O}$ spheres. 


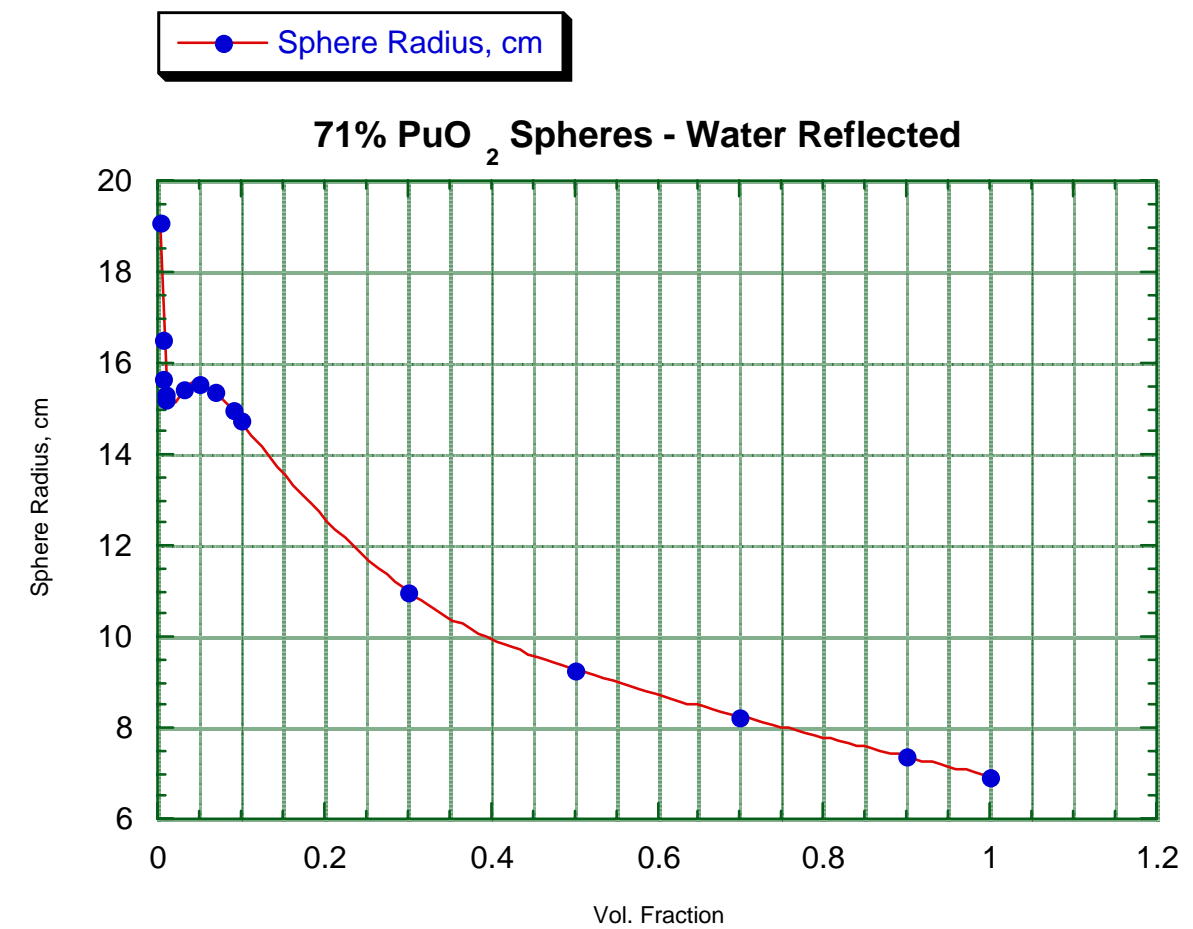

Fig. C.5. Radius vs volume fraction for $71 \%$ enriched $\mathrm{PuO}_{2}-\mathrm{H}_{2} \mathrm{O}$ spheres. 


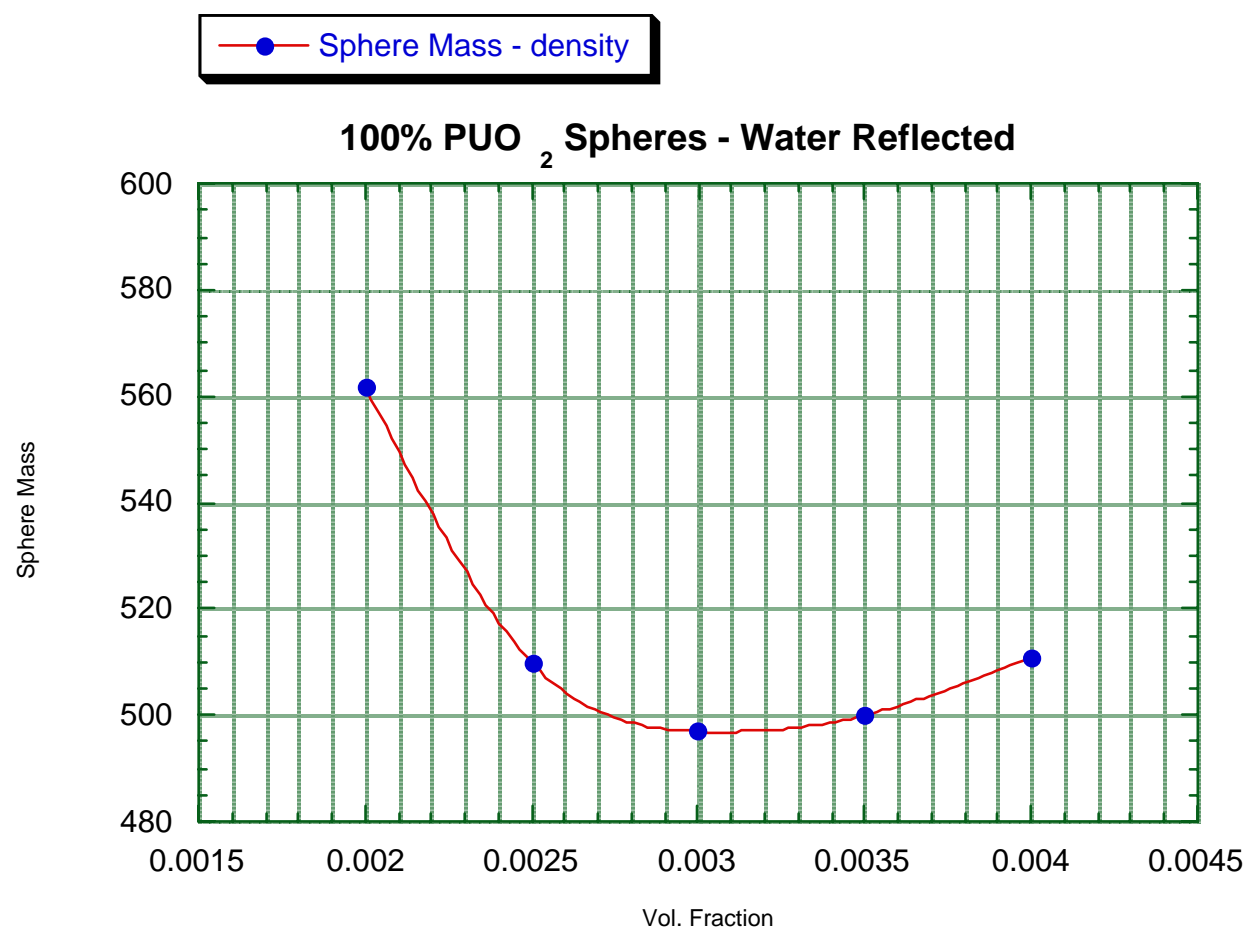

Fig. C.6. Mass vs volume fraction for $100 \%$ enriched $\mathrm{PuO}_{2}-\mathrm{H}_{2} \mathrm{O}$ spheres.

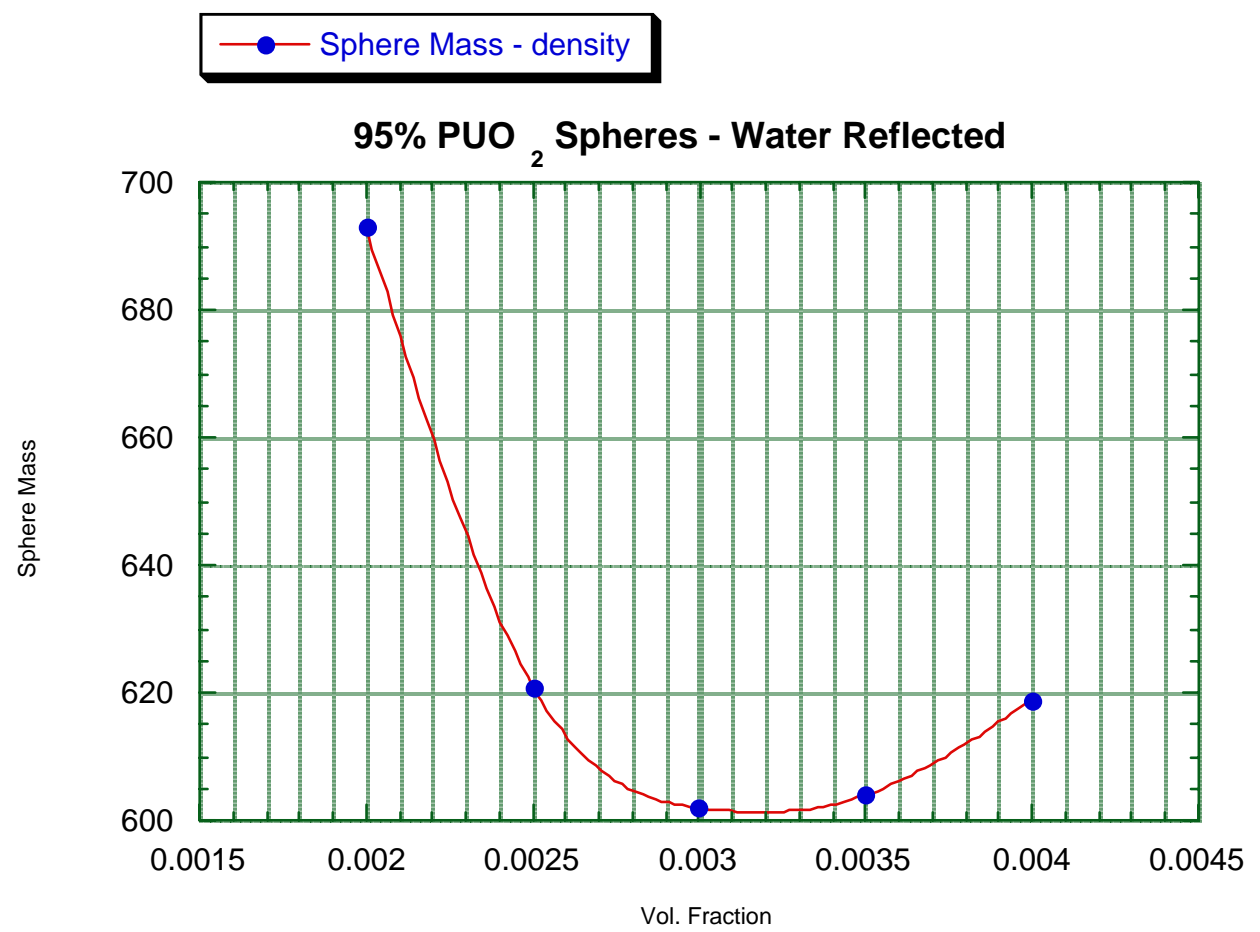

Fig. C.7. Mass vs volume fraction for $95 \%$ enriched $\mathrm{PuO}_{2}-\mathrm{H}_{2} \mathrm{O}$ spheres. 


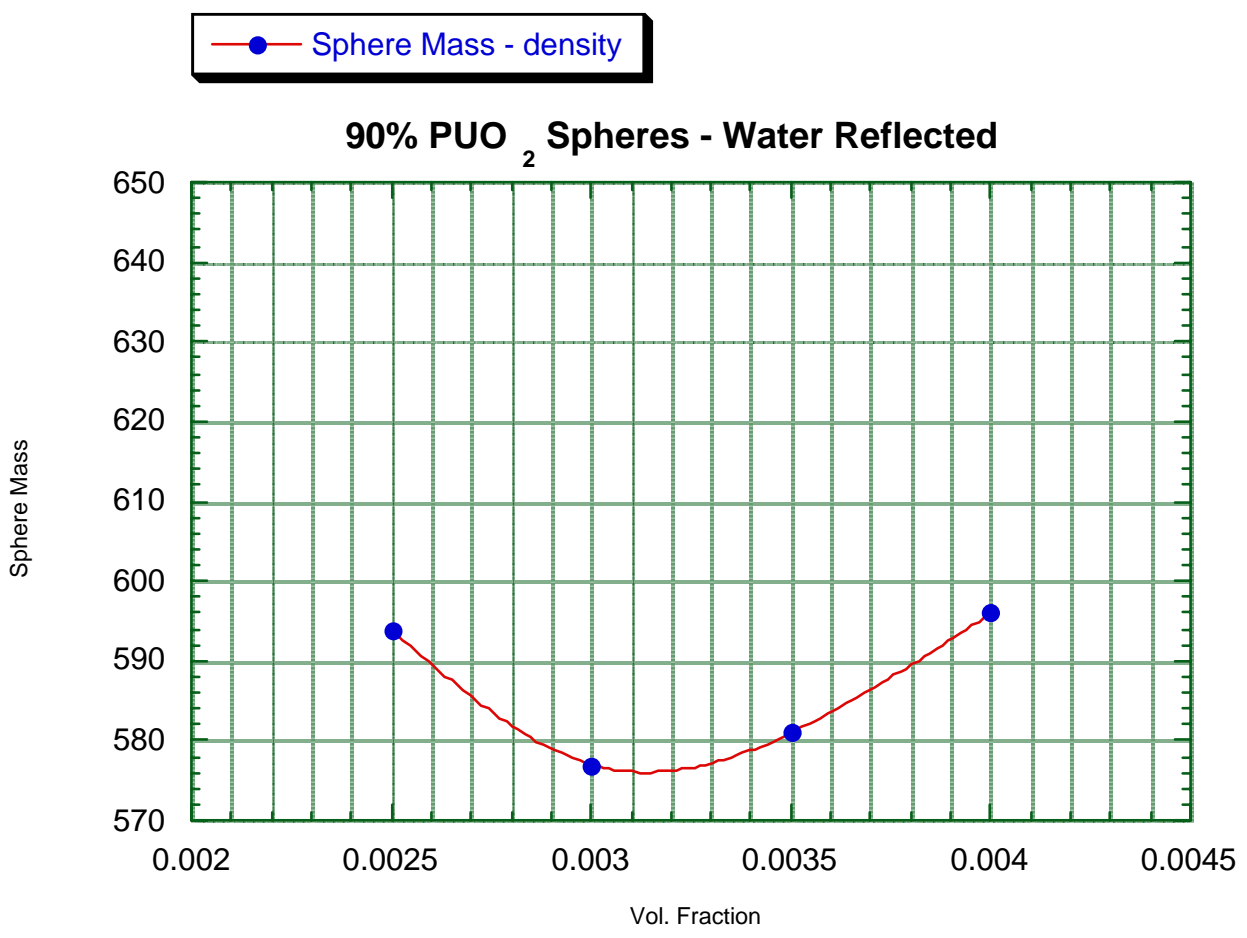

Fig. C.8. Mass vs volume fraction for $90 \%$ enriched $\mathrm{PuO}_{2}-\mathrm{H}_{2} \mathrm{O}$ spheres.

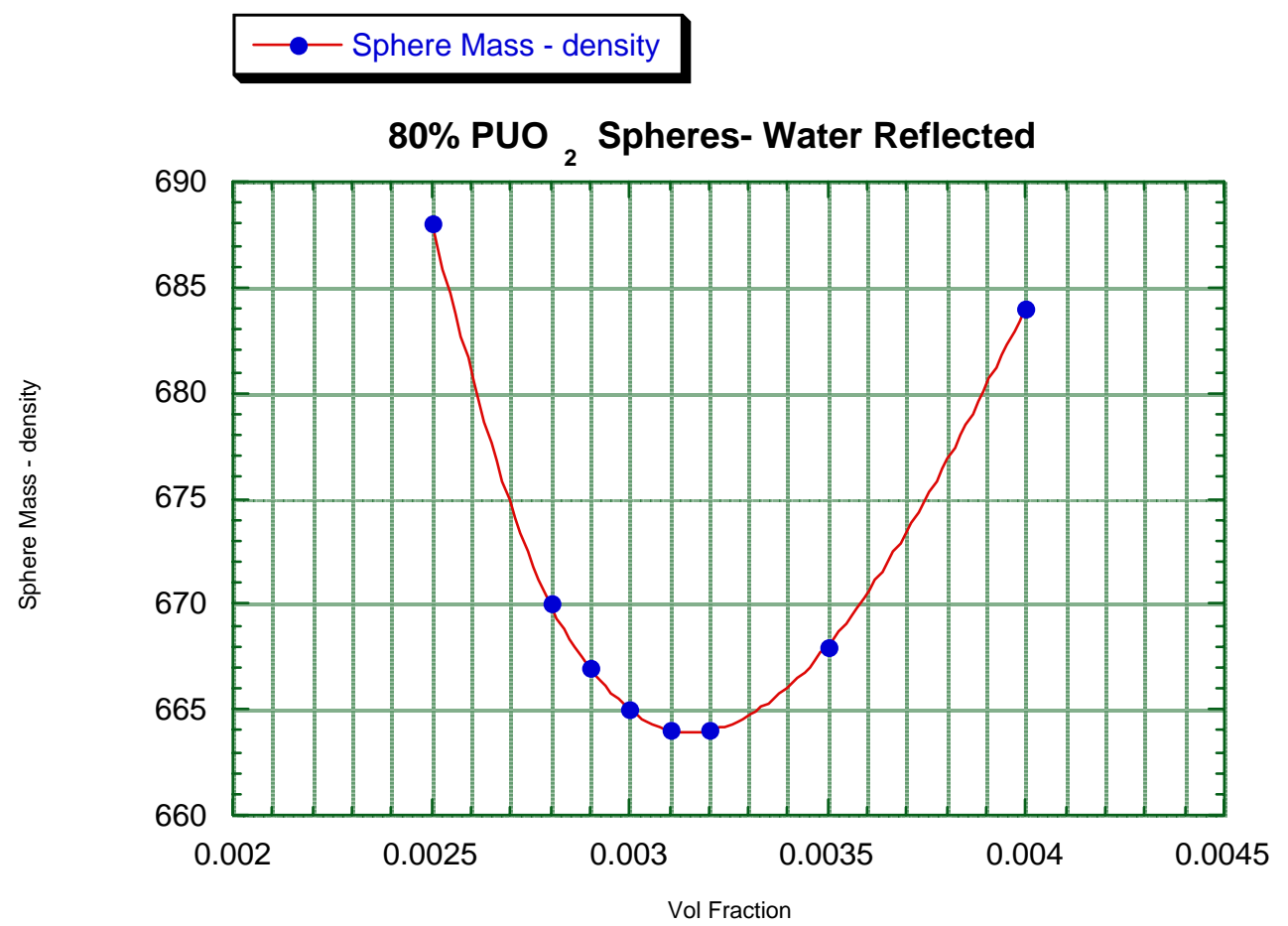

Fig. C.9. Mass vs volume fraction for $80 \%$ enriched $\mathrm{PuO}_{2}-\mathrm{H}_{2} \mathrm{O}$ spheres. 


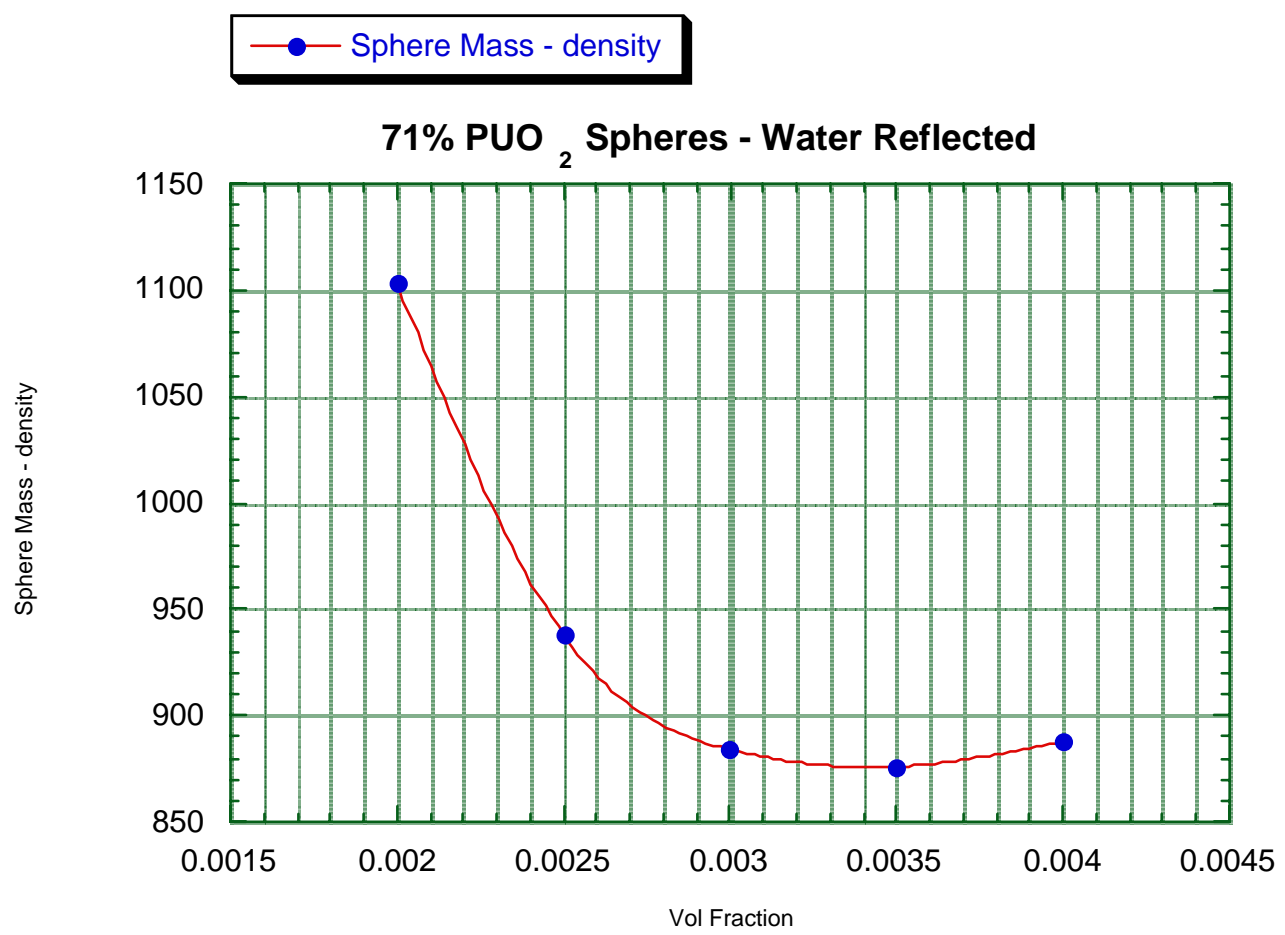

Fig. C.10. Mass vs volume fraction for $71 \%$ enriched $\mathrm{PuO}_{2}-\mathrm{H}_{2} \mathrm{O}$ spheres. 


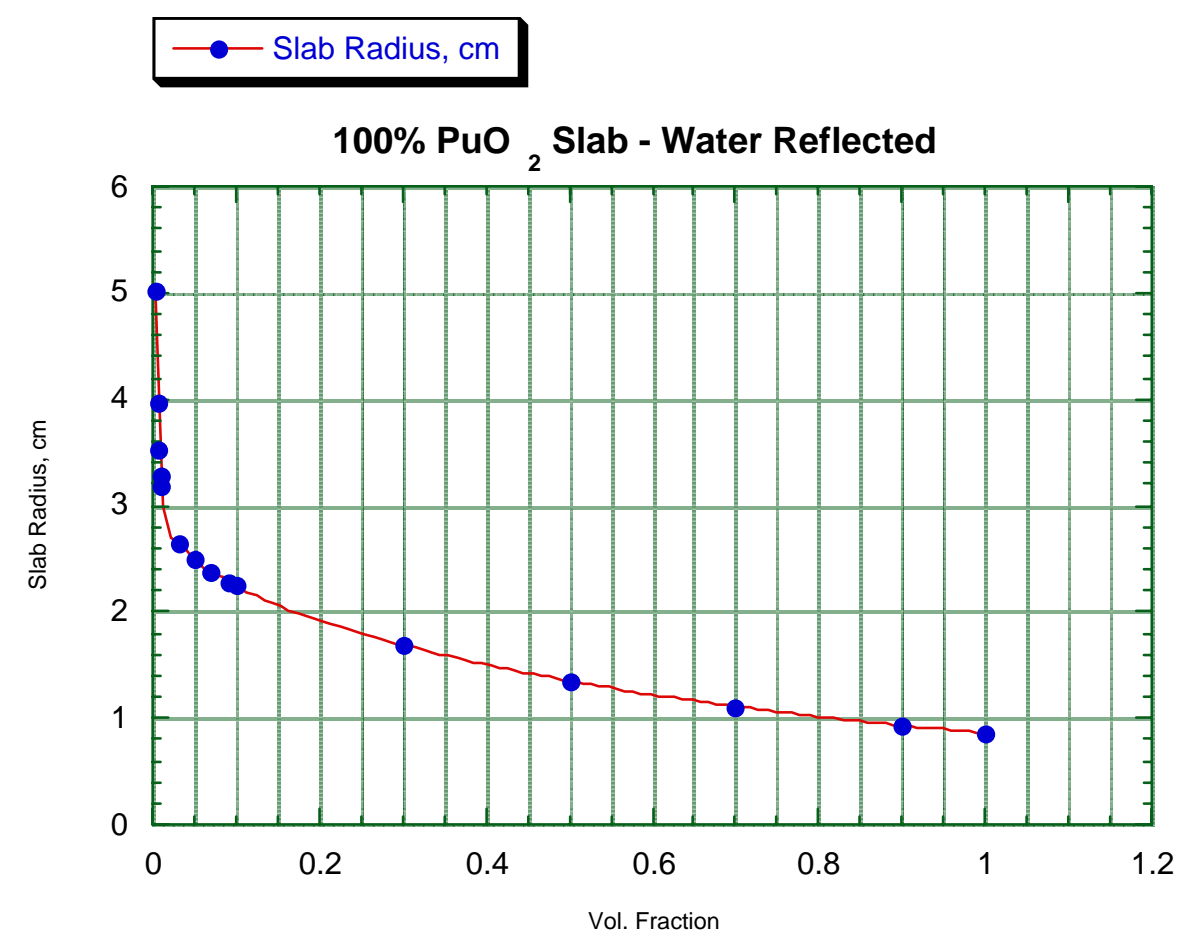

Fig. C.11. Radius vs volume fraction for $100 \%$ enriched $\mathrm{PuO}_{2}-\mathrm{H}_{2} \mathrm{O}$ slabs.

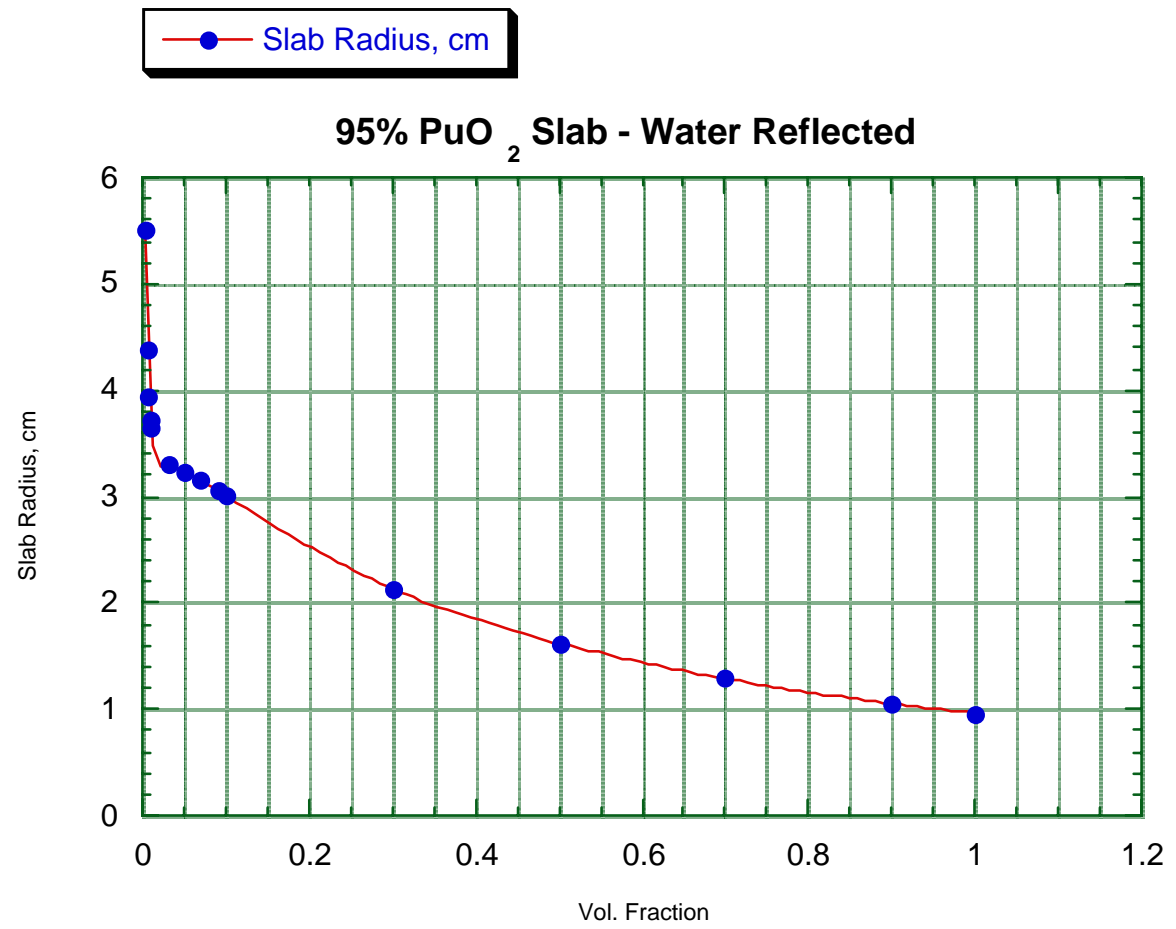

Fig. C.12. Radius vs volume fraction for $95 \%$ enriched $\mathrm{PuO}_{2}-\mathrm{H}_{2} \mathrm{O}$ slabs. 


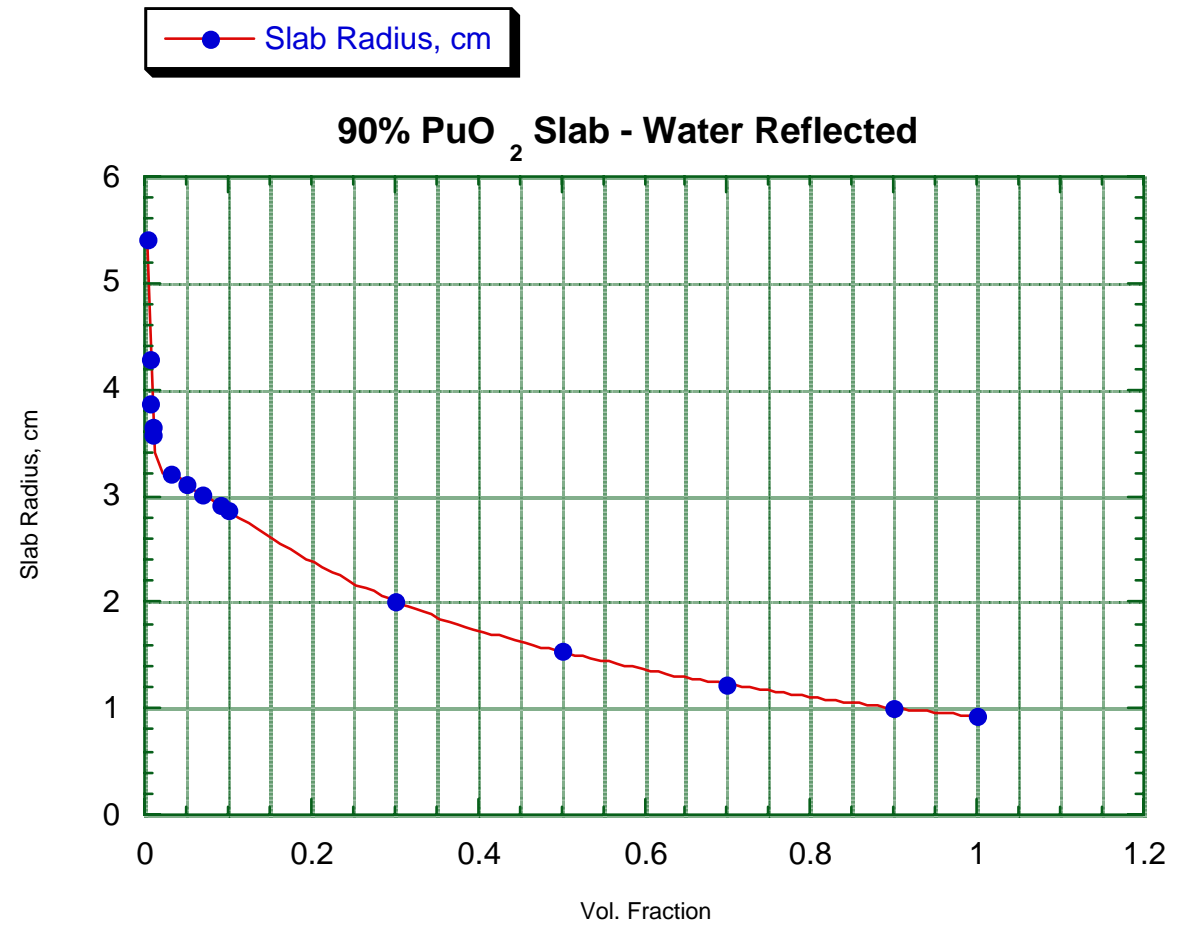

Fig. C.13. Radius vs volume fraction for $90 \%$ enriched $\mathrm{PuO}_{2}-\mathrm{H}_{2} \mathrm{O}$ slabs.

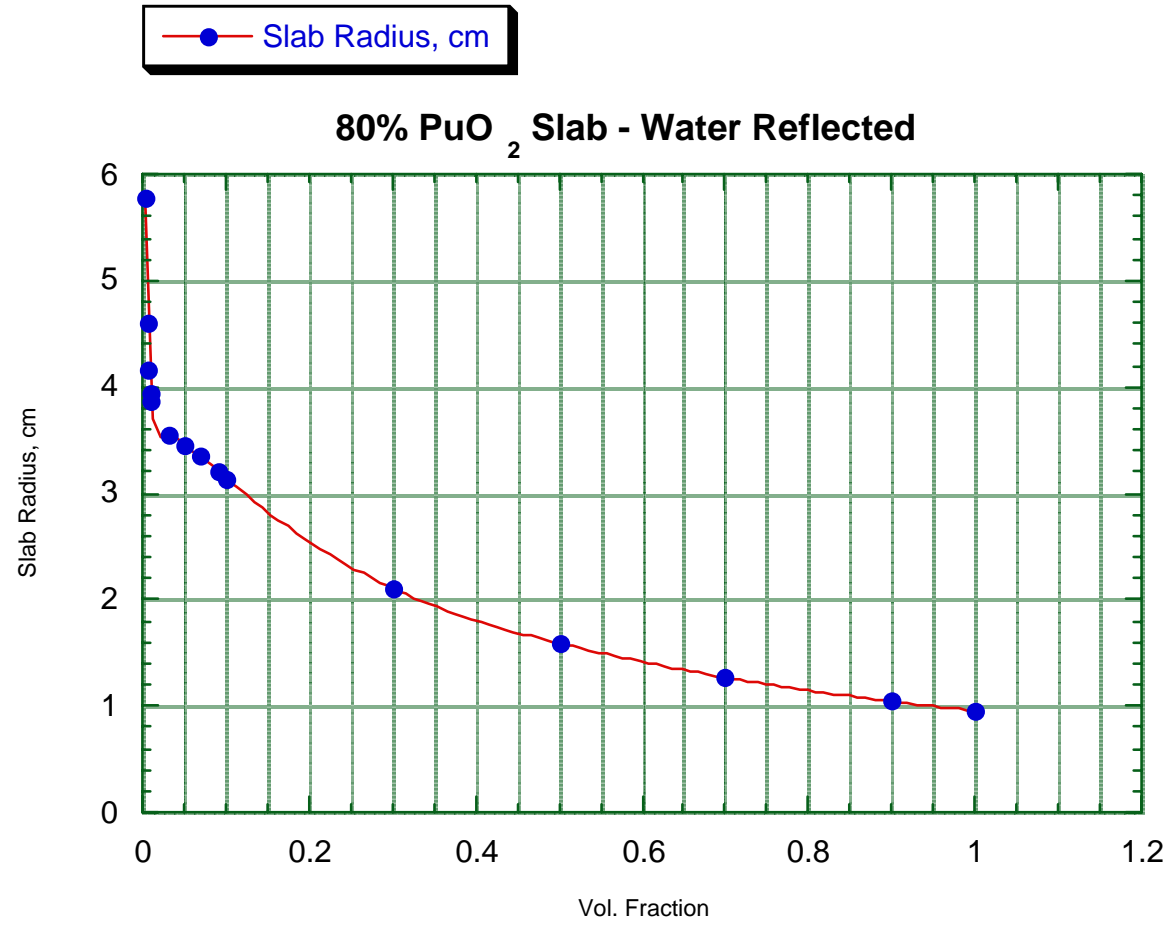

Fig. C.14. Radius vs volume fraction for $80 \%$ enriched $\mathrm{PuO}_{2}-\mathrm{H}_{2} \mathrm{O}$ slabs. 


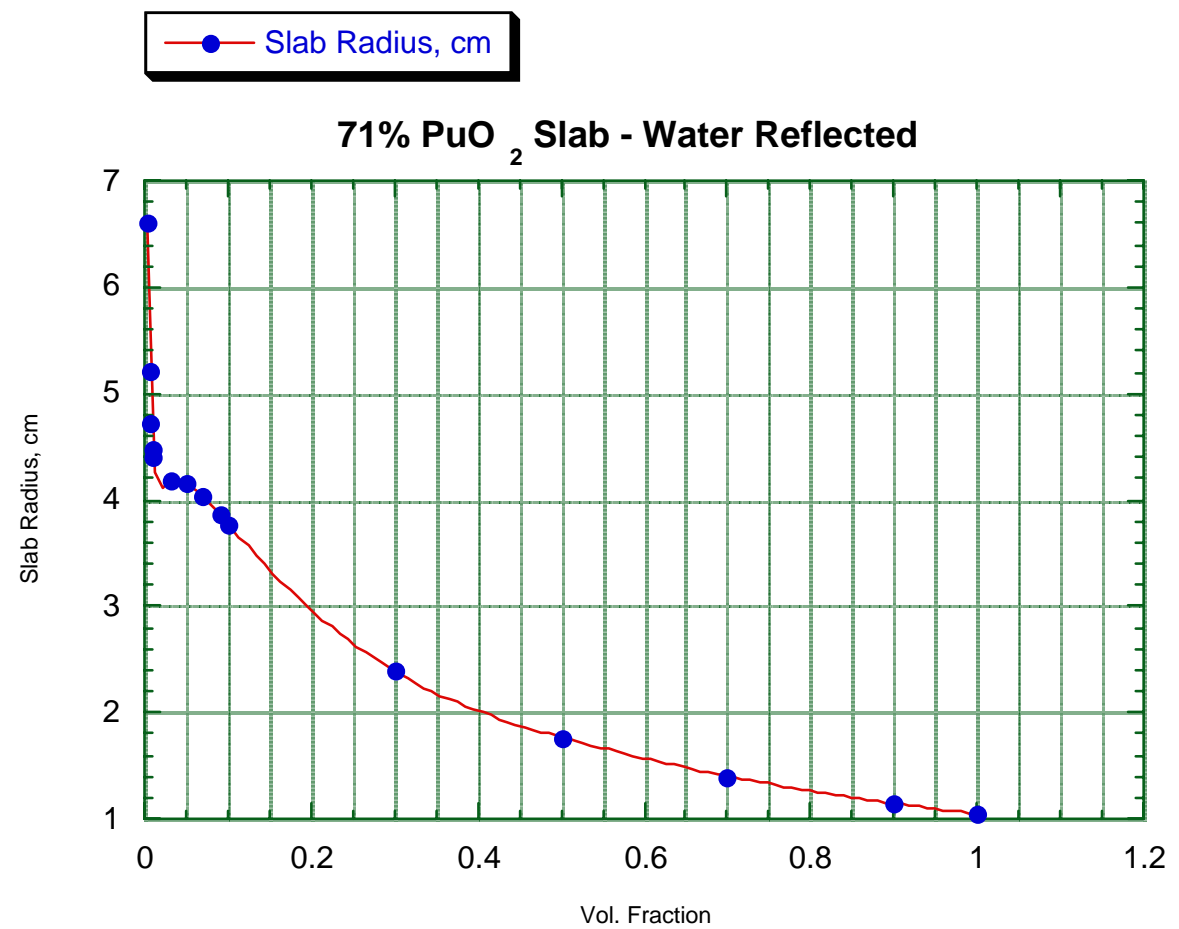

Fig. C.15. Radius vs volume fraction for $71 \%$ enriched $\mathrm{PuO}_{2}-\mathrm{H}_{2} \mathrm{O}$ slabs. 


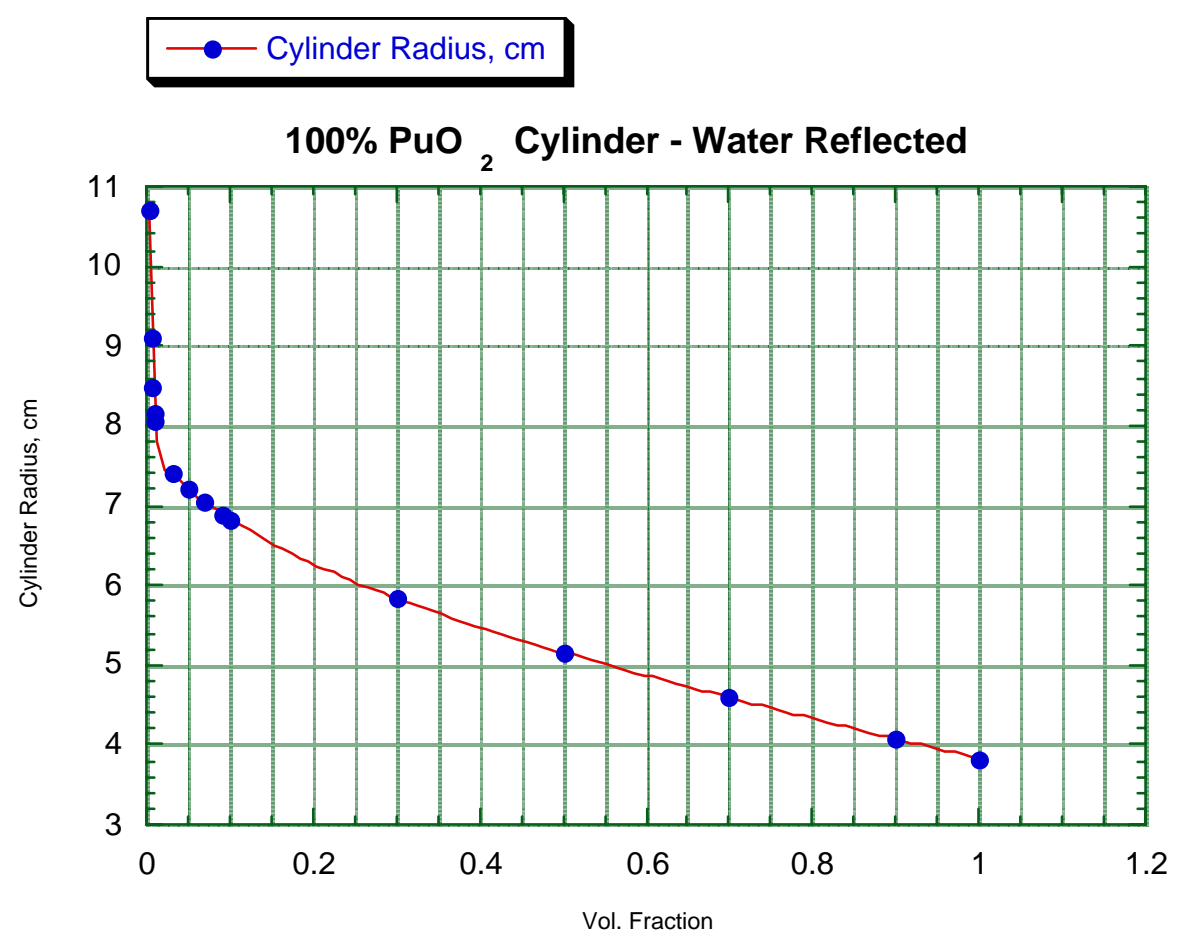

Fig. C.16. Radius vs volume fraction for $100 \%$ enriched $\mathrm{PuO}_{2}-\mathrm{H}_{2} \mathrm{O}$ cylinders.

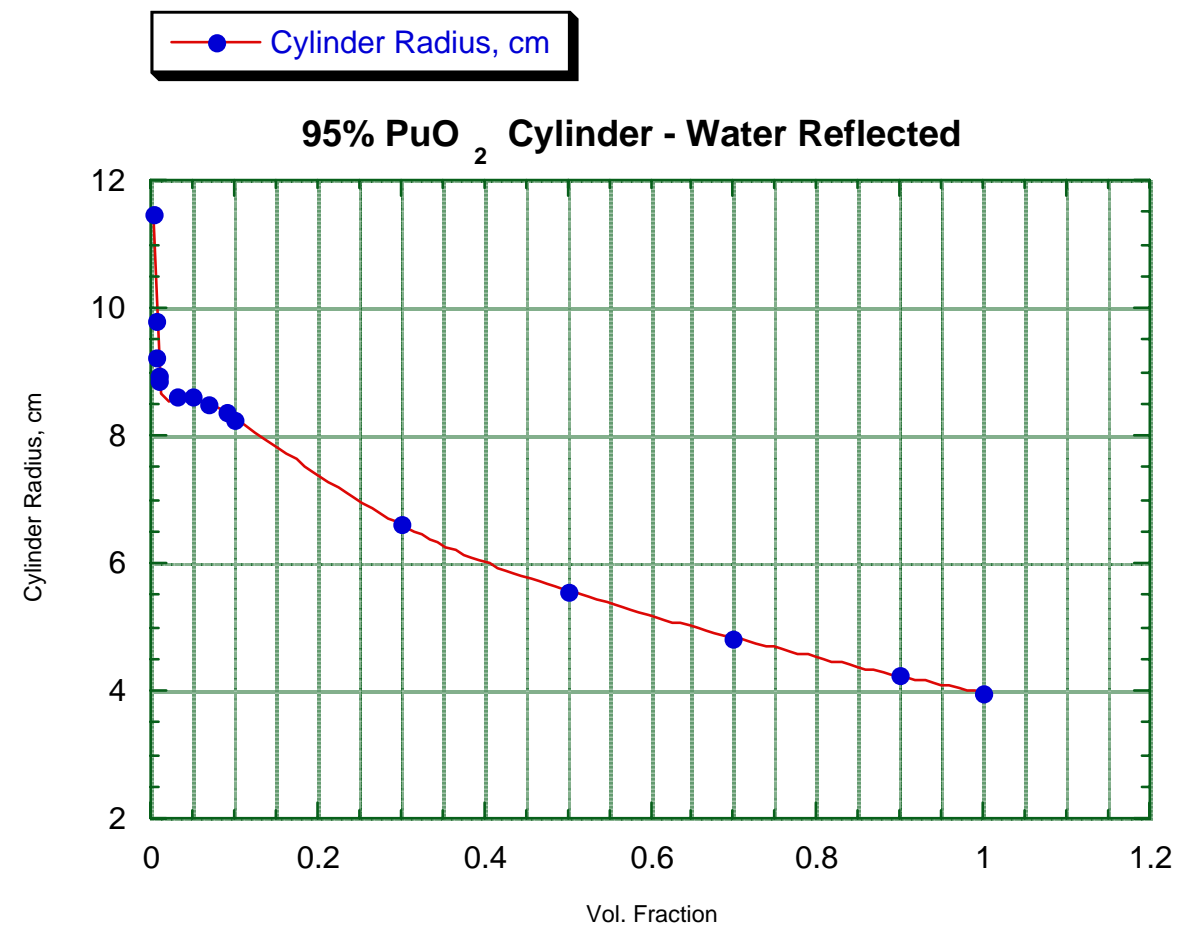

Fig. C.17. Radius vs volume fraction for $95 \%$ enriched $\mathrm{PuO}_{2}-\mathrm{H}_{2} \mathrm{O}$ cylinders. 


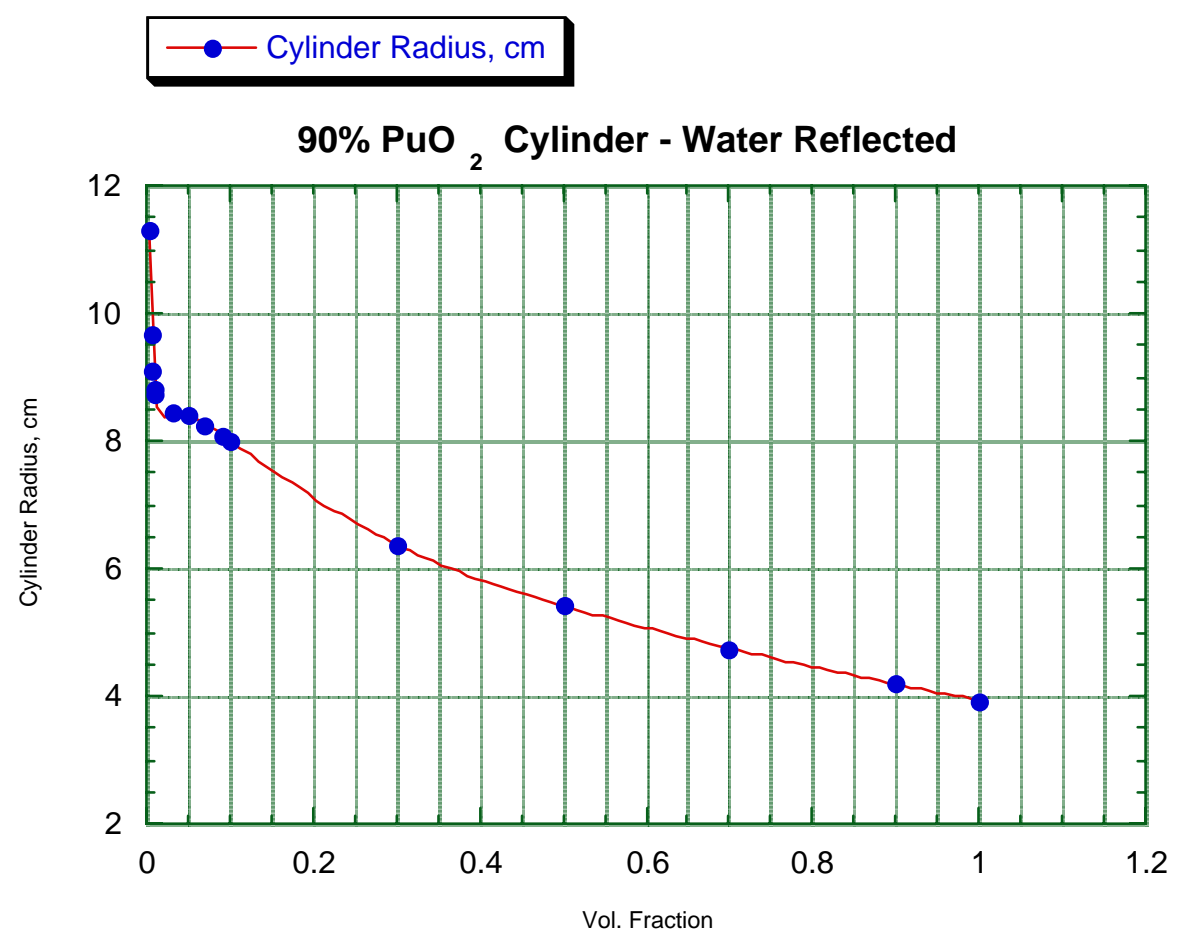

Fig. C.18. Radius vs volume fraction for $90 \%$ enriched $\mathrm{PuO}_{2}-\mathrm{H}_{2} \mathrm{O}$ cylinders.

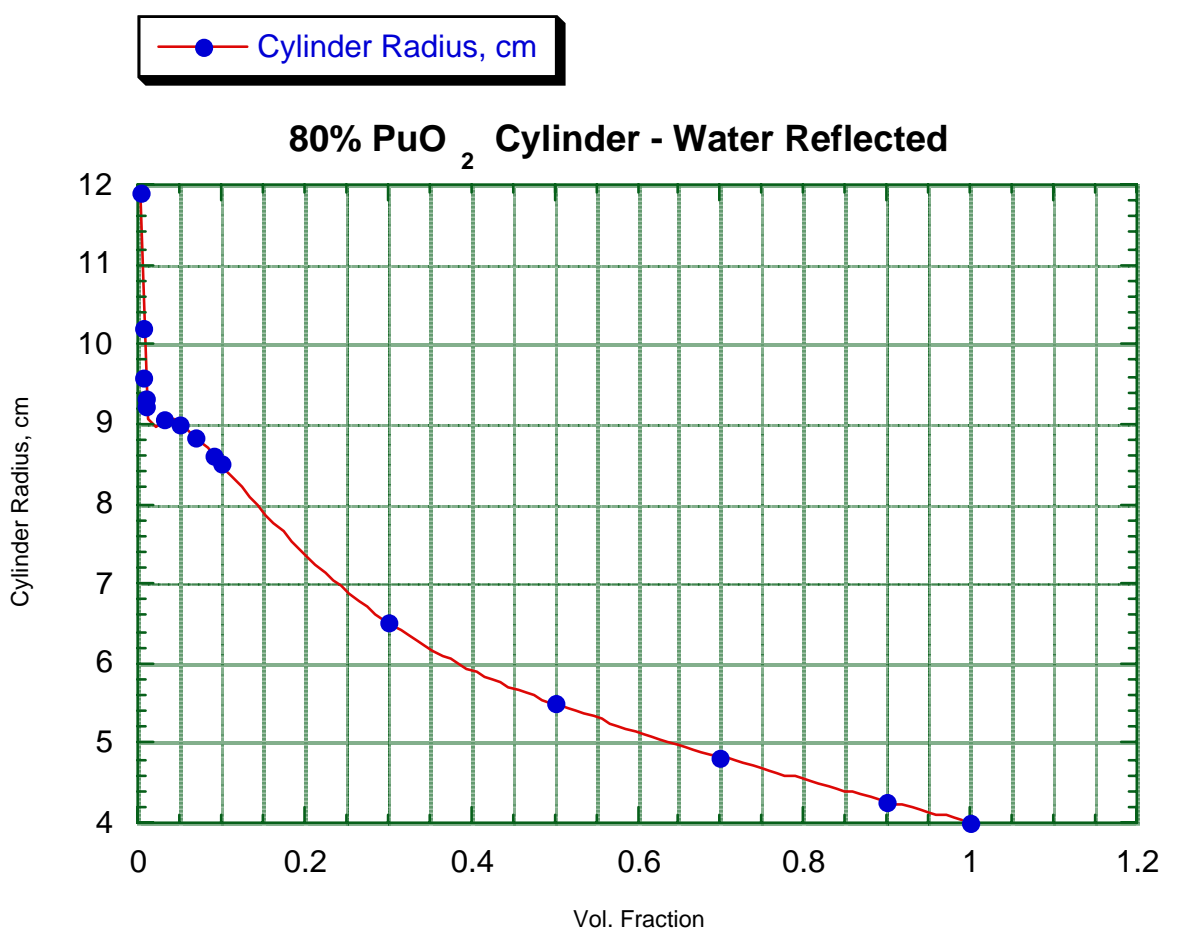

Fig. C.19. Radius vs volume fraction for $80 \%$ enriched $\mathrm{PuO}_{2}-\mathrm{H}_{2} \mathrm{O}$ cylinders. 


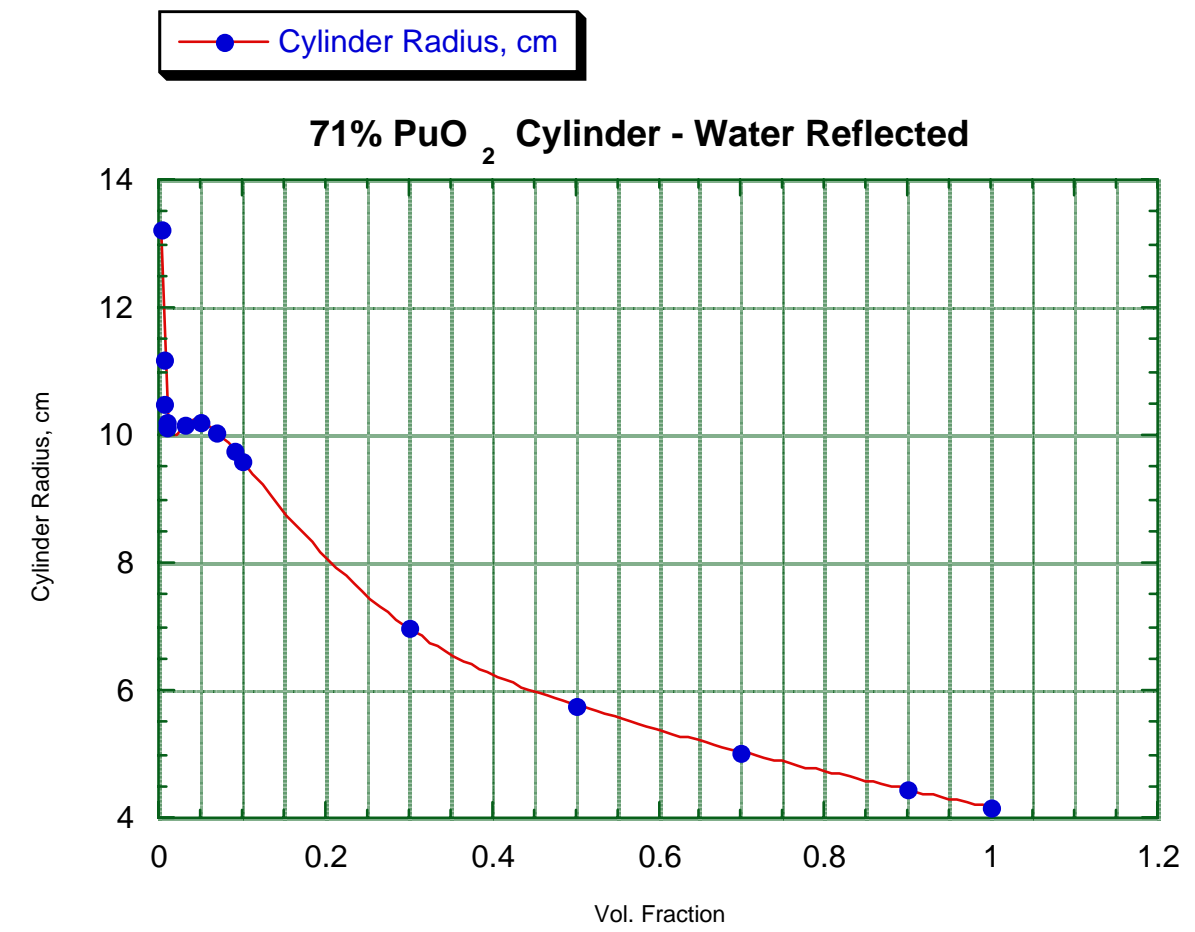

Fig. C.20. Radius vs volume fraction for $71 \%$ enriched $\mathrm{PuO}_{2}-\mathrm{H}_{2} \mathrm{O}$ cylinders. 
APPENDIX D

GRAPHS OF PUNH- $\mathrm{H}_{2} \mathrm{O}$, WATER REFLECTED (30 cm): CRITICAL PARAMETERS vs PLUTONIUM DENSITY 



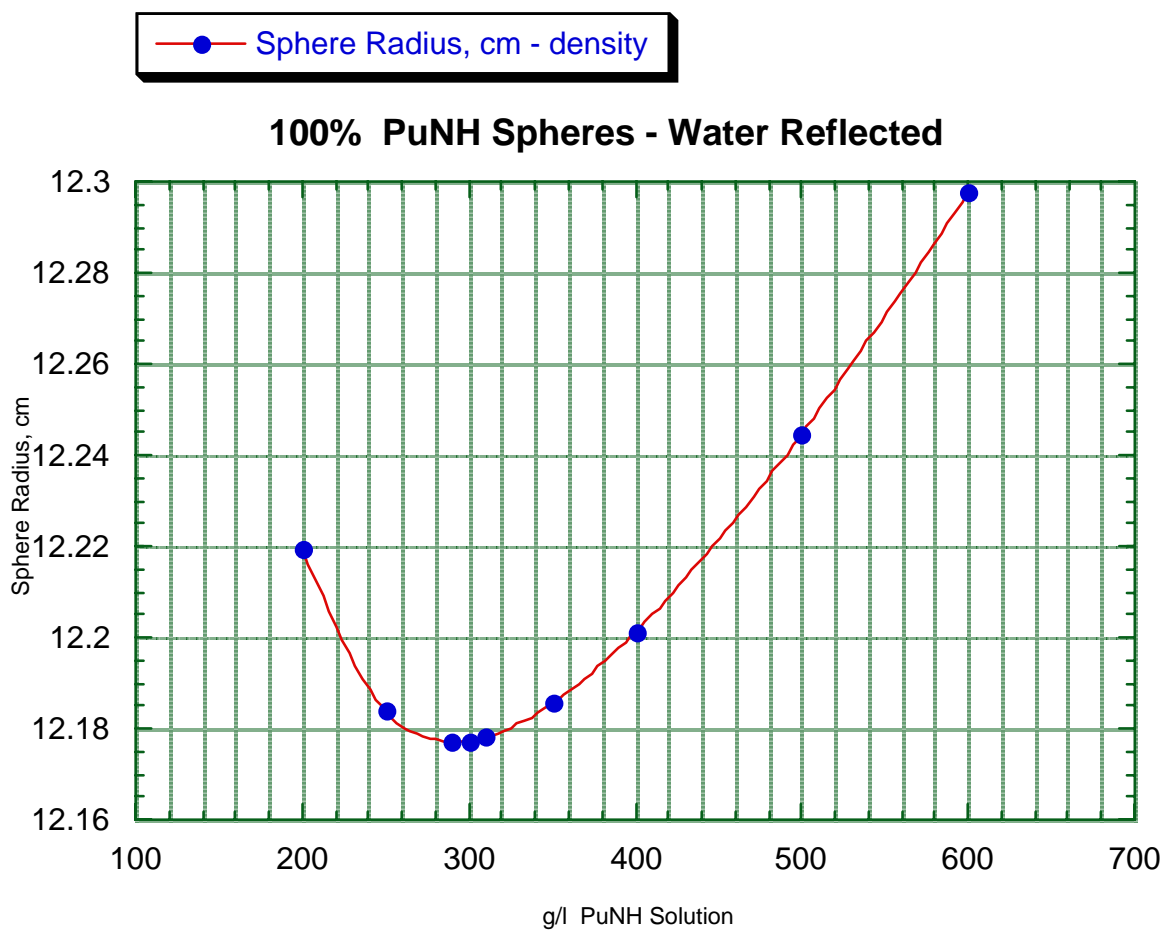

Fig. D.1. Radius vs density for $100 \%$ enriched $\mathrm{PuNH}-\mathrm{H}_{2} \mathrm{O}$ spheres.

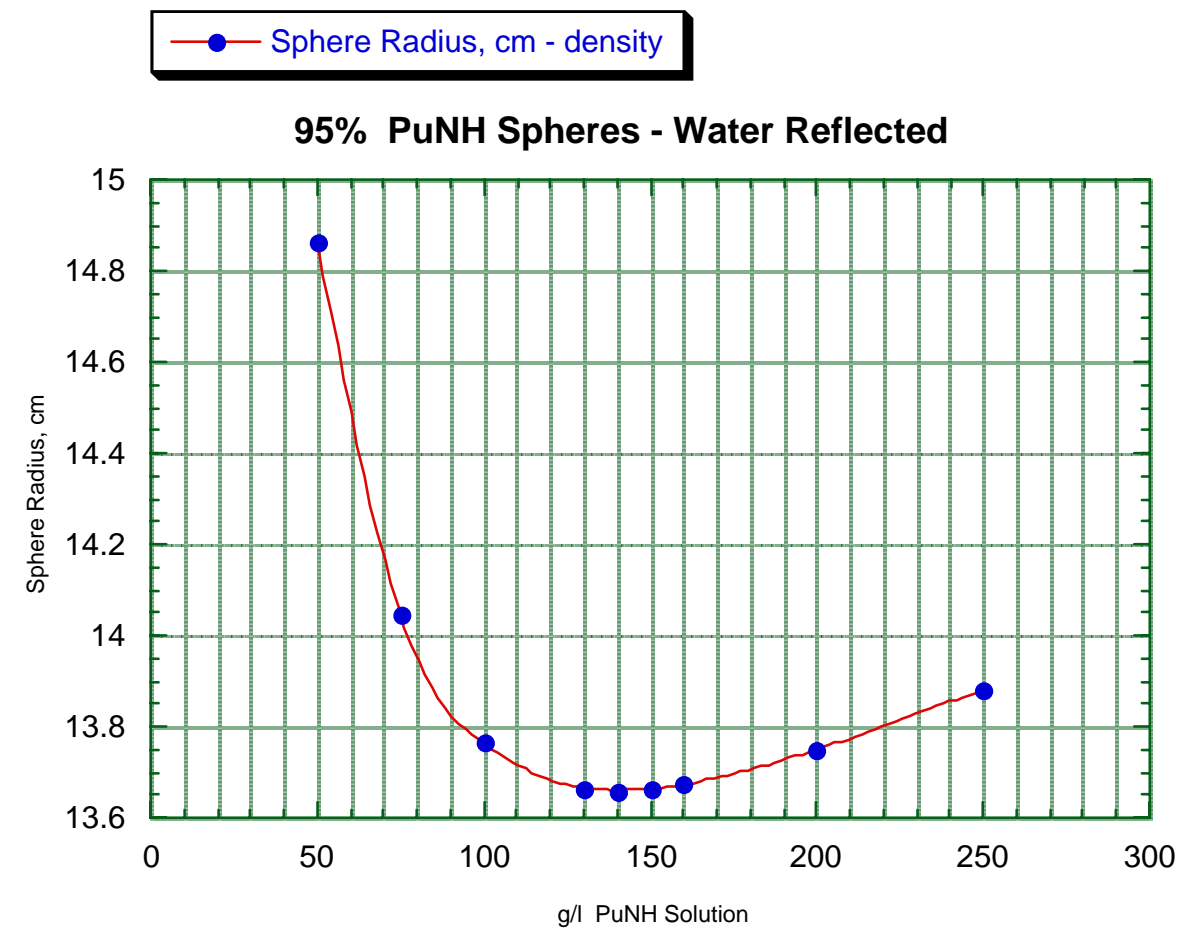

Fig. D.2. Radius vs density for $95 \%$ enriched $\mathrm{PuNH}-\mathrm{H}_{2} \mathrm{O}$ spheres. 


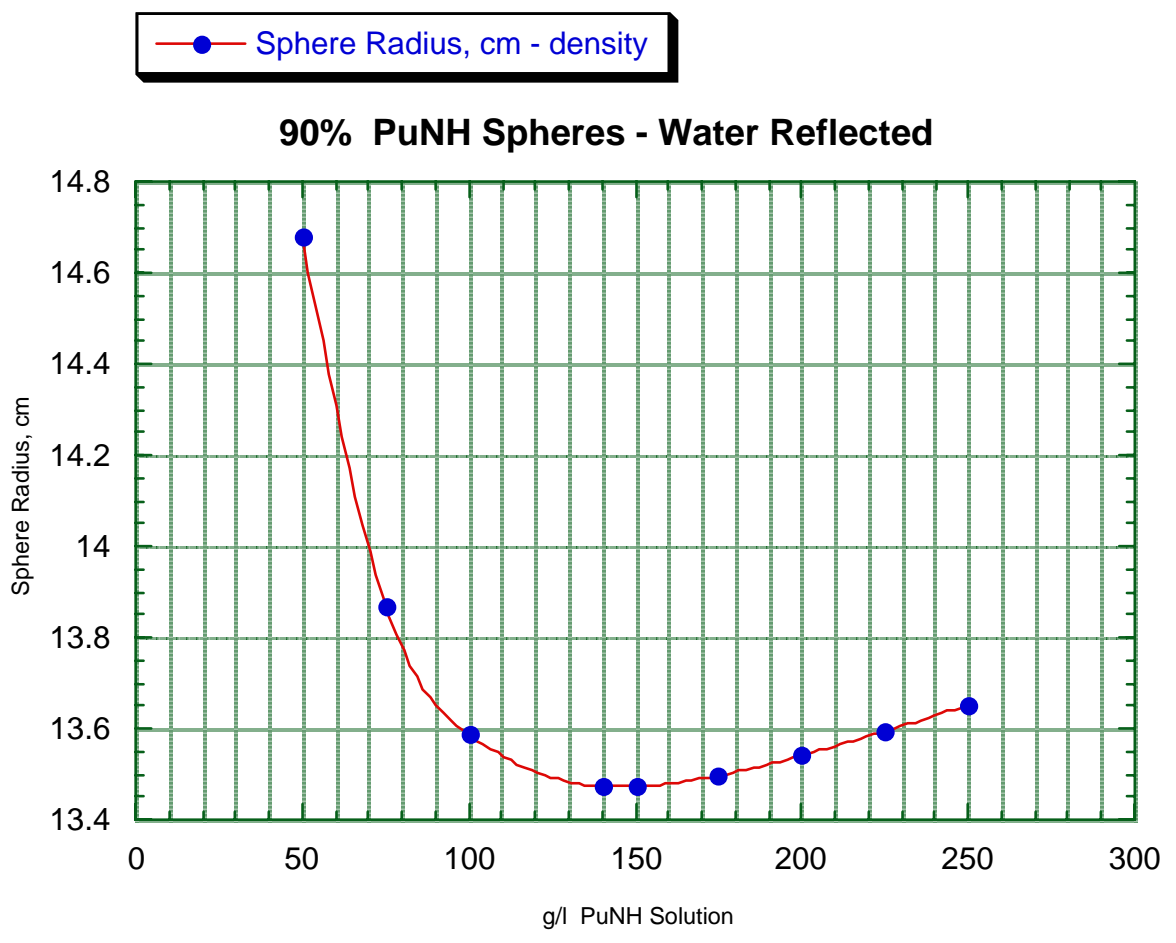

Fig. D.3. Radius vs density for $90 \%$ enriched $\mathrm{PuNH}-\mathrm{H}_{2} \mathrm{O}$ spheres.

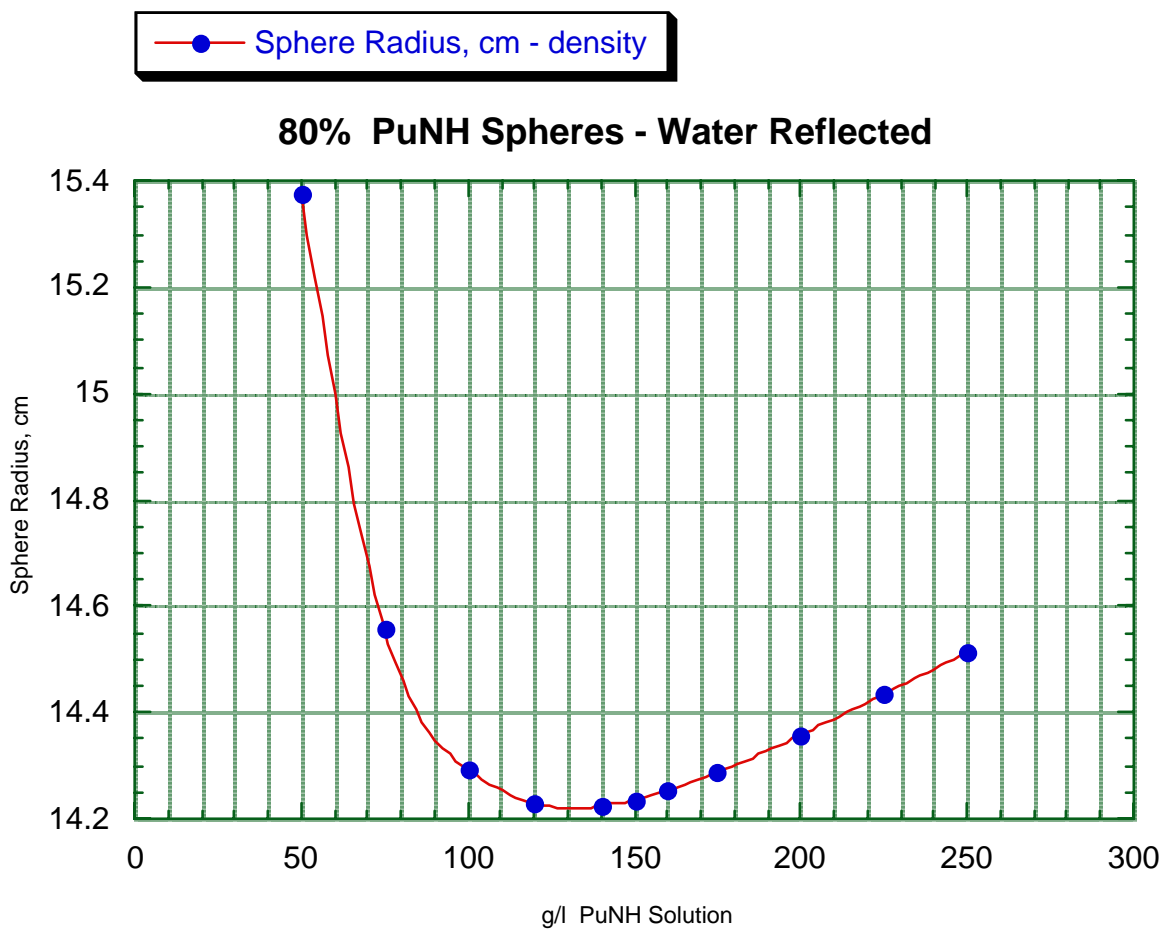

Fig. D.4. Radius vs density for $80 \%$ enriched $\mathrm{PuNH}-\mathrm{H}_{2} \mathrm{O}$ spheres. 


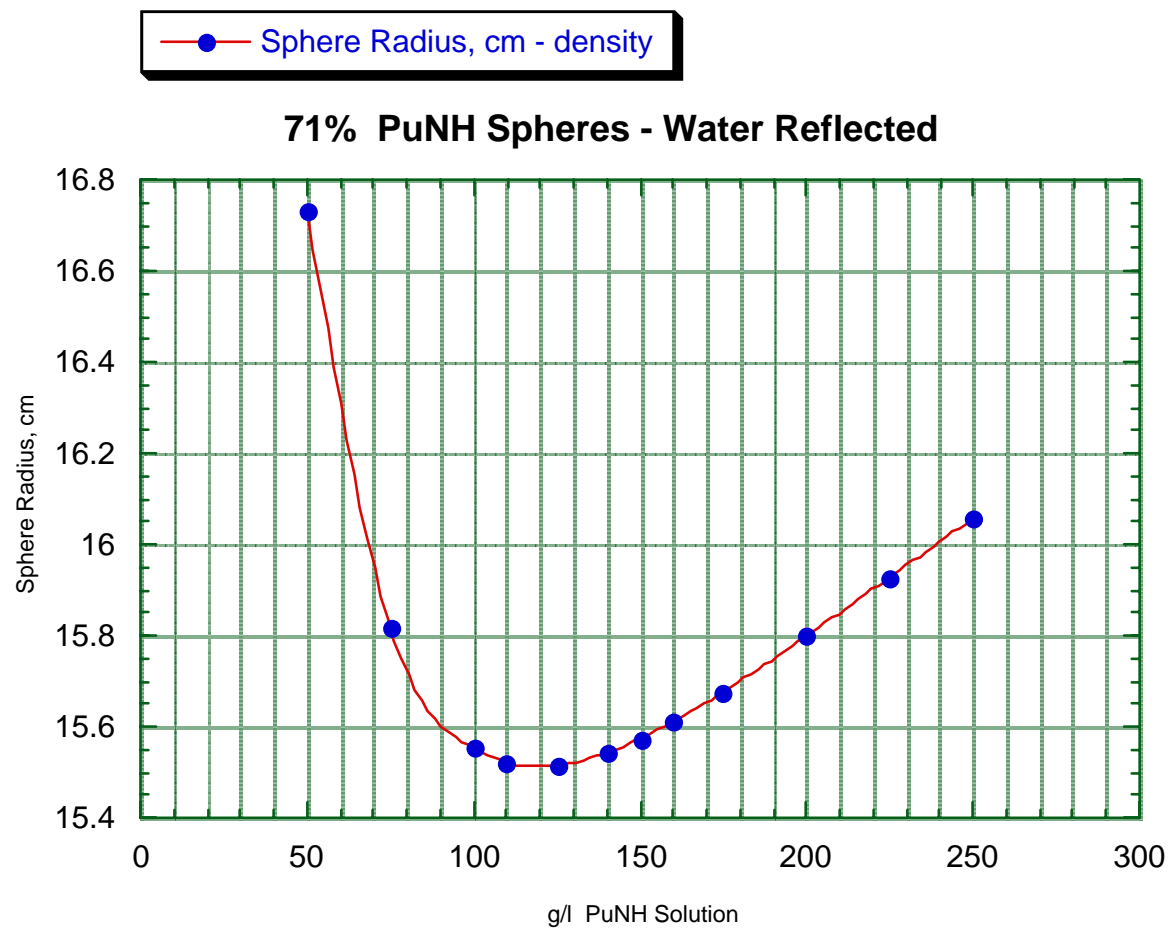

Fig. D.5. Radius vs density for $71 \%$ enriched $\mathrm{PuNH}-\mathrm{H}_{2} \mathrm{O}$ spheres. 


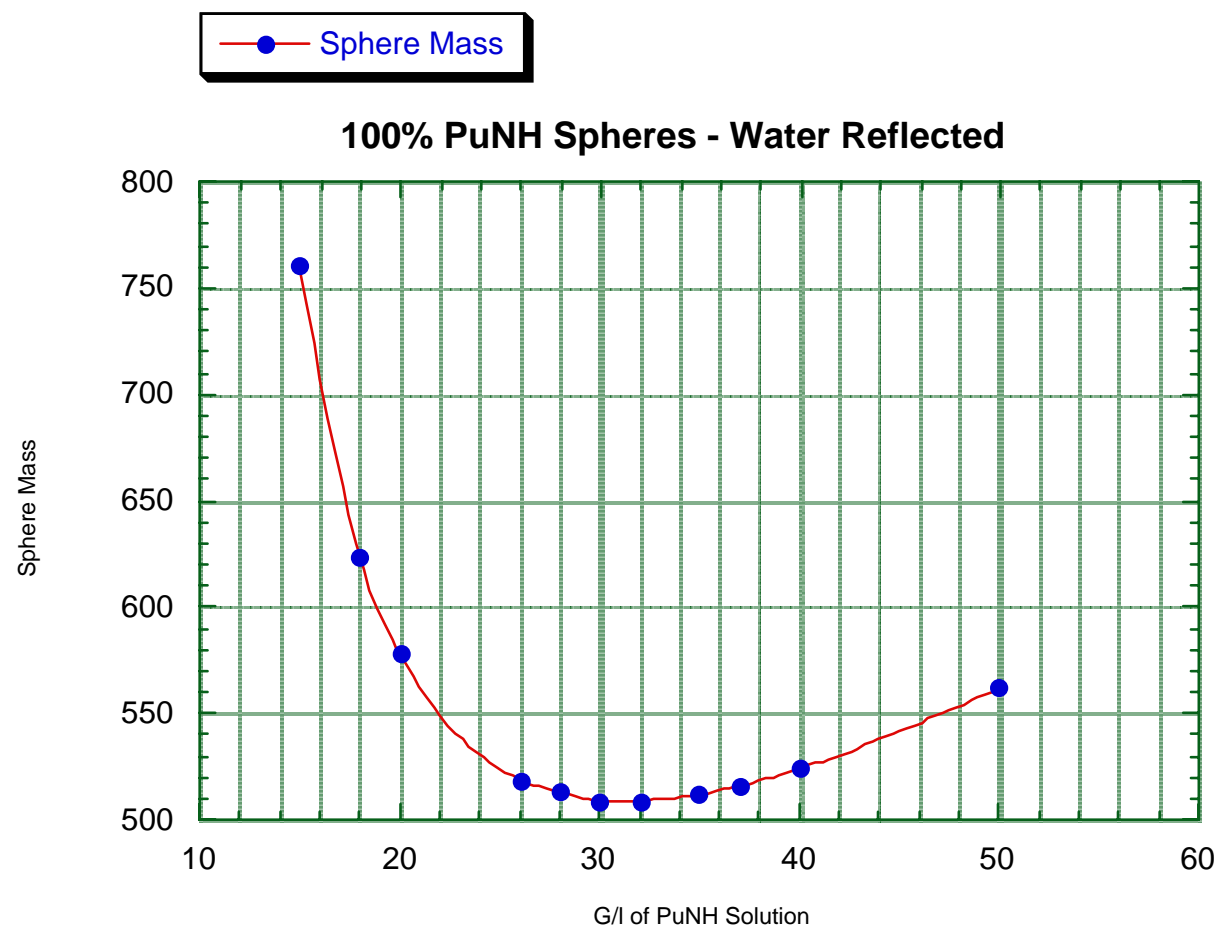

Fig. D.6. Mass vs density for $100 \%$ enriched $\mathrm{PuNH}-\mathrm{H}_{2} \mathrm{O}$ spheres.

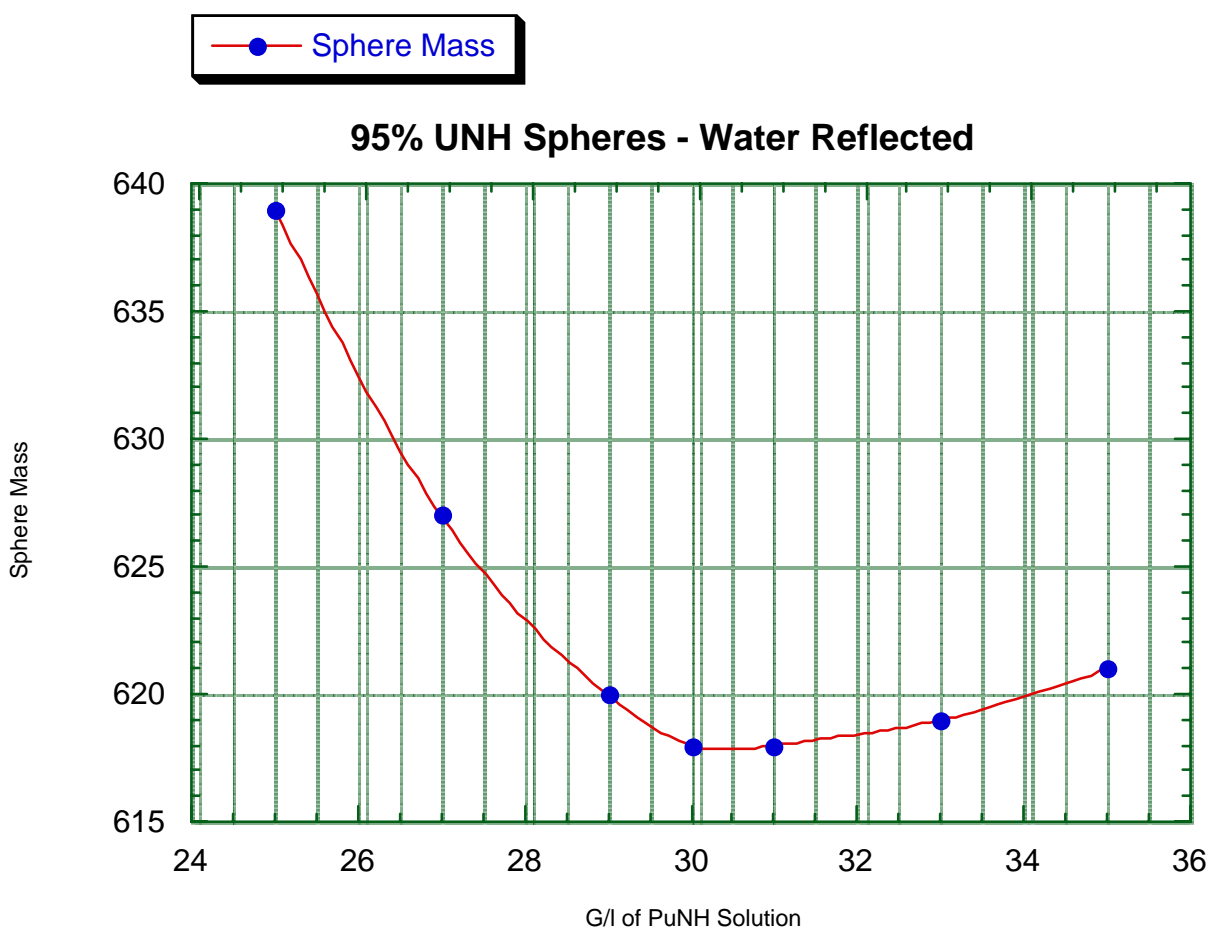

Fig. D.7. Mass vs density for $95 \%$ enriched $\mathrm{PuNH}-\mathrm{H}_{2} \mathrm{O}$ spheres. 


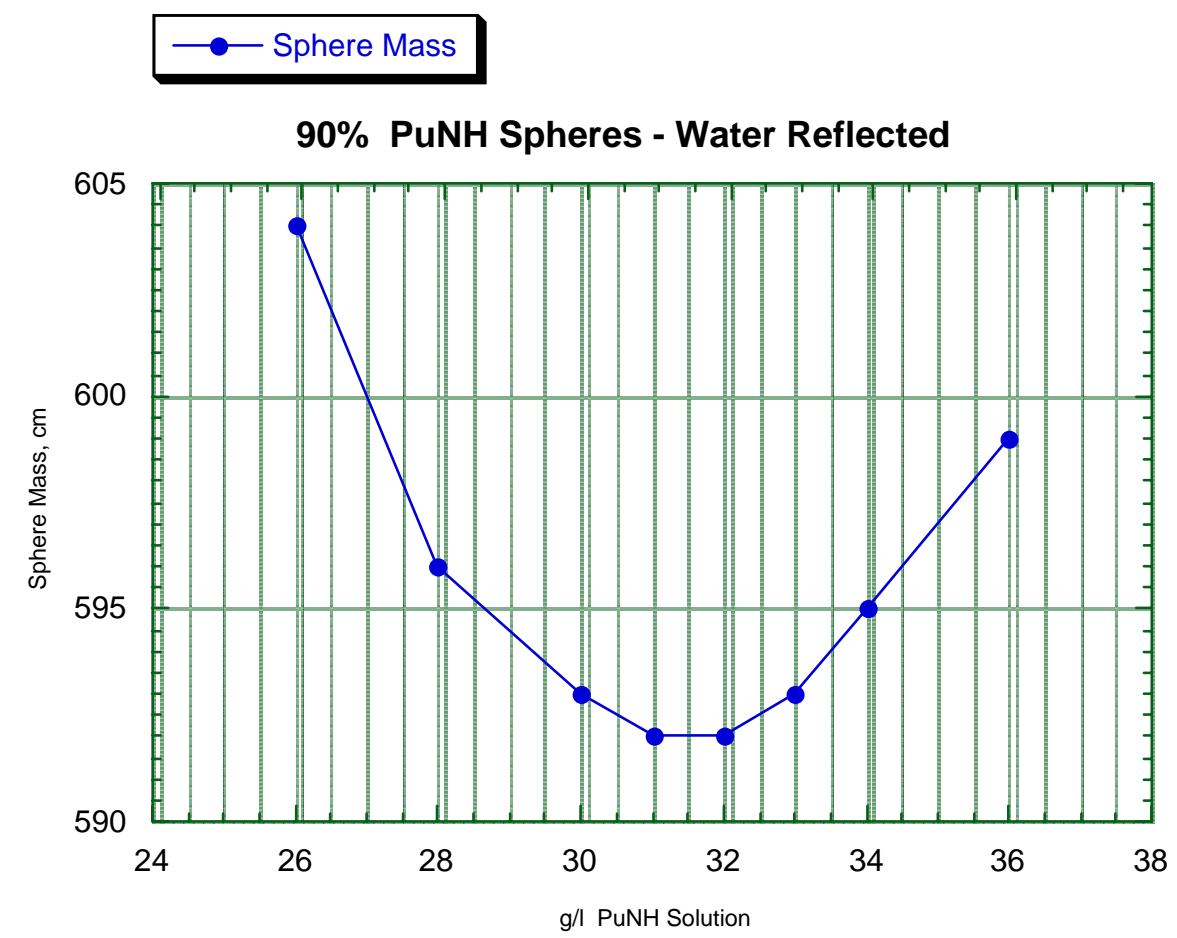

Fig. D.8. Mass vs density for $90 \%$ enriched $\mathrm{PuNH}-\mathrm{H}_{2} \mathrm{O}$ spheres.

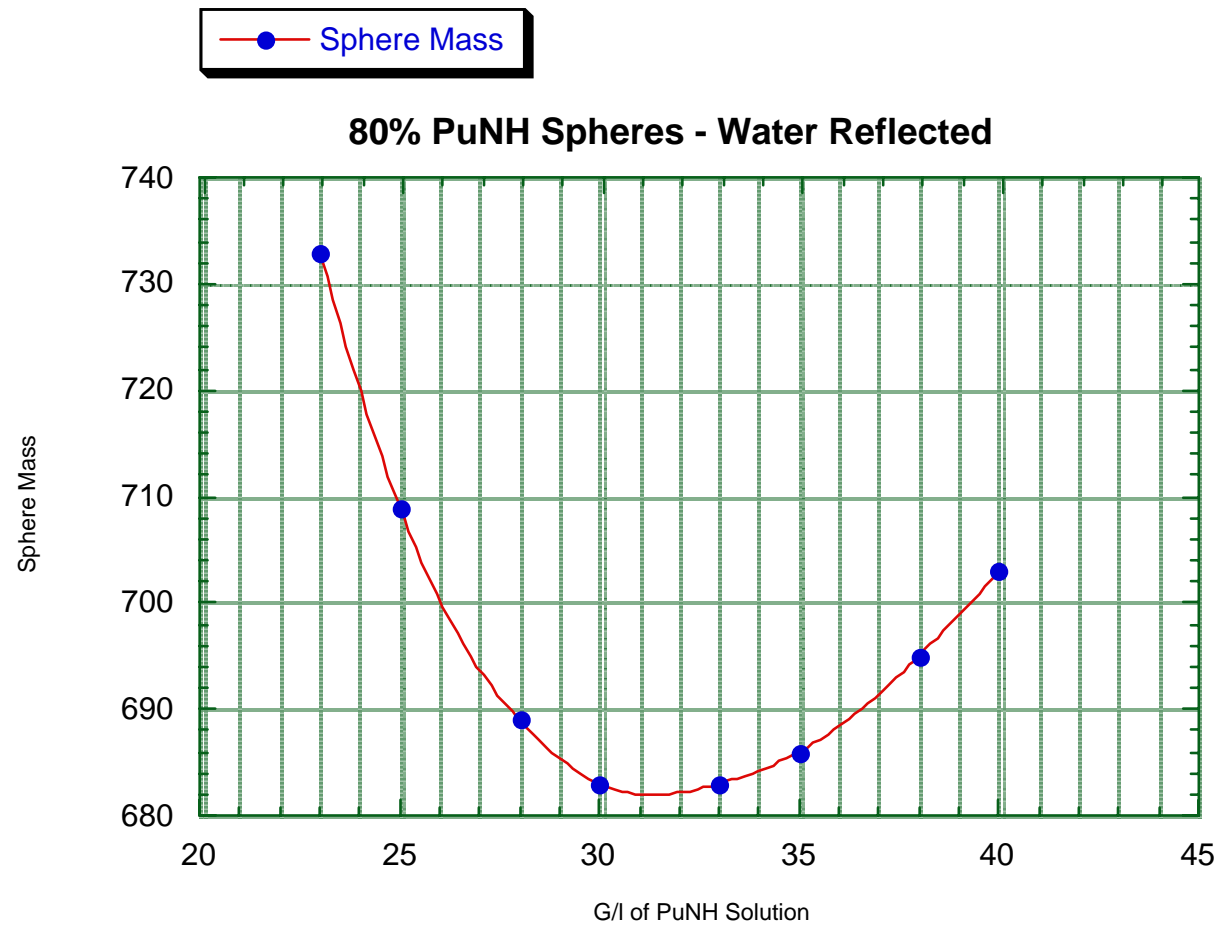

Fig. D.9. Mass vs density for $80 \%$ enriched $\mathrm{PuNH}-\mathrm{H}_{2} \mathrm{O}$ spheres. 


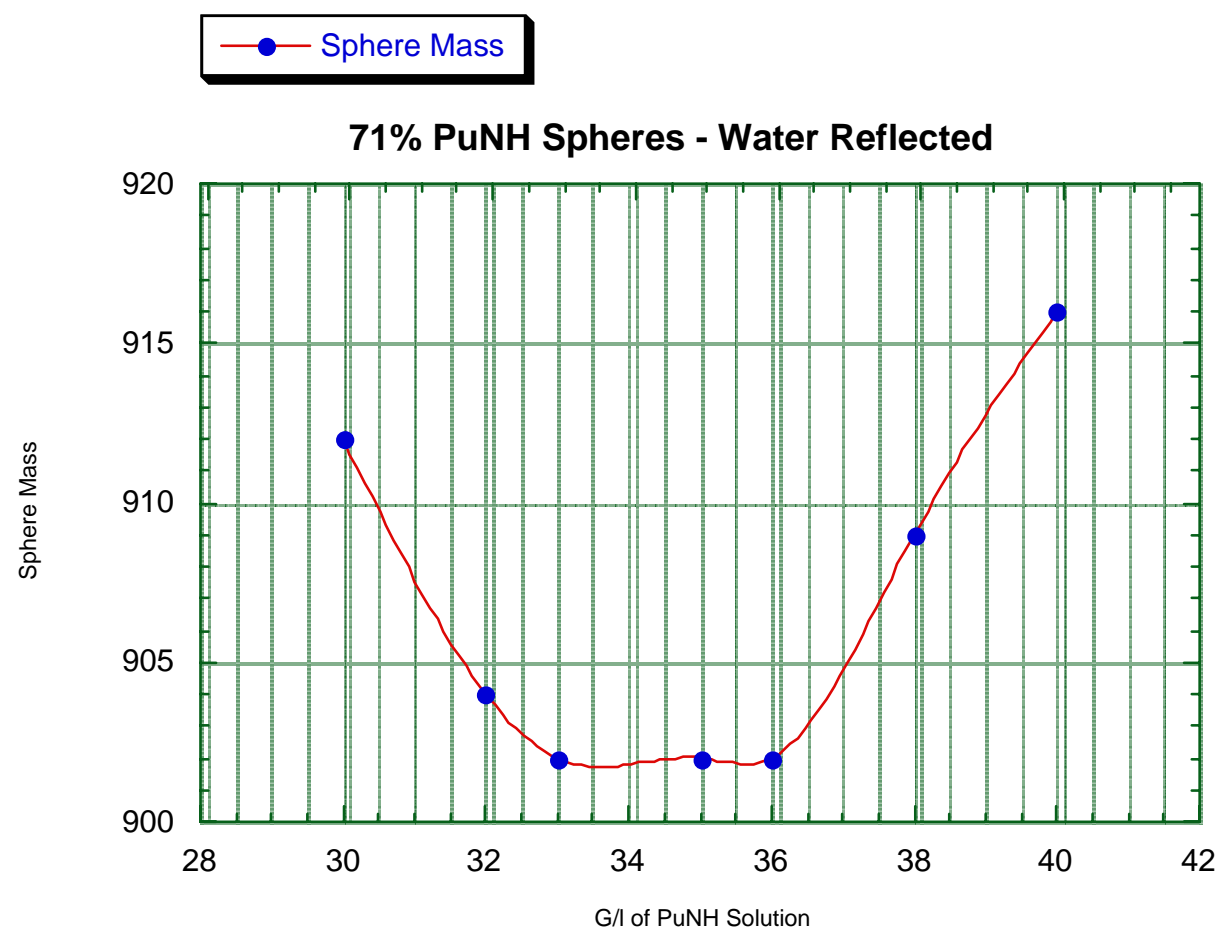

Fig. D.10. Mass vs density for $71 \%$ enriched $\mathrm{PuNH}-\mathrm{H}_{2} \mathrm{O}$ spheres. 


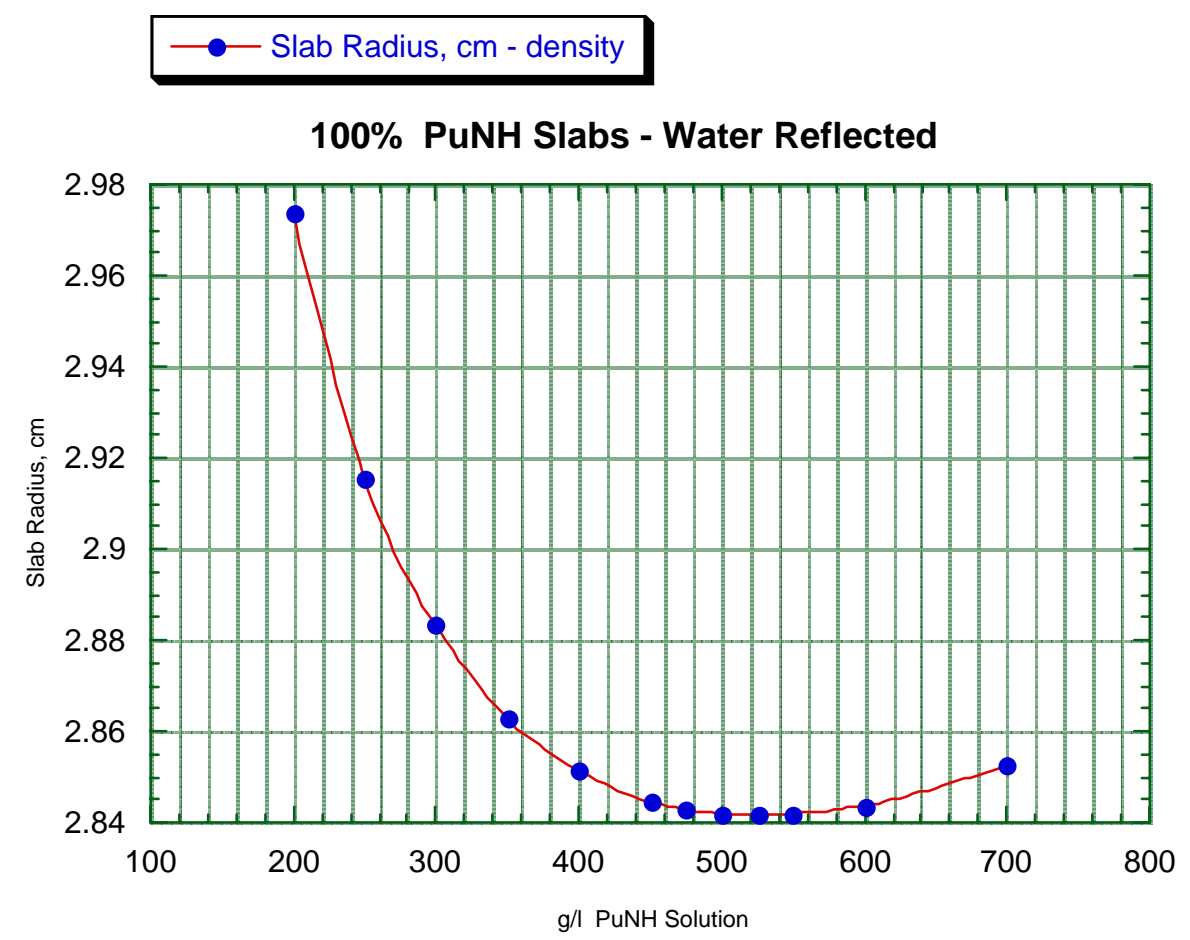

Fig. D.11. Radius vs density for $100 \%$ enriched $\mathrm{PuNH}-\mathrm{H}_{2} \mathrm{O}$ slabs.

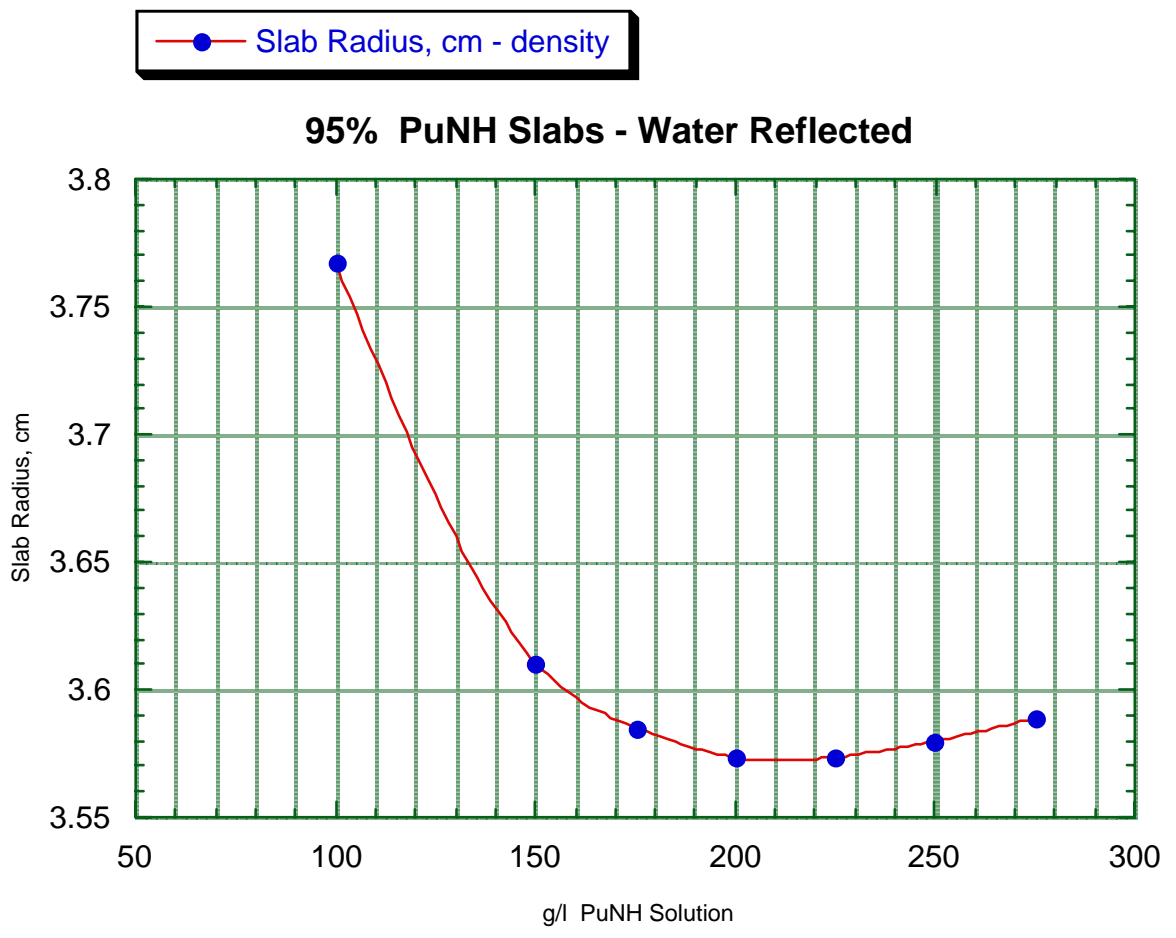

Fig. D.12. Radius vs density for $95 \%$ enriched $\mathrm{PuNH}-\mathrm{H}_{2} \mathrm{O}$ slabs. 


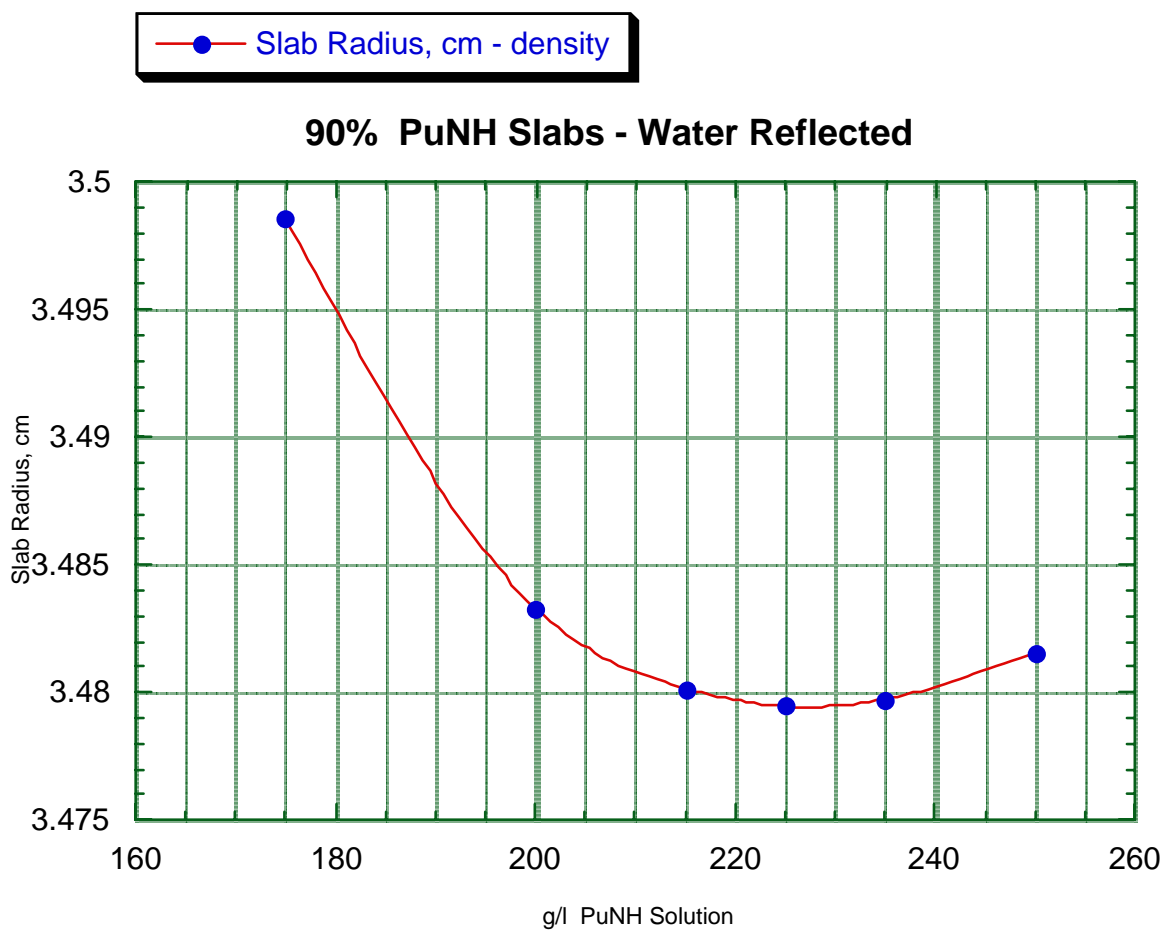

Fig. D.13. Radius vs density for $90 \%$ enriched $\mathrm{PuNH}-\mathrm{H}_{2} \mathrm{O}$ slabs.

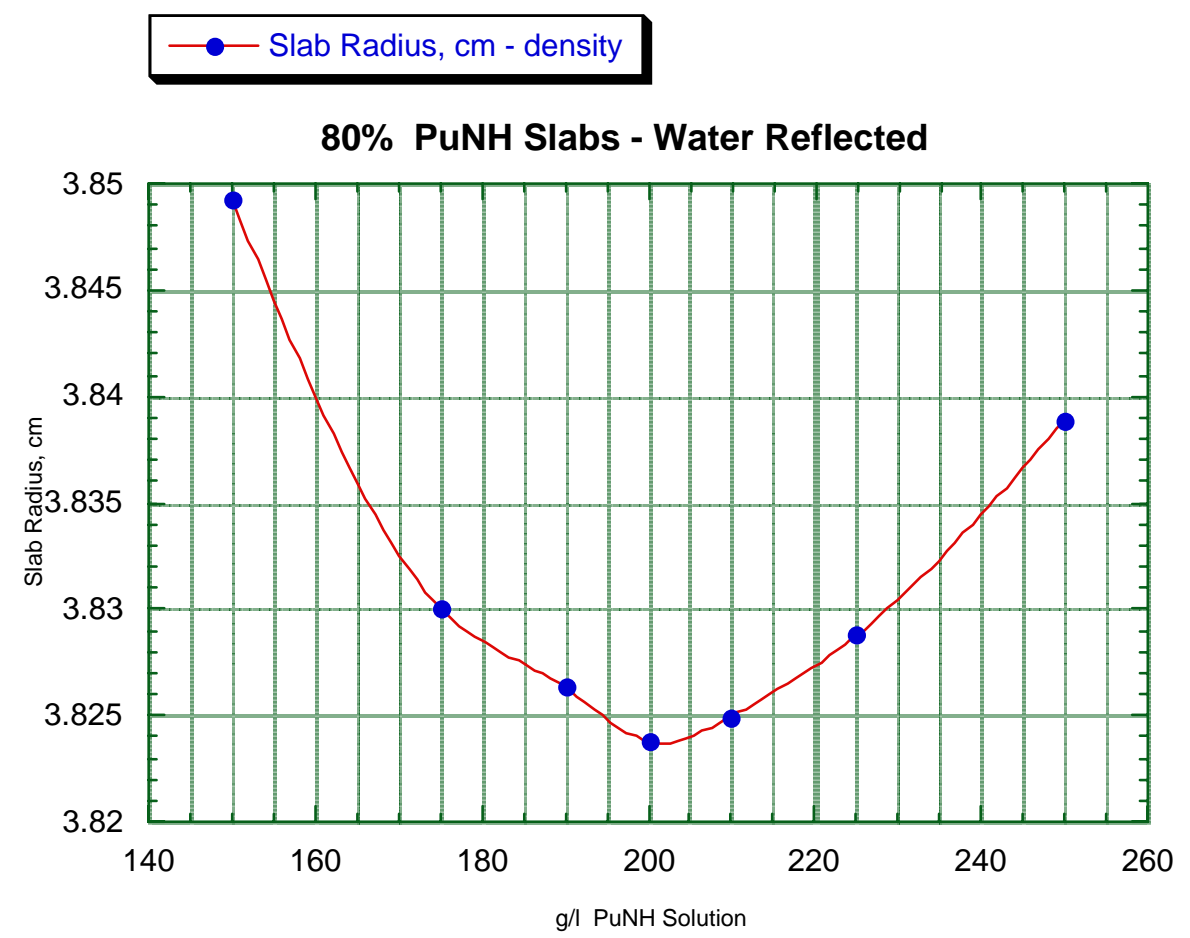

Fig. D.14. Radius vs density for $80 \%$ enriched $\mathrm{PuNH}-\mathrm{H}_{2} \mathrm{O}$ slabs. 


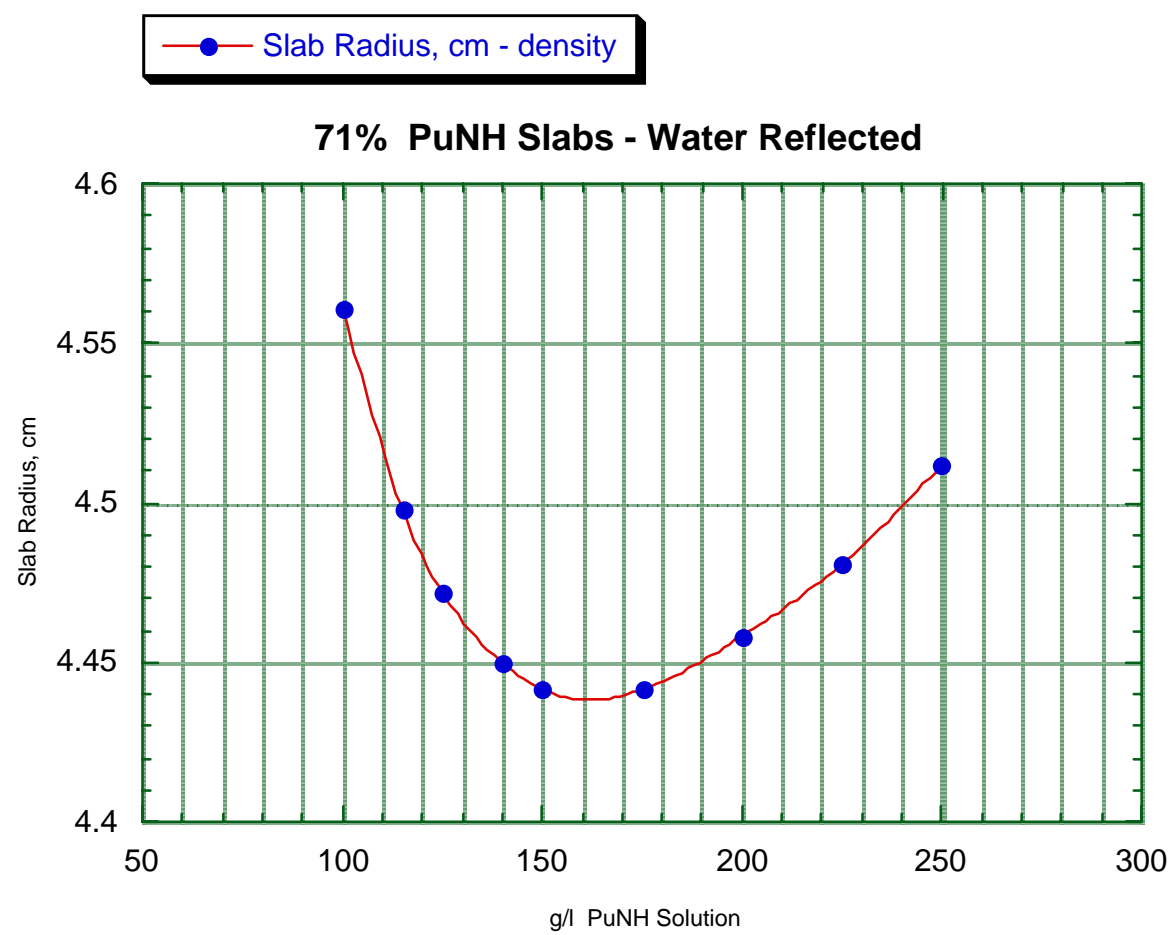

Fig. D.15. Radius vs density for $71 \%$ enriched $\mathrm{PuNH}-\mathrm{H}_{2} \mathrm{O}$ slabs. 


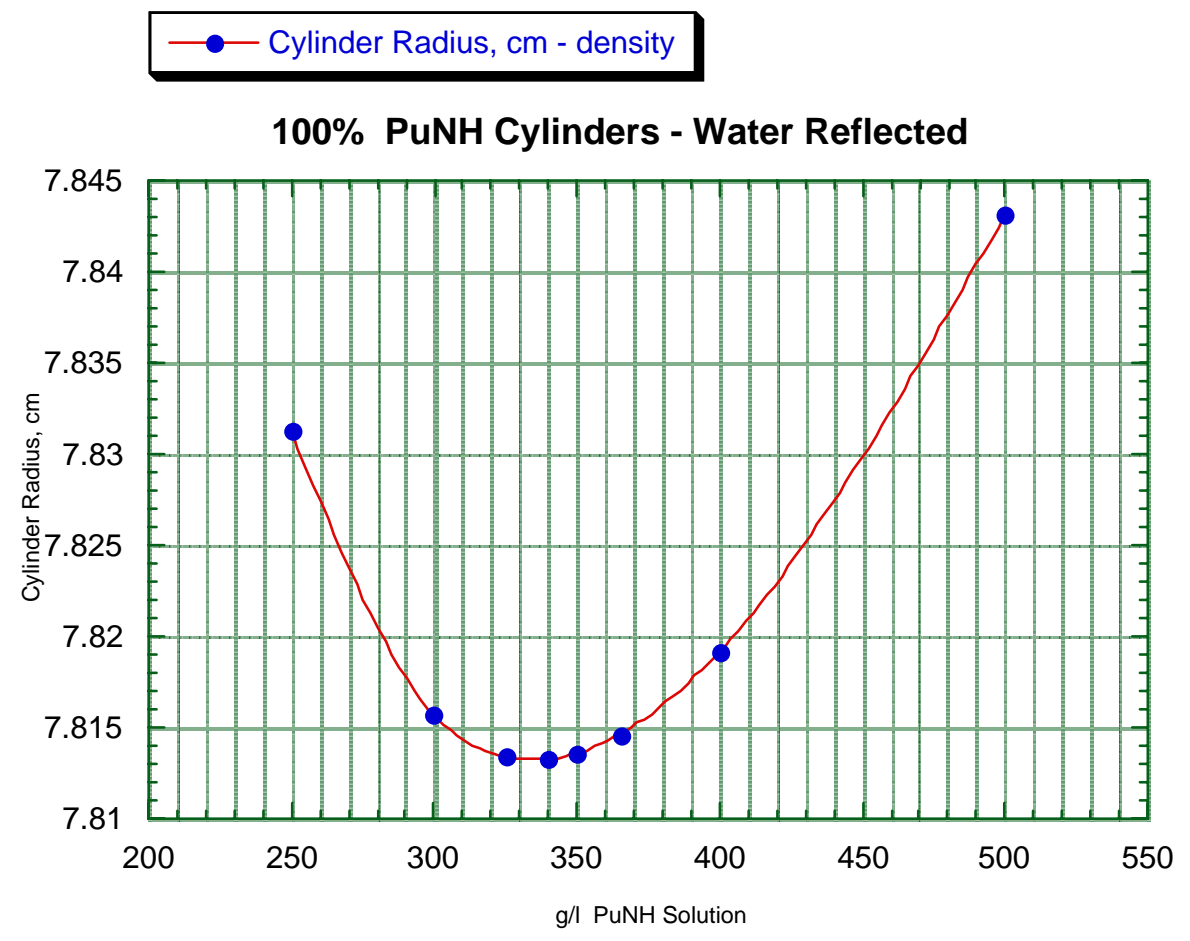

Fig. D.16. Radius vs density for $100 \%$ enriched $\mathrm{PuNH}-\mathrm{H}_{2} \mathrm{O}$ cylinders.

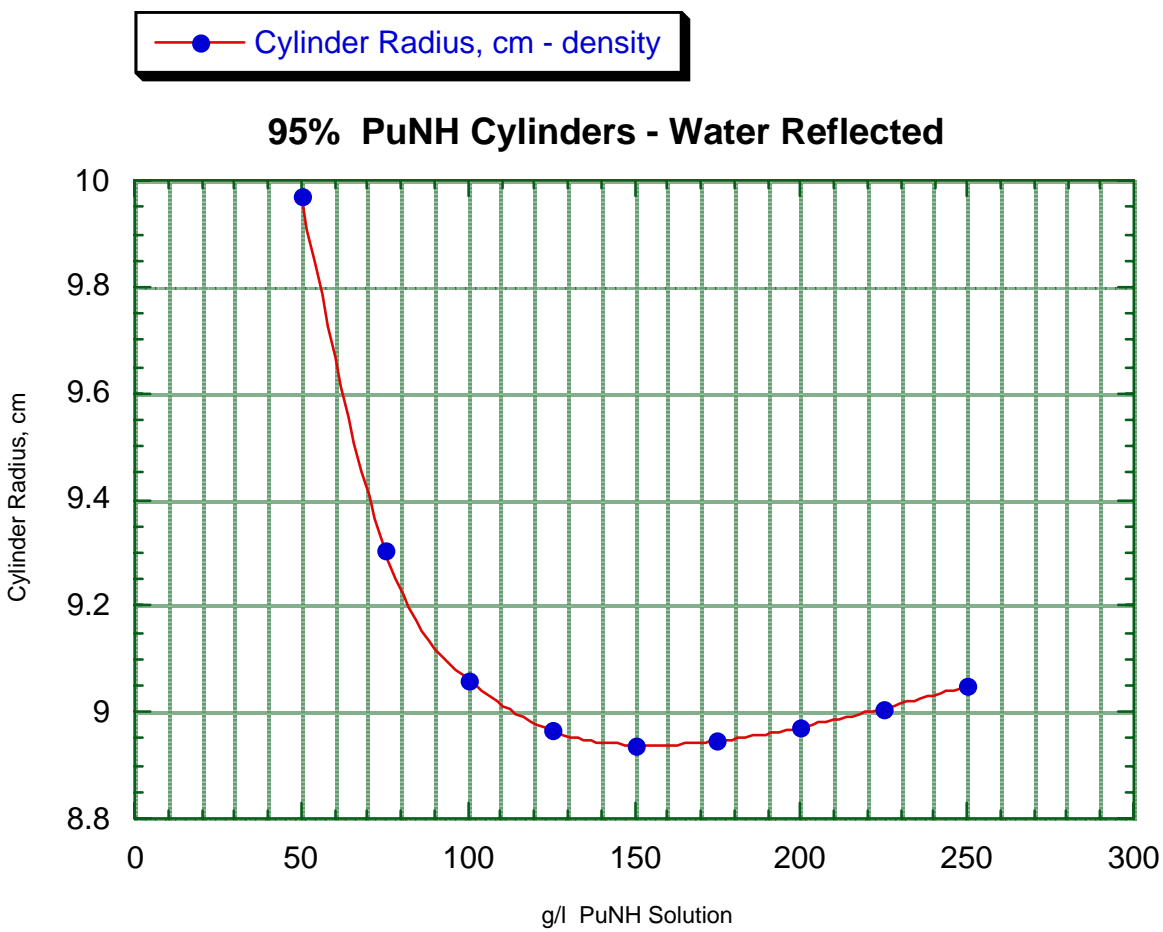

Fig. D.17. Radius vs density for $95 \%$ enriched $\mathrm{PuNH}-\mathrm{H}_{2} \mathrm{O}$ cylinders. 


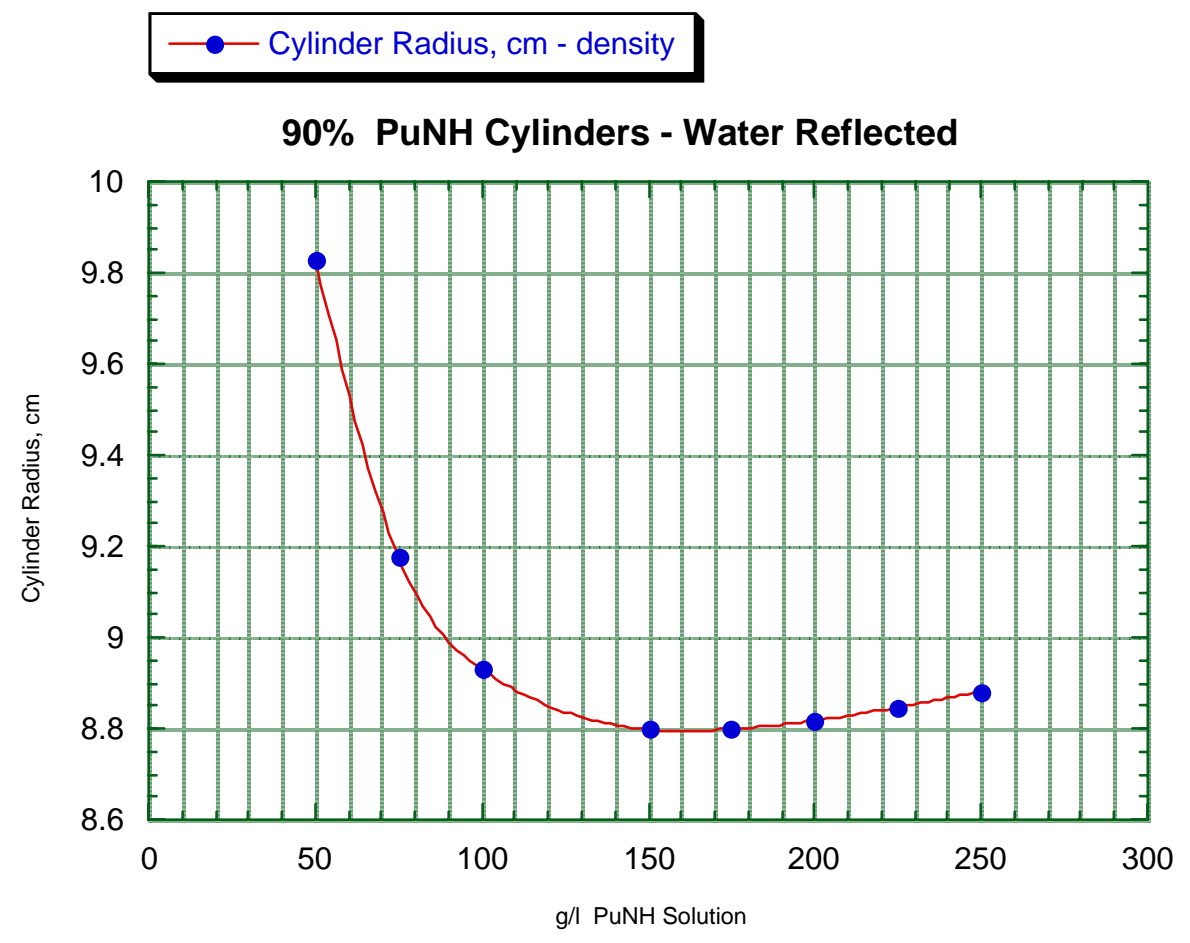

Fig. D.18. Radius vs density for $90 \%$ enriched $\mathrm{PuNH}-\mathrm{H}_{2} \mathrm{O}$ cylinders.

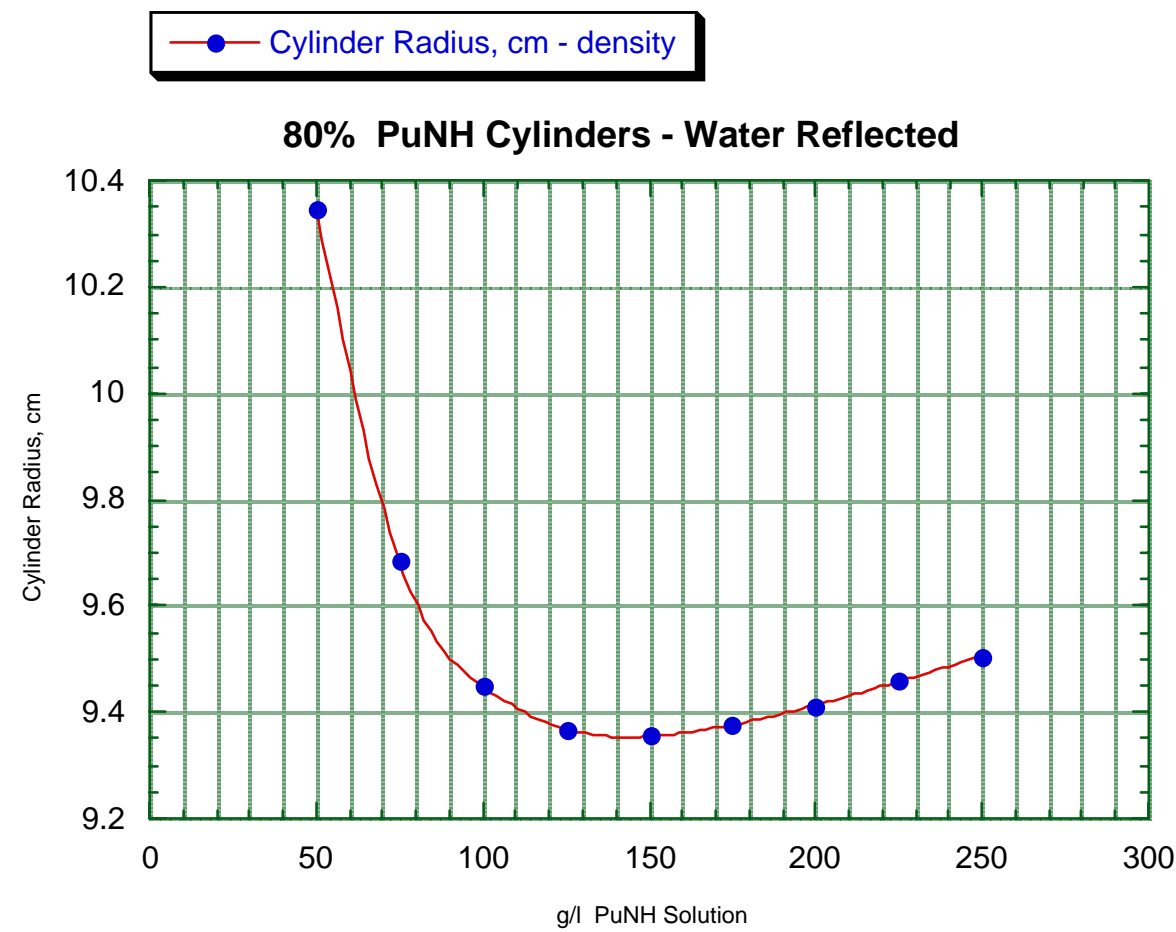

Fig. D.19. Radius vs density for $80 \%$ enriched $\mathrm{PuNH}-\mathrm{H}_{2} \mathrm{O}$ cylinders. 


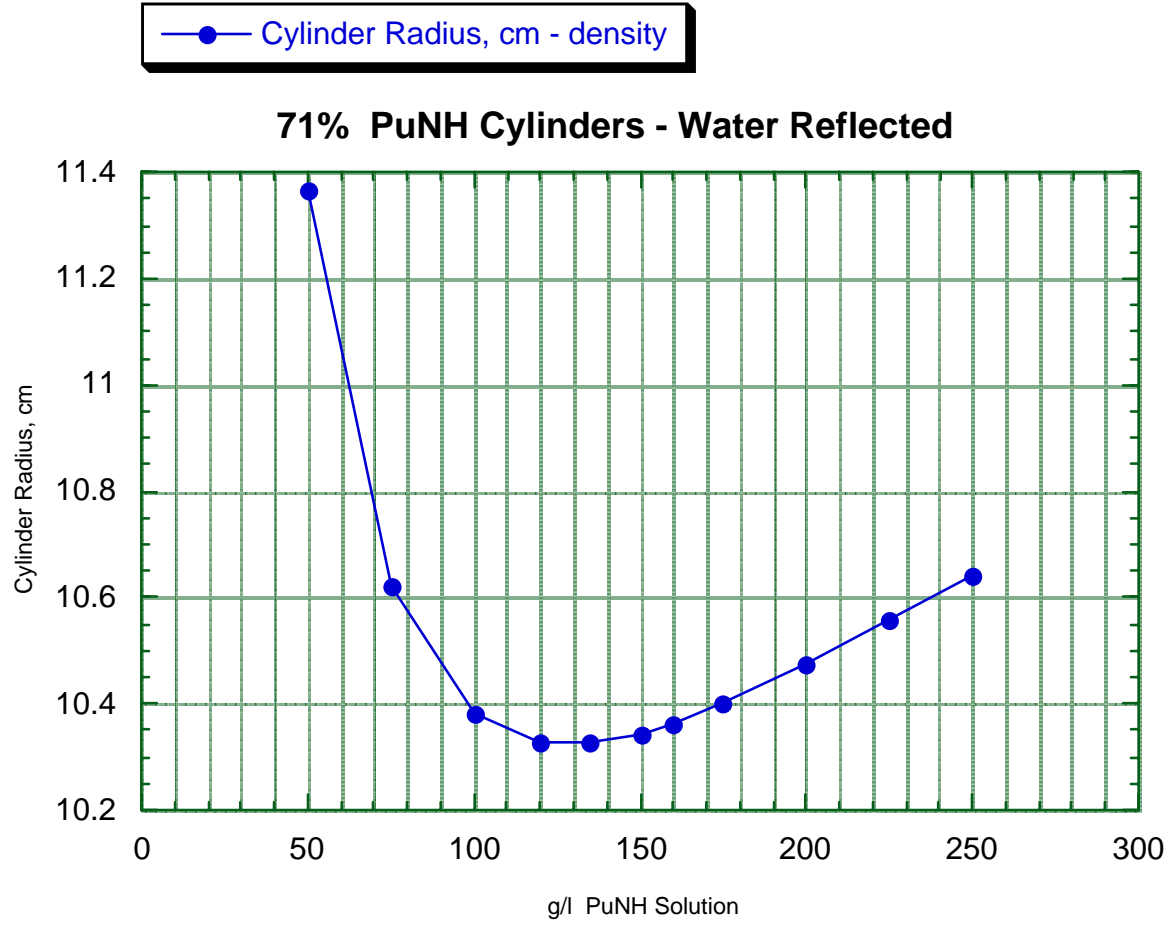

Fig. D.20. Radius vs density for $71 \%$ enriched $\mathrm{PuNH}-\mathrm{H}_{2} \mathrm{O}$ cylinders. 
ORNL/TM-2003/211

\section{INTERNAL DISTRIBUTION}

1. M. E. Dunn

2. P. B. Fox

3. S. Goluoglu

4. J. N. Herndon

5. D. J. Hill

6. D. F. Hollenbach

7. C. M. Hopper

8. D. E. Mueller
9. C. V. Parks

10. L. M. Petrie

11. B. T. Rearden

12. J. E. Rushton

13. J. C. Wagner

14. R. M. Westfall

15. OSIC-RC, OSTI, CRL

\section{EXTERNAL DISTRIBUTION}

16. Joon Gi Ahn, Korea Power Engineering Company, Inc., 150 Duckjin-dong, Yusong-gu, Daejeon, Korea, 305-353

17. Richard E. Anderson, Los Alamos National Laboratory, P.O. Box 1663, Los Alamos, NM 87545

18. Michaele Brady-Raap, P.O. Box 999/K8-34, Richland, WA 99352

19. Blair Briggs, Idaho National Laboratory, STC 654-EROB, MS-3860, 2525 N. Fremont Ave., P.O. Box 1625, Idaho Falls, ID 83415

20. Vladimir Chrapciak, VUJE Trnava, Inc., Engineering, Design, and Research Organization, Okruzna 5, 91864 Trnava, Slovakia

21. David Erickson, Fluor Government Group, P.O. Box 1050, MSIN E6-17, Richland, WA 99352-1050

22. J. R. Felty, U.S. Department of Energy, NA-117/Germantown Building, 1000 Independence Ave., S.W., Washington, DC 20585-1290

23. Ivon Fergus, U.S. Department of Energy, OA-40/Germantown Building, 1000 Independence Ave., S.W., Washington, DC 20585-1290

24. Edward Fujita, Argonne National Laboratory, 9700 S. Cass Avenue, Argonne, IL 60439

25. Adolf Garcia, Idaho National Engineering and Environmental Laboratory, 2525 North Fremont Ave., Idaho Falls, ID 83401

26. Bernhard Gmal, Gesellschaft fuer Anlagen und Reaktorsicherheit, Postfach 1328 D-85739 Garching, Germany

27. Nigel (Jim) Gulliford, BNFL Rutherford House, Risley, Warrington, WA3 6AS, United Kingdom

28. Neil Harris, BNFL Rutherford House, Risley, Warrington, WA3 6AS, United Kingdom

29. Liem Peng Hong, NAIS Co., Inc., 416 Muramatsu, Tokai-mura, Noka-gun, Ibaraki-ken 319-1112, Japan

30. Gabor Hordósy, KFKI Atomic Energy Research Institute, Reactor Analysis Dept., P.O. Box 49, H-1525 Budapest, Hungary

31. Neuber Jens-Christian, Framatome-ANP GmbH, Keiserleistrasse 29, Dept. NGPM5, P.O. Box 100551, D-63010 Offenbach, Germany

32. Ludmila Markova, Ustav Jaderneho Vyzkumu Rez, Theoretical Reactor Physics, Nuclear Research Institute, 25068 REZ, Czech Republic

33. Jerry McKamy, U.S. Department of Energy, NA-117/Germantown Building, 1000 Independence Ave., S.W., Washington, DC 20585-1290 
34. Thomas McLaughlin, Los Alamos National Laboratory, P.O. Box 1663, EHS-6, MS F691, Los Alamos, NM 87545

35. Dennis Mennerdahl, E. Mennerdahl Systems, Starvägen 12, S-183 57 Taby, Sweden

36. Susumu Mitake, Japan Nuclear Energy Safety Org., 3-20 Toranomon 4-chome, Minatoku, Tokyo, Japan

37. Yoshinori Miyoshi, Dept. of Fuel Cycle Safety Research, Japan Atomic Energy Research Institute, 2-4 Shirakata Shirane, Tokai-mura, Ibaraki-ken, 319-1195 Japan

38. James Morman, Argonne National Laboratory, 9700 S. Cass Avenue, Argonne, IL 60439

39. Yoshitaka Naito, NAIS Co., Inc., 416 Muramatsu, Toaki-mura, Naka-gun, Ibaraki-ken 319-1112, Japan

40. Claes Nordborg, OECD Nuclear Energy Agency, Le Seine Saint-Germain, 12 Boulevard des Iles, F-92130 Issy-les-Moulineaux, France

41. Ali Nouri, IRSN, 77-83 Avenue du Général de Gaulle, 92140 Clamart, France

42. Hiroshi Okuno, Department of Fuel Cycle, Safety Research, JAERI, 2-4 Shirakata-Shirane, 319-1195 Tokai-mura, Naka-gun, Ibaraki-ken, Japan

43. Ingo Reiche, Bundesamt fuer Strahlenschutz, Willi Brandt Str. 5, D-38226 Salzgitter, Germany

44. Tom Reilly, 1800 Robinson Drive, North Augusta, SC 29841

45. Veronique Rouyer, IRSN/DSU/SEC, BP 17, F-92265 Fontenay Aux Roses Cedex, France

46. Yevgeniy Rozhikhin, Institute of Physics and Power Engineering, Obninsk, Kaluga Region, Russian Federation

47. Yolanda Rugama, Nuclear Data Services, OECD NEA Data Bank, 12 Bd des Iles, 92130 Issy-les-Moulineaux, France

48. Vojtěch Rypar, Nuclear Research Institute Řež, plc 25068 Řež, Prague, Czech Republic

49. Enrico Sartori, OECD NEA Data Bank, 12 Bd des Iles, 92130 Issy-les-Moulineax, France

50. M. A. Thompson, U.S. Department of Energy, NA-117/Germantown Building, 1000 Independence Ave., S.W., Washington, DC 20585-1290

51. Hans Toffer, FFS, 1200 Jadwin Avenue, MSIN A0-26, P.O. Box 1050, Richland, WA 99352-1050

52. Anatolia Tsiboulia, Institute of Physics and Power Engineering, Fiziko-Energiticheskij Inst., 1, Bondarenko Square, 249020 Obninsk, Russian Federation

53. Wolf-Jürgen Weber, Gesellschaft fuer Anlagen und Reaktorsicherheit, Forschungsgelaende, Postfach 1328, D-85748 Garching, Germany

54. Robert E. Wilson, U.S. Department of Energy, EM-22, 1000 Independence Ave., S.W., Washington, DC 20585

55. Carl J. Withee, U.S. Nuclear Regulatory Commission, 11555 Rockville Pike, OWFN 13 H3 13 D13 NMSS/SFPO/TRB, Rockville, MD 20852-2738 